\title{
Notes on currently accepted species of Colletotrichum
}

\section{Jayawardena $\mathrm{RS}^{1,2}$, Hyde $\mathrm{KD}^{2,3}$, Damm $\mathrm{U}^{4}$, Cai $\mathrm{L}^{5}$, Liu $\mathrm{M}^{1}$, Li XH $\mathbf{X H}^{1}$, Zhang $\mathbf{W}^{1}$, Zhao $\mathrm{WS}^{6}$ and Yan $\mathrm{JY}^{1, *}$}

${ }^{I}$ Institute of Plant and Environment Protection, Beijing Academy of Agriculture and Forestry Sciences, Beijing 100097, People's Republic of China

${ }^{2}$ Center of Excellence in Fungal Research, Mae Fah Luang University, Chiang Rai 57100, Thailand

${ }^{3}$ Key Laboratory for Plant Biodiversity and Biogeography of East Asia (KLPB), Kunming Institute of Botany, Chinese Academy of Science, Kunming 650201, Yunnan, China

${ }^{4}$ Senckenberg Museum of Natural History Görlitz, PF 300 154, 02806 Görlitz, Germany

${ }^{5}$ State Key Laboratory of Mycology, Institute of Microbiology, Chinese Academy of Sciences, Beijing, 100101, China

${ }^{6}$ Department of Plant Pathology, College of Plant Protection, China Agricultural University, Beijing 100193, China.

Jayawardena RS, Hyde KD, Damm U, Cai L, Liu M, Li XH, Zhang W, Zhao WS, Yan JY 2016 Notes on currently accepted species of Colletotrichum. Mycosphere 7(8) 1192-1260, Doi $10.5943 /$ mycosphere/si/2c/9

\begin{abstract}
Colletotrichum is an economically important plant pathogenic genus worldwide, but can also have endophytic or saprobic lifestyles. The genus has undergone numerous revisions in the past decades with the addition, typification and synonymy of many species. In this study, we provide an account of the 190 currently accepted species, one doubtful species and one excluded species that have molecular data. Species are listed alphabetically and annotated with their habit, host and geographic distribution, phylogenetic position, their sexual morphs and uses (if there are any known). There are eleven species complexes in Colletotrichum and 23 singleton species. The main characters of each species complex are detailed with illustrations. Phylogenetic trees are provided for the whole genus and each species complex. Genes and combination of genes that can be used for identification of the species complexes are suggested. Specific genes that can be used in species identification are given when possible.
\end{abstract}

Key words - Glomerellaceae - nomenclature - phylogeny - species complex - taxonomy

\section{Introduction}

The genus Colletotrichum was introduced by Corda (1831) and belongs to the family Glomerellaceae (Glomerellales, Sordariomycetes), and is the sole member of this family (Réblová et al. 2011, Maharachchikumbura et al. 2015, 2016). Species of this genus are important pathogens, some are endophytes as well as saprobes (Cannon et al. 2012, Hyde et al. 2014, Jayawardena et al. 2016a).

At the time of the first monographic treatment of Colletotrichum (von Arx 1957), around 750 names existed (Cannon et al. 2012). Von Arx (1957) reduced this to 11 taxa based on morphological characters. Sutton (1980) accepted 22 species, while Sutton (1992) accepted 39 species based on morphological and cultural characteristics. Hyde et al. (2009b) provided the first comprehensive overview of this genus with 66 names in common use and 19 doubtful names and also highlighted the need to revise this genus by using molecular methods (Hyde et al. 2009a). This 
was the beginning of the still ongoing revision of the genus based on multi-locus sequence data in which several species were revised and typified or newly described and several species complexes were detected (Cannon et al. 2012, Damm et al. 2009, 2012a, b, 2013, 2014, Weir et al. 2012, Crouch et al. 2009a, 2014, Hyde et al. 2014, Liu et al. 2015a). Index Fungorum (2016) lists 820 epithets (www.indexfungorum.org; accesses $7^{\text {th }}$ August 2016) under Colletotrichum, but only less than 200 names are currently accepted (Hyde et al. 2014).

Misidentification of Colletotrichum species is a frequent mistake that happens due to few distinctive morphological characters available for identification. Misunderstanding of their host specific nature has also lead to misapplication and misidentification of species (Cannon et al. 2012). Many older Colletotrichum names lack type specimens and authentic living strains for molecular analysis. This tends to get in the way of reconstructing a natural classification system for Colletotrichum (Cai et al. 2009, Hyde et al. 2009a,b, Cannon et al. 2012). Epi- or neotypes of the Colletotrichum species are being designated to preseve the current application of names according to the International Code of Nomenclature for Algae, Fungi and Plants (Hawksworth 2011). Before assigning an epitype for a species, the fresh collection needs to be carefully compared to the type material, if preserved. An epitype should have morphological characteristics similar to the holotype or the original description and originate from the same geographical region and host (Ariyawansa et al. 2014). Once an epitype is designated, questions of species diversity of this genus can be addressed on the basis of the DNA sequence data of the ex-epitype strain.

Currently, researchers strongly recommend the application of a polyphasic approach, including the analysis of geographical, ecological, morphological and genetic data in order to establish a natural classification system for the genus Colletotrichum (Cai et al. 2009). For species delimitation within this genus, phylogentic analysis based on concatenated loci and the application of the Genealogical Concordance Phylogenetic Species Recognition (GCPSR) have proven to be poverful tools (Cannon et al. 2012, Liu et al. 2016). Coalescent-based species delimination methods can be used to infer the dynamic of divergence, evolutionary process and the relationships among species (McCormack et al. 2009, Liu et al. 2016).

Most of the species in this genus are important phytopathogens, while some are endophytes and saprobes. The basis of the current study for the lifestyles is that if a fungus was isolated from a diseased tissue (fruit, leaf and stem) it is referred to as a pathogen; if a fungus was isolated from a healthy tissue it is considered as an endophyte and if a fungus was isolated from a dead plant matter is considered as a saprobe.

This study uses Cannon et al. (2012) as the starting point for the accepted species, as well as published records since that study. An overview of the currently accepted species in the genus with their hosts, geographic distribution, phylogenetic position, sexual morphs as well as their uses (if there are any known) is provided. The main characters of each species complex are illustrated. Phylogenetic trees are provided for the whole genus and the species complexes. Genes necessary to distinguish the species within the different species complexes are also provided when possible.

\section{Material and Methods}

This study deals with the species included in Cannon et al. (2012) and newly described species after this publication. The USDA fungal databases (Farr \& Rossman 2016) have been used in order to gather information on host association and geographic distribution. Additional, new disease reports were also included.

Morphology

Conidial and appresorial characteres of different species complexes were focused in this study. Photo plates were created from the photos provided by U. Damm and F. Liu. Line diagrams were drawn where necessary, using transparent drawing papers and drawing pens.

Phylogenetic Analysis

Actin (ACT), $\beta$-tubulin2 (TUB2), chitin synthase (CHS-1), DNA lyase (Apn2), glyceraldehyde-3-phosphate dehydrogenase (GAPDH), glutamine synthetase (GS), histone 3 
(HIS3), internal transcribed spacers (ITS), manganese-superoxide dismutase (SOD2), mating type gene (Mat1), and Apn2/MAT1GS (Ap/Mat) sequences of each accepted species were download, if available, from NCBI GenBank (https://www.ncbi.nlm.nih.gov/genbank/). A backbone phylogenetic tree of the whole genus and separate phylogenetic trees of the species complexes were constructed.

Single gene regions were aligned using Clustal X1.81 (Thompson et al. 1997) and combined using BioEdit v.7.0.9.0 (Hall 1999). Further alignment of the sequences was done using default settings of MAFFT v.7 (Katoh \& Toh 2008; http://mafft.cbrc.jp/alignment/server/) and manual adjustment was conducted using BioEdit where necessary. Maximum Parsimony analysis (MP) was performed using PAUP (Phylogenetic Analysis Using Parsimony) v. $4.0 b 10$ (Swofford 2002) to obtain the most parsimonious trees. Gaps were treated as missing data and ambiguously aligned regions were excluded. Trees were inferred using the heuristic search option with Tree Bisection Reconnection branch swapping and 1000 random sequence additions. Maxtrees were set up to 5000, branches of zero length were collapsed and all multiple parsimonious trees were saved. Descriptive tree statistics for parsimony (tree length, consistency index, retention index, rescaled consistency index, and homoplasy index) were calculated for trees generated under different optimality criteria. The robustness of the most parsimonious trees was evaluated by 1000 bootstrap replications resulting from maximum parsimony analysis (Hillis \& Bull 1993). Kishino-Hasegawa tests (Kishino \& Hasegawa 1989) were performed in order to determine whether trees were significantly different.

A maximum likelihood analysis was performed for the whole genus in raxmlGUIv.0.9b2 (Silvestro \& Michalak 2010). Rapid bootstrapping with 1000 non parametric bootstrapping iterations, using the general time reversible model (GTR) with a discrete gamma distribution, was set as the search strategy.

Bayesian inference (BI) was used in addition to construct the phylogenies using Mr. Bayes v.3.1.2 (Ronquist et al. 2003). MrModeltest v. 2.3 (Nylander 2004) was used to carry out statistical selection of best-fit model of nucleotide substitution and was incorporated into the analysis. Six simultaneous Markov chains were run for 1000000 generations and trees were sampled every $100^{\text {th }}$ generation. The 2000 trees representing the burn-in phase of the analyses, were discarded and the remaining 8000 trees used for calculating posterior probabilities (PP) in the majority rule consensus tree. The fungal strains that were used for this study are listed in Table 1 with details of type cultures and sequence data.

\section{Results and Discussion}

The Colletotrichum names that are currently accepted are listed alphabetically below, with notes of the authorities and publication details, habits, hosts, geographical distribution, uses and sexual morphs (if there are any) as well as systematic position. The 190 accepted names are also listed in Table 1. Liu et al. (2016) emphazied on the importance of using polyphasic approaches such as genealogical concordance phylogenetic species recognition (GCPSR) and coalescent methods when describing new species in morphologically conserved genera. A backbone tree of the genus Colletotrichum comprising 189 species using five gene regions have been constructed (Fig. 1). However, several species have been excluded from this analysis due to the lack of sequences. All the species complexes can be distinguished effectively from each other by using ITS sequence data alone. Species within species complexes can be resolved with the use of additional genes are mentioned with the different complexes.

\section{Acutatum species complex}

This species complex consists of 34 species that include $C$. acutatum and its close relatives. Members of this species complex often cause fruit rots (Damm et al. 2012b). Most species within this complex have conidia with at least one acute end (Fig. 2) (Damm et al. 2012b). A combined gene analysis for this complex using ITS, GAPDH, CHS-1, HIS3, ACT and TUB2 sequences is 
given in Fig. 3. In order to differentiate species within this complex effectively, use of both TUB2 and GAPDH are recommended (Damm et al. 2012b).

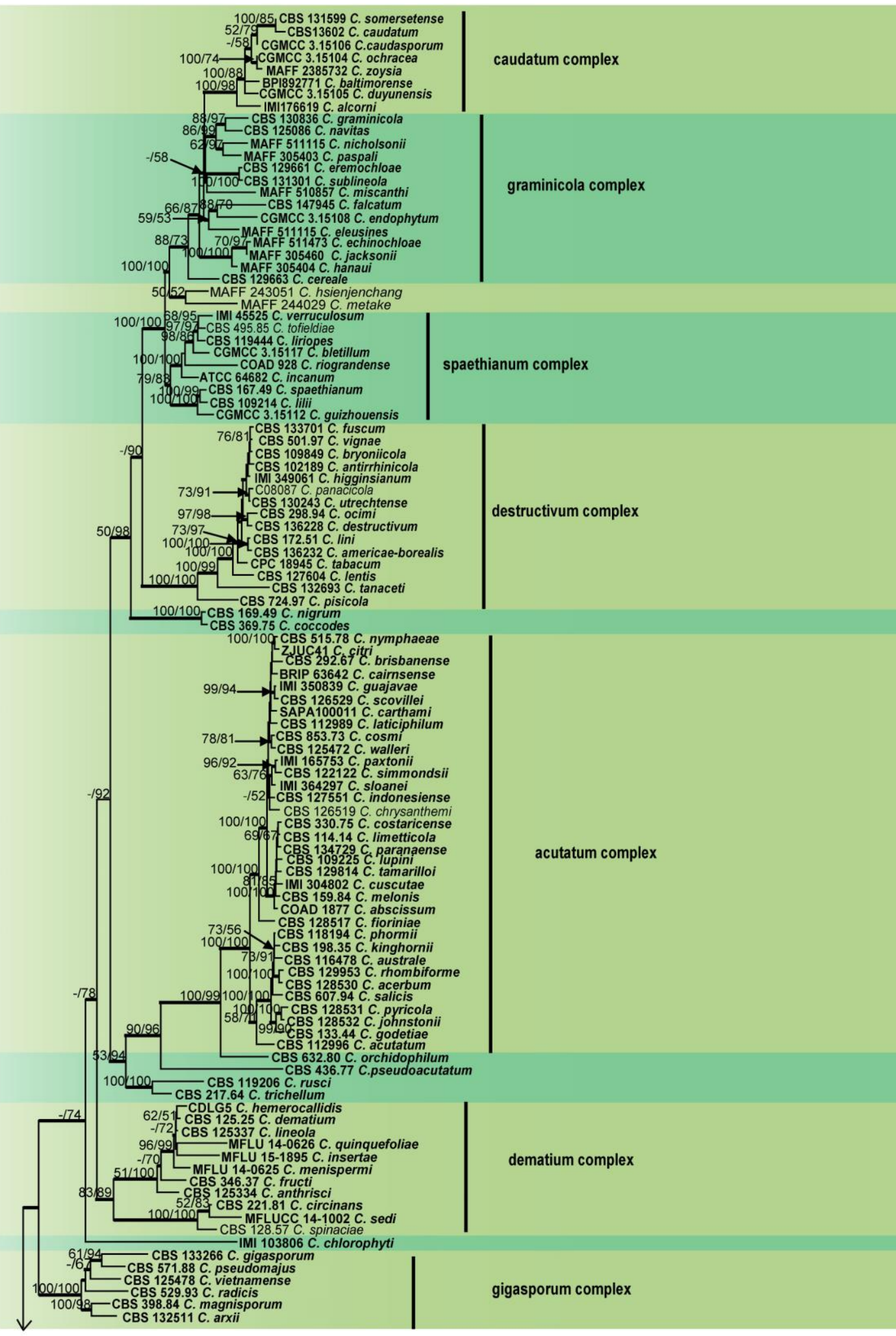

Fig. 1 One of the 100 most parsimonious trees obtained from a heuristic search of combined ITS, GAPDH, CHS-1, ACT and TUB2 sequence data of the genus Colletotrichum. Parsimony and likelihood bootstrap support values $\geq 50 \%$ are indicated at the nodes and branches with Bayesian posterior probabilities above 0.80 are given in bold. The ex-type strains are in bold. The tree is rooted with Monilochaetes infuscans CBS 869.96 


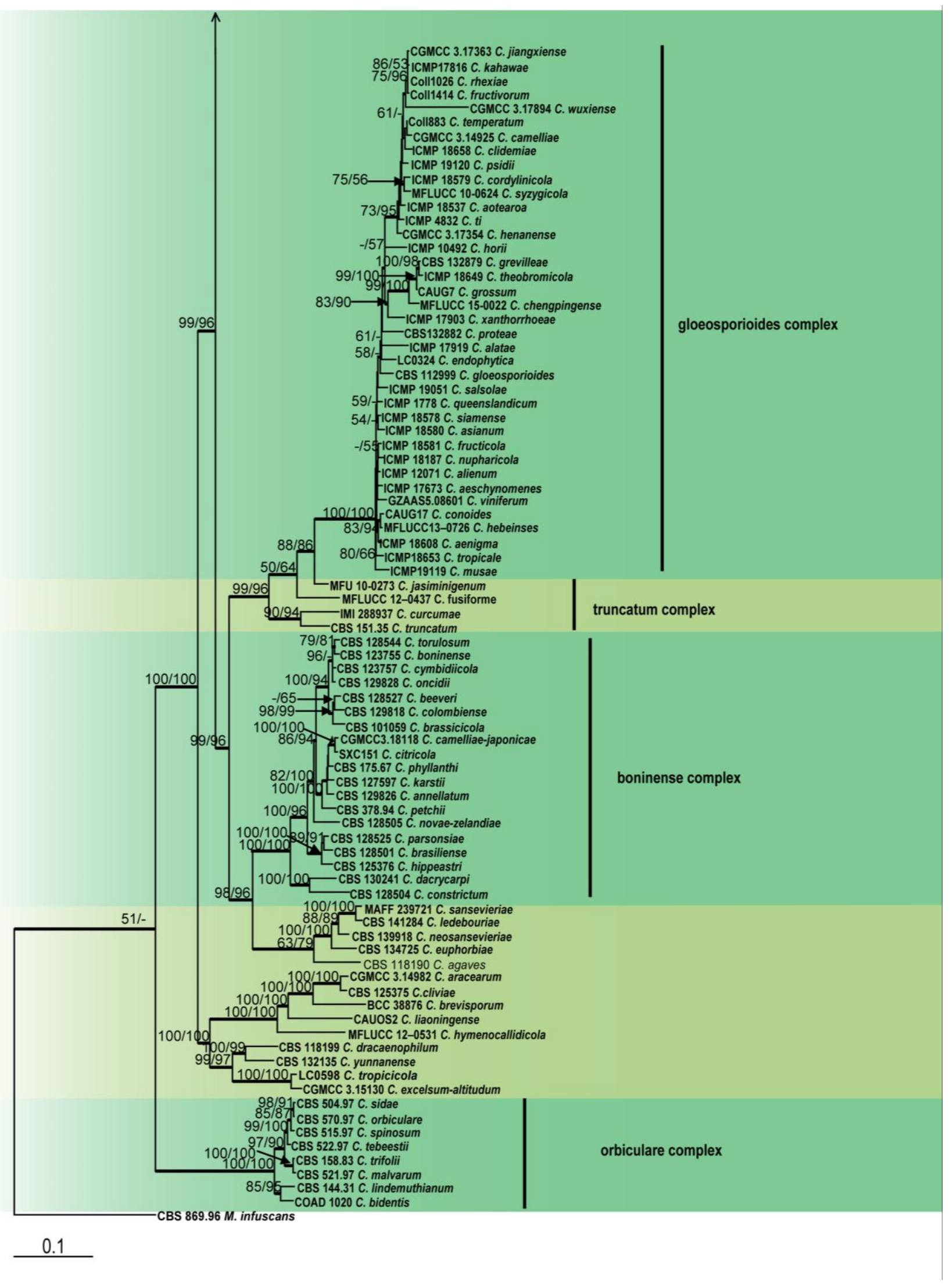

Fig. 1 (continued)

Species complexes 

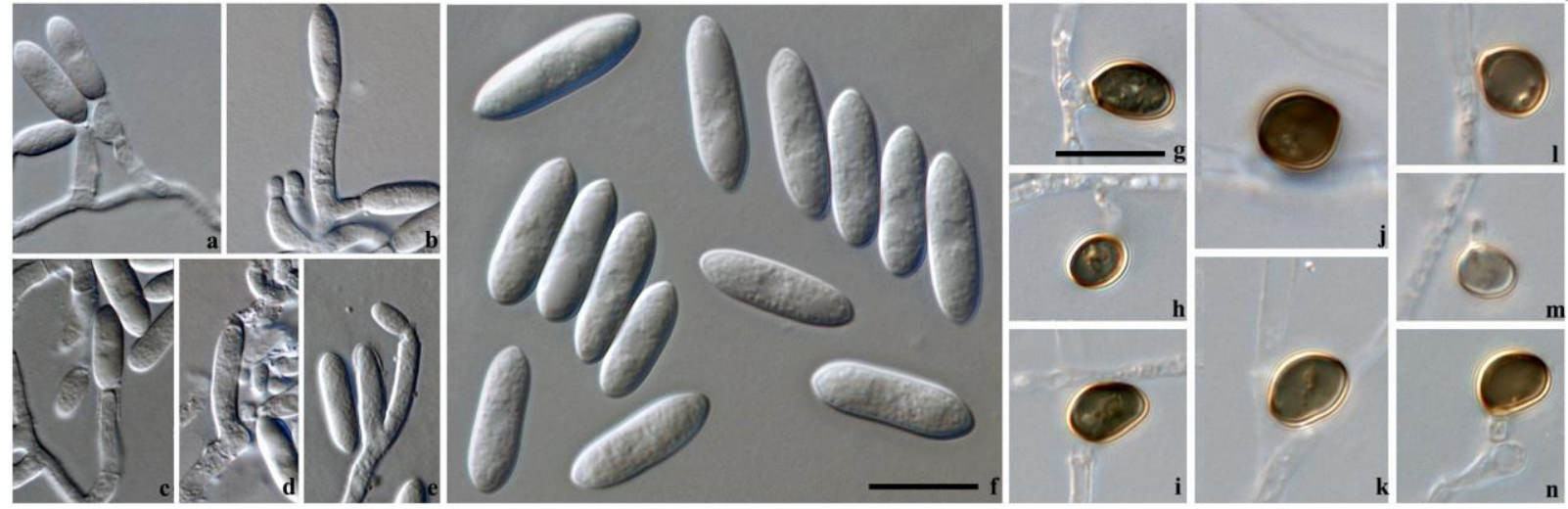

Fig. 2 Colletotrichum acutatum (from ex-type strain CBS 112996, on SNA) a-e. Conidiophores f. Conidia $\mathrm{g}-\mathrm{n}$. Appressoria. Scale bars: $\mathrm{f}, \mathrm{g}=10 \mu \mathrm{m}$; scale bar of $\mathrm{f}$ and $\mathrm{g}$ applies to a- $\mathrm{n}$ (Courtesy of U. Damm).

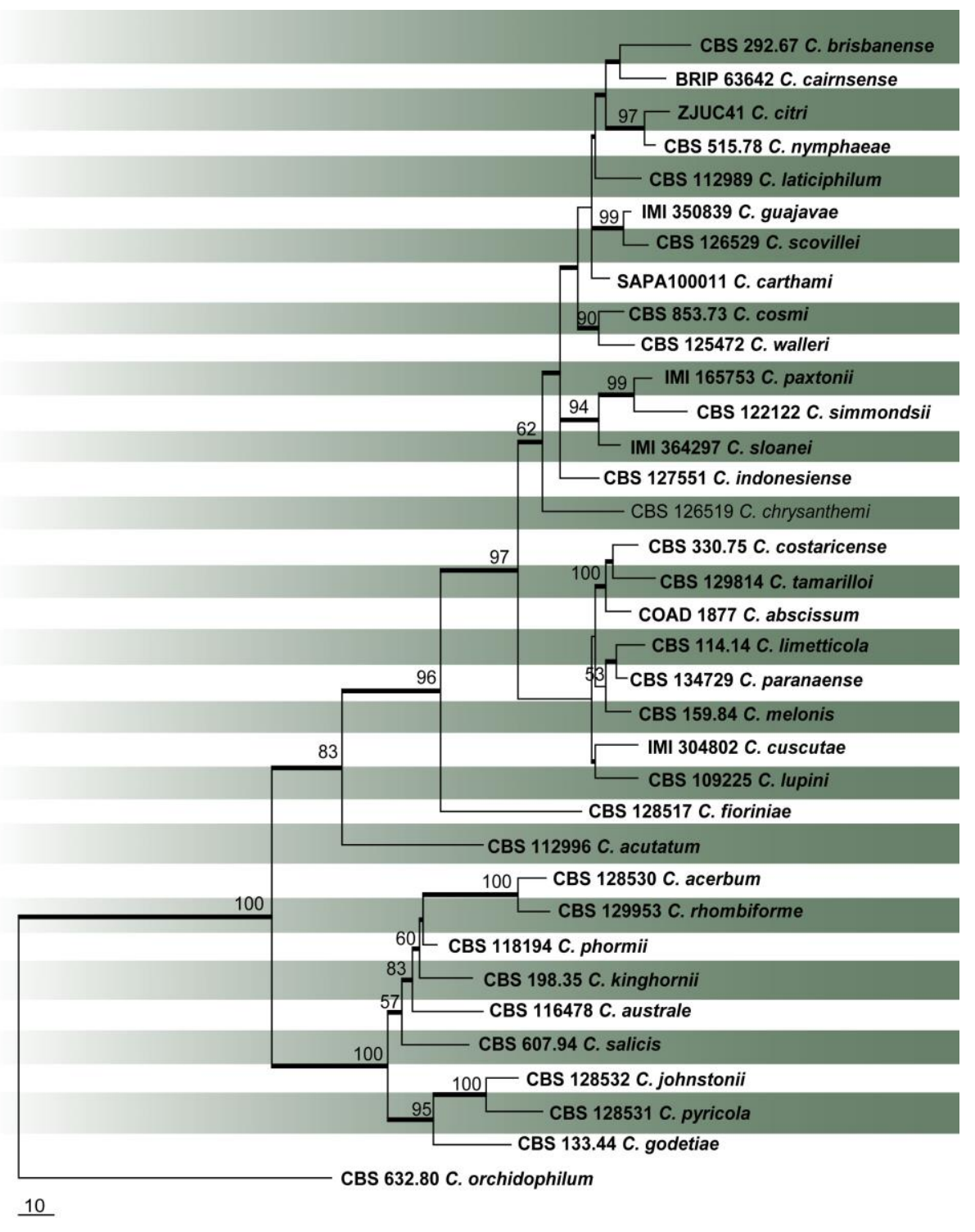

Fig. 3 One of the eight most parsimonious trees obtained from a heuristic search of combined ITS, GAPDH, CHS-1, HIS3, ACT and TUB2 sequence data of taxa from the acutatum species complex. Parsimony bootstrap support values above $50 \%$ are indicated at the nodes and branches with Bayesian posterior probabilities above 0.95 are given in bold. The ex-type strains are in bold. The tree is rooted with $C$. orchidophilum CBS 632.80. 


\section{Boninense species complex}

This species complex is defined as a collective of $C$. boninense and 18 closely related species with three main subclades containing 14, three and two species, respectively. Typical characters of species in this complex are the conidia that have a prominent basal scar as well as the conidiogenous cells with rather prominent periclinal thickening that sometimes extend to form a new conidiogenous locus (Damm et al. 2012a). Species of this complex are pathogens or endophytes (Damm et al. 2012a). A combined analysis of ITS, GAPDH, CHS-1, ACT, HIS3, TUB2 and CAL sequence of this species complex is given in Fig. 5. All species within this complex can be recognized with GAPDH alone (Damm et al. 2012a).
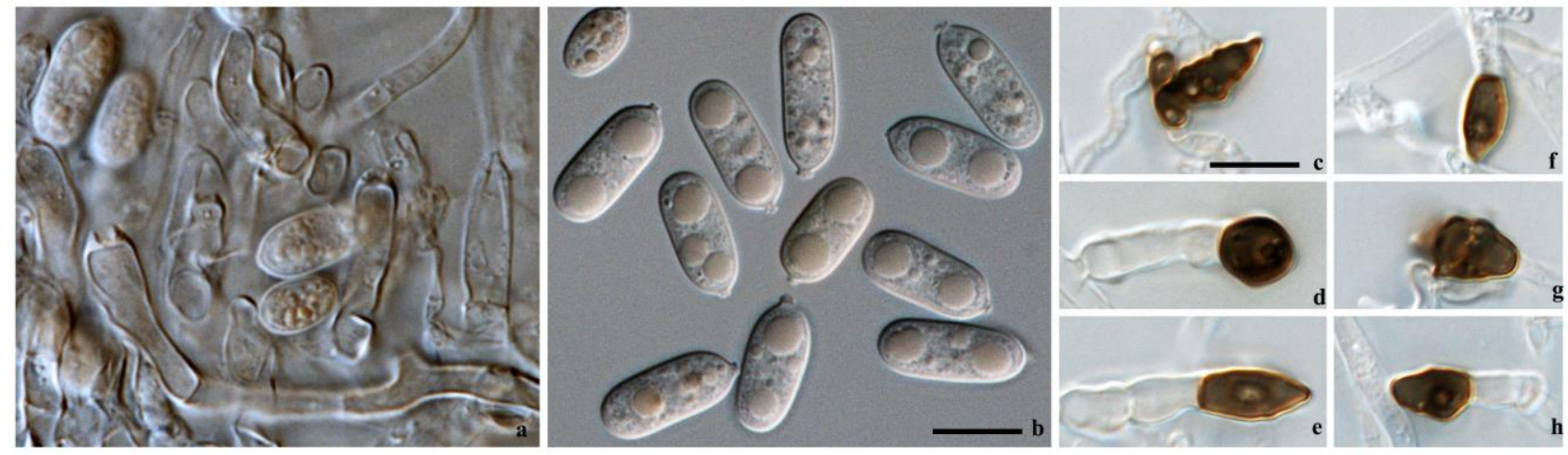

Fig. 4 Colletotrichum boninense (from ex-type strain CBS 123755, on SNA) a. Conidiophores b. Conidia $\mathrm{c}-\mathrm{h}$. Appressoria. Scale bars: $\mathrm{b}, \mathrm{c}=10 \mu \mathrm{m}$; scale bar of $\mathrm{b}$ and $\mathrm{c}$ applies to $\mathrm{a}-\mathrm{h}$ (Courtesy of U. Damm).

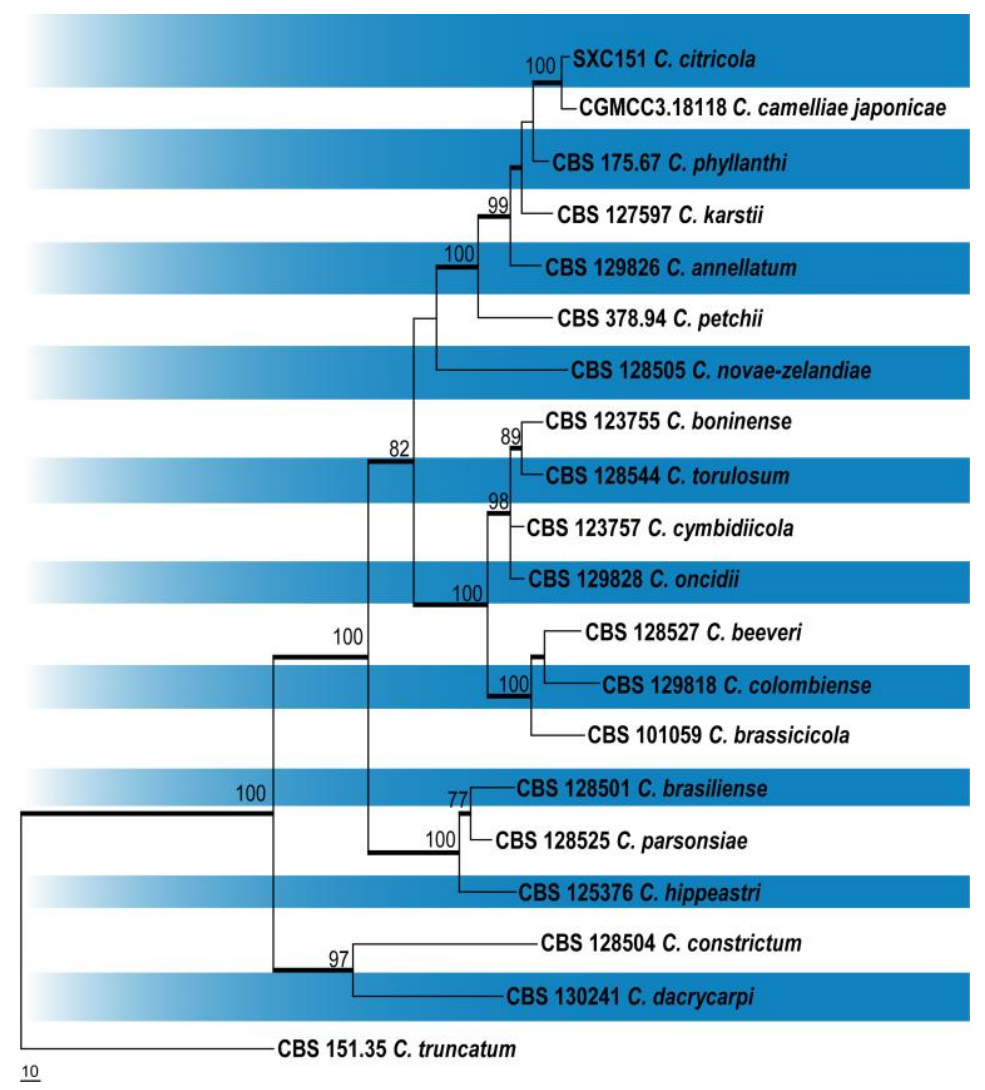

Fig. 5 The most parsimonious tree obtained from a heuristic search of combined ITS, GAPDH, CHS-1, ACT, HIS3, TUB2 and CAL sequence data of taxa from the boninense species complex. Parsimony bootstrap support values above $50 \%$ are indicated at the nodes and branches with Bayesian posterior probabilities above 0.95 are given in bold. The ex-type strains are in bold. The tree is rooted with C. truncatum CBS 151.35. 

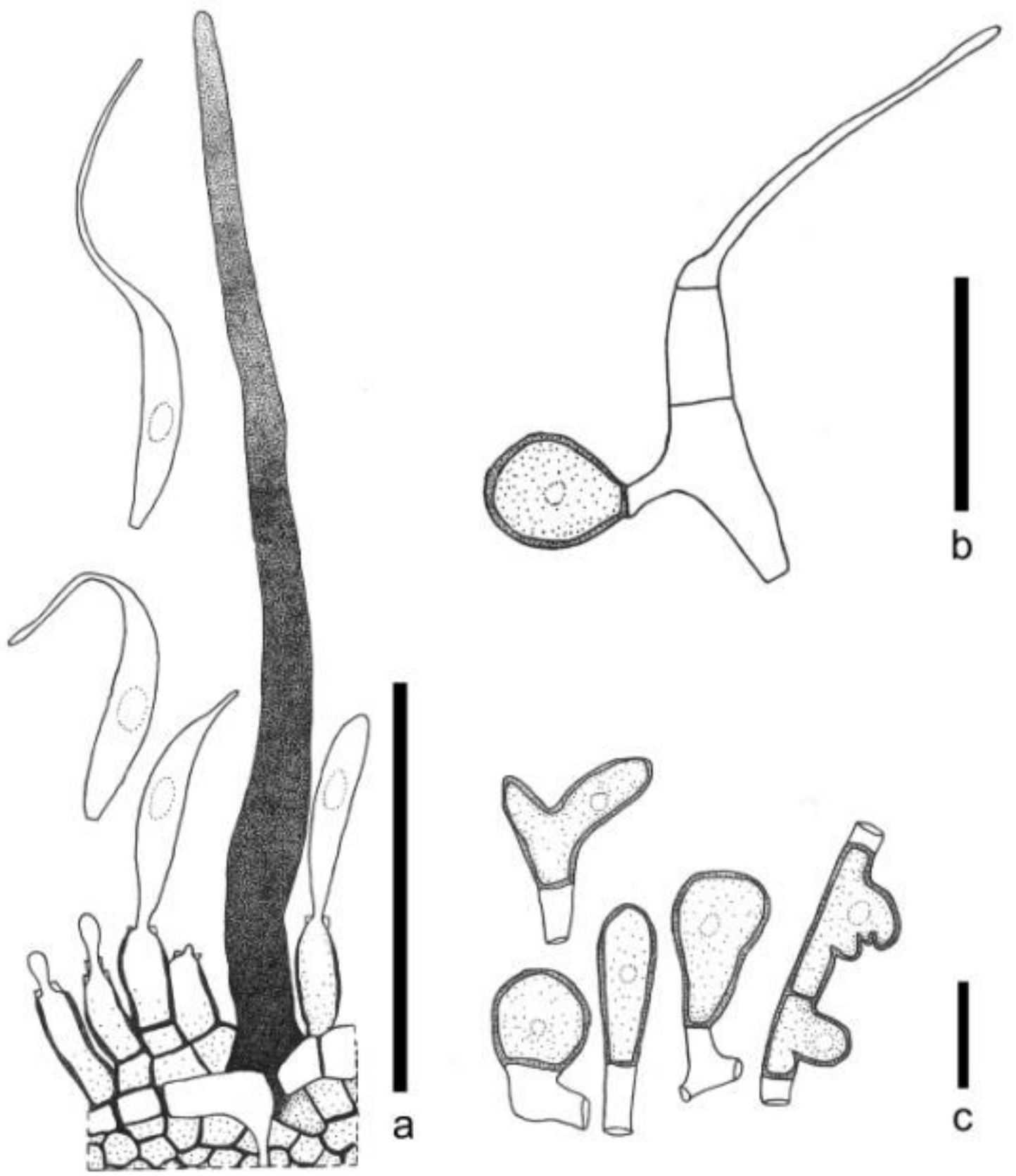

Fig. 6 Colletotrichum caudatum redrawn from NagRaj (1993). a. Seta with conidiogenous cells and developing conidia b. Germinating conidium c. Appressoria. Scale bars: a,b $=20 \mu \mathrm{m}, \mathrm{c}=5 \mu \mathrm{m}$. 


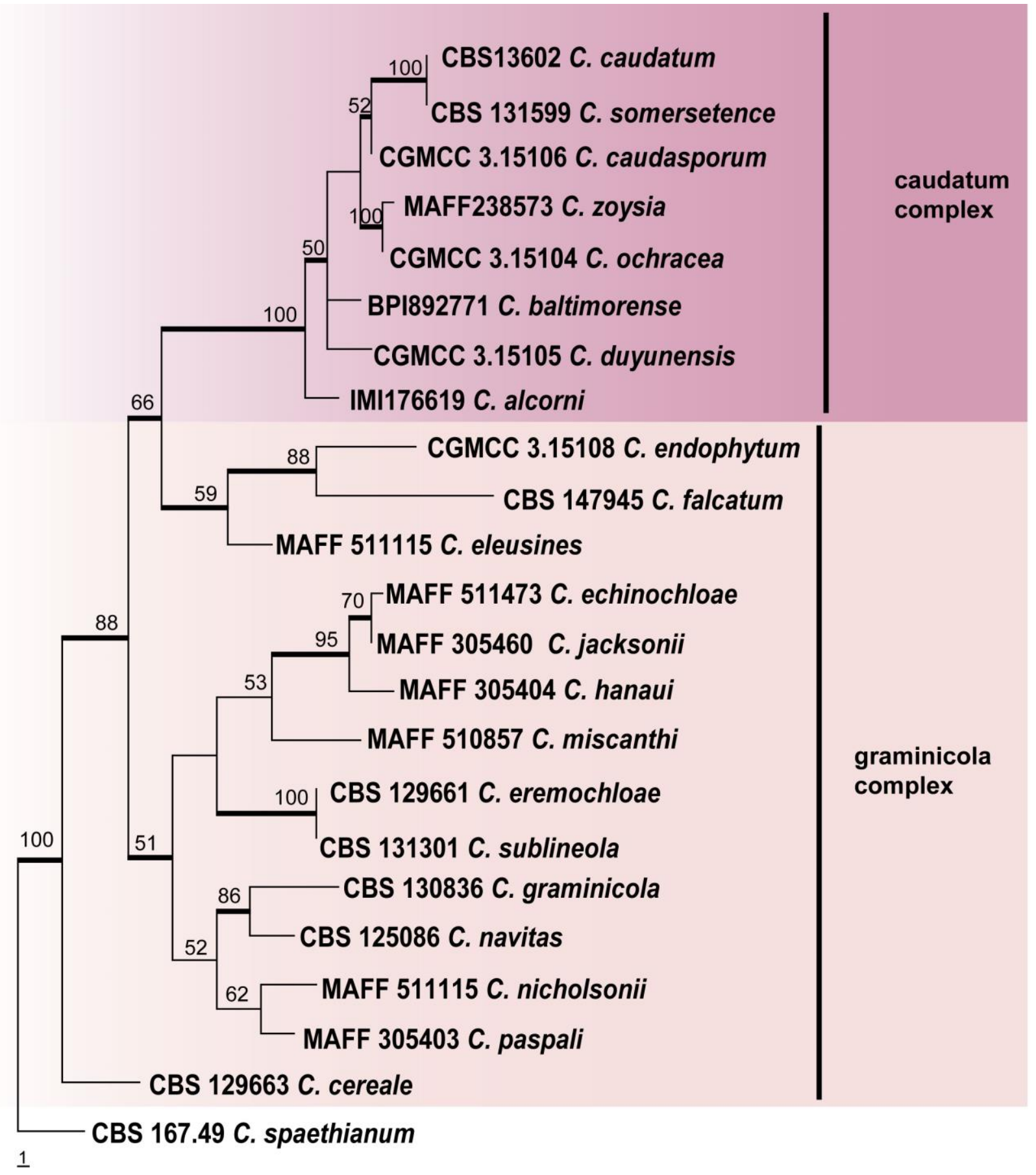

Fig. 7 The most parsimonious tree obtained from a heuristic search of ITS sequence data of taxa from the caudatum and graminicola species complex. Parsimony bootstrap support values above 50 $\%$ are indicated at the nodes and branches with Bayesian posterior probabilities above 0.95 are given in bold. The ex-type strains are in bold. The tree is rooted with C. spaethianum CBS 167.49.

\section{Caudatum species complex}

This species complex is defined as a collective of $C$. caudatum and seven closely related species. This complex can be distinguished by the presence of a filiform appendage at the apex of the conidium (Fig. 6) (Crouch 2014). A phylogenetic tree using ITS for the species of caudatum and graminicola species complexes has been constructed (Fig. 7). According to this phylogenetic tree, three species; $C$. caudasporum, $C$. duyuensis and $C$. ochracea which were previously identified to be in the graminicola species complex, clustered with the caudatum species complex. 
However, futher studies are needed to clarify whether to combine this complex with graminicola complex or to keep it as it is. Except for C. ochracea, the other two species agree with the morphology of the caudatum species complex. According to Fig. 7 caudatum complex appears to be a specific branch within the graminicola complex.

\section{Dematium species complex}

The dematium species complex includes $C$. dematium and ten closely related species. Species of this complex appear to be characteristic of temperate climates (Cannon et al. 2012). The type species of Colletotrichum, C. lineola, belongs in this species complex (Damm et al. 2009). There are two subclades within this complex. One clade comprises eight saprobic taxa, while the other comprises two pathogenic taxa and $C$. sedi being a saprobe. Typical are the conidia with an almost straight central part that bent abruptly to the apex and the truncate base, which gives them an almost angular shape (Fig. 8) (Damm et al. 2009). A combined gene analysis of ITS, GAPDH, CHS-1, ACT and TUB2 sequences of this species complex is shown in Fig. 9.
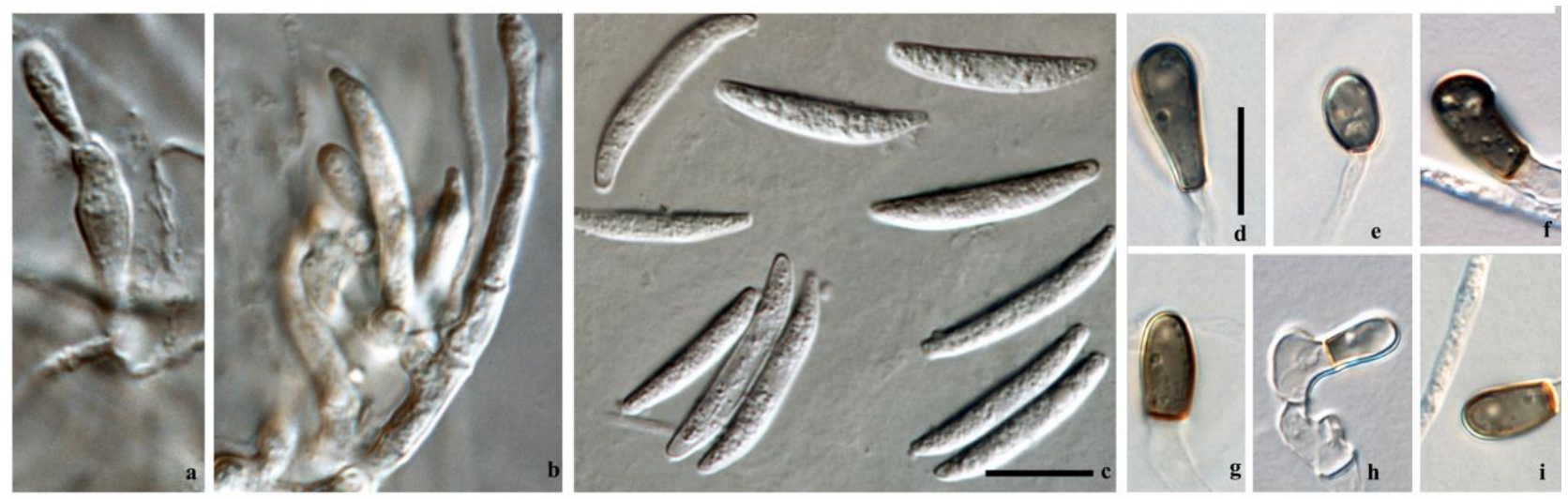

Fig. 8 Colletotrichum dematium (from ex-type strain CBS 125.25, on SNA) a-b. Conidiophores c. Conidia d-i. Appressoria. Scale bars: $\mathrm{c}, \mathrm{d}=10 \mu \mathrm{m}$; scale bar of $\mathrm{c}$ and $\mathrm{d}$ applies to $\mathrm{a}-\mathrm{i}$ (Courtesy of U. Damm).

\section{Destructivum species complex}

The destructivum species complex is a collective of $C$. destructivum and 14 closely related species that are mainly plant pathogens (Damm et al. 2014). The lifestyle of all species in this complex that had been examined in vivo is hemibiotrophic (Damm et al. 2014). O'Connell et al. (2012) showed that the destructivum species complex is monophyletic and distinct from other Colletotrichum species complexes. Species of this complex are characterized by conidia that are slightly curved due to their unilaterally tapering ends and by small inconspicuous acervuli with rather effuse growth (Fig. 10) (Damm et al. 2014). A combined analysis of ITS, GAPDH, CHS-1, HIS3, ACT and TUB2 sequences is given in Fig. 11. According to Damm et al. (2014) all species can be identified by a combination of TUB2 and GAPDH sequences.

\section{Gigasporum species complex}

The gigasporum species complex consists of $C$. gigasporum and five closely related species and is characterised by the formation of large $(>20 \mu \mathrm{m})$ conidia (Fig. 12) (Liu et al. 2014). Species of this complex can be either pathogens or endophytes. A combined analyses of ACT, CHS-1, GAPDH, ITS and TUB2 sequences of this complex is given in Fig. 13. All species within this complex can be identified by any of these five genes (Liu et al. 2014). 


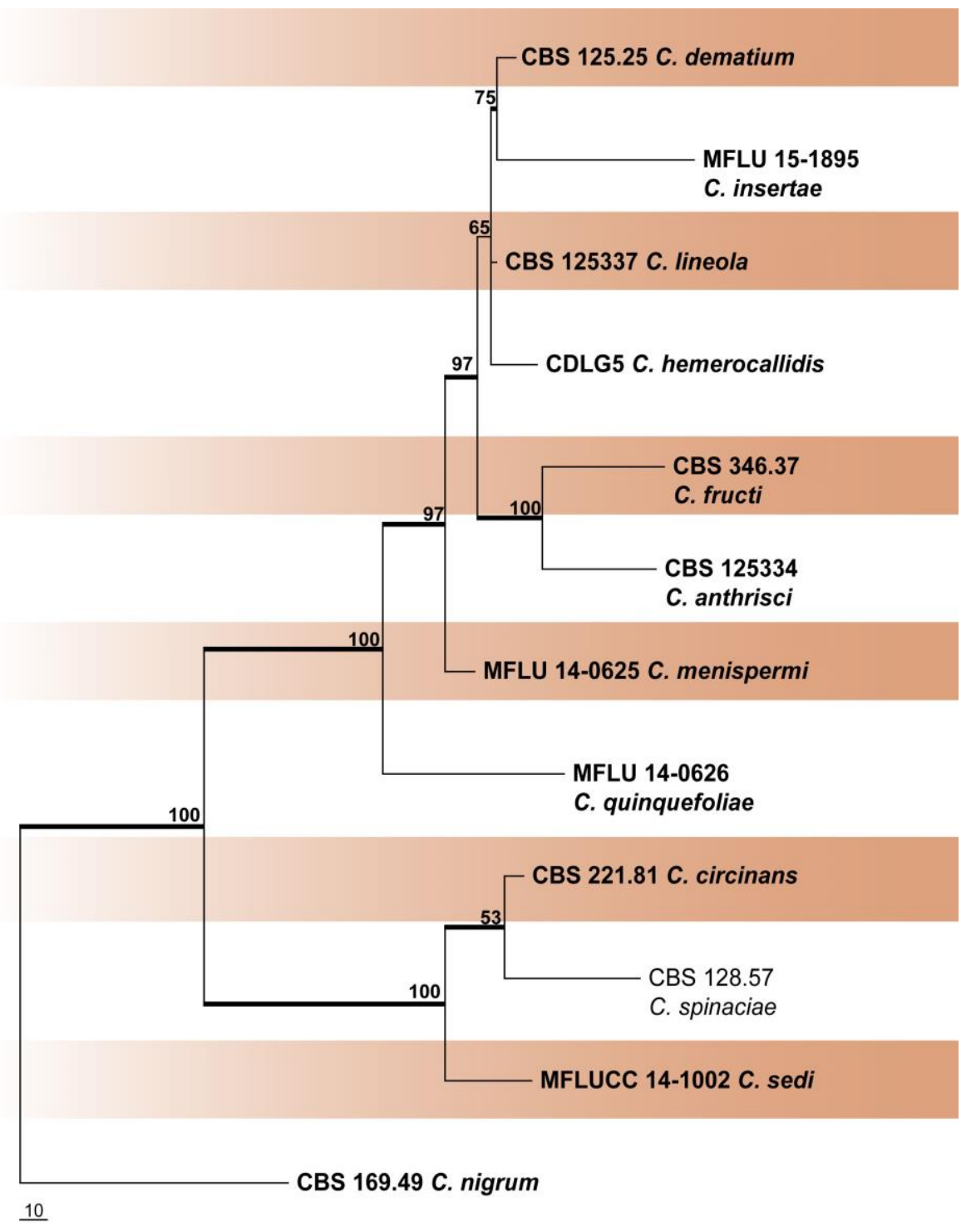

Fig. 9 One of the two most parsimonious trees obtained from a heuristic search of combined ITS, GAPDH, CHS-1, ACT and TUB2 sequence data of taxa from the dematium species complex. Parsimony bootstrap support values above $50 \%$ are indicated at the nodes and branches with Bayesian posterior probabilities above 0.95 are given in bold. The ex-type strains are in bold. The tree is rooted with $C$. nigrum CBS 169.49 .
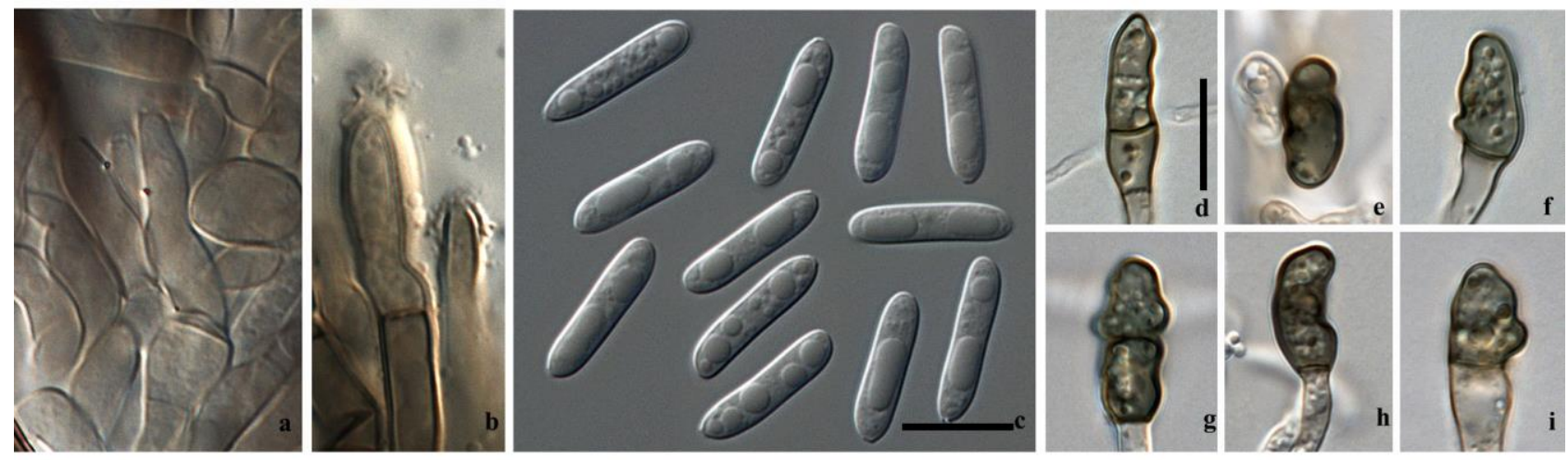

Fig. 10 Colletotrichum destructivum (from ex-type strain CBS 136228, on SNA) a-b. Conidiophores c. Conidia d-i. Appressoria. Scale bars: c, $\mathrm{d}=10 \mu \mathrm{m}$; scale bar of $\mathrm{c}$ and $\mathrm{d}$ applies to a-i (Courtesy of U. Damm). 
CBS 102189 C. antirrhinicola

CBS 133701 C. fuscum

90

CBS 109849 C. bryoniicola

93

CBS 501.97 C. vignae

97

IMI 349061 C. higginsianum

92

C08087 C. panacicola

CBS 130243 C. utrechtense

CPC 18945 C. tabacum

CBS 136228 C. destructivum

100

CBS 136228 C. destructivum

88

CBS 298.94 C. ocimi

C CBS 136232 C. americae-borealis

100

CBS 172.51 C. lini

CBS 127604 C. lentis

CBS 724.97 C. pisicola

CBS 132693 C. tanaceti

CBS 369.75 C. coccodes

10

Fig. 11 One of the two most parsimonious trees obtained from a heuristic search of combined ITS, GAPDH, CHS-1, HIS3, ACT and TUB2 sequence data of taxa from the destructivum species complex. Parsimony bootstrap support values above $50 \%$ are indicated at the nodes and branches with Bayesian posterior probabilities above 0.95 are given in bold. The ex-type strains are in bold. The tree is rooted with $C$. coccodes CBS 369.75 . 

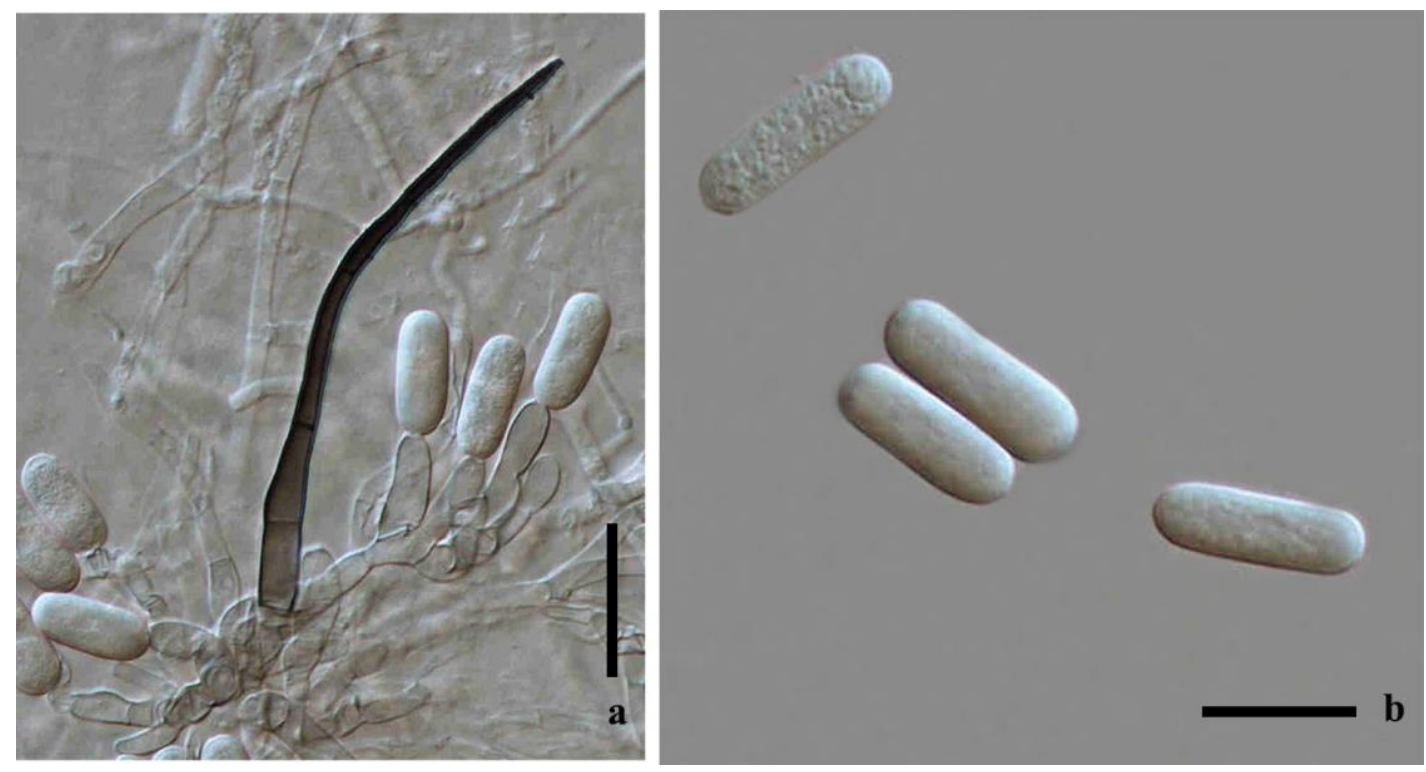

Fig. 12 Colletotrichum gigasporum (from strain CBS 181.52, on SNA) a. Conidiophores and a seta b. Conidia. Scale bars: $\mathrm{a}-\mathrm{b}=10 \mu \mathrm{m}$ (Courtesy of F. Liu).

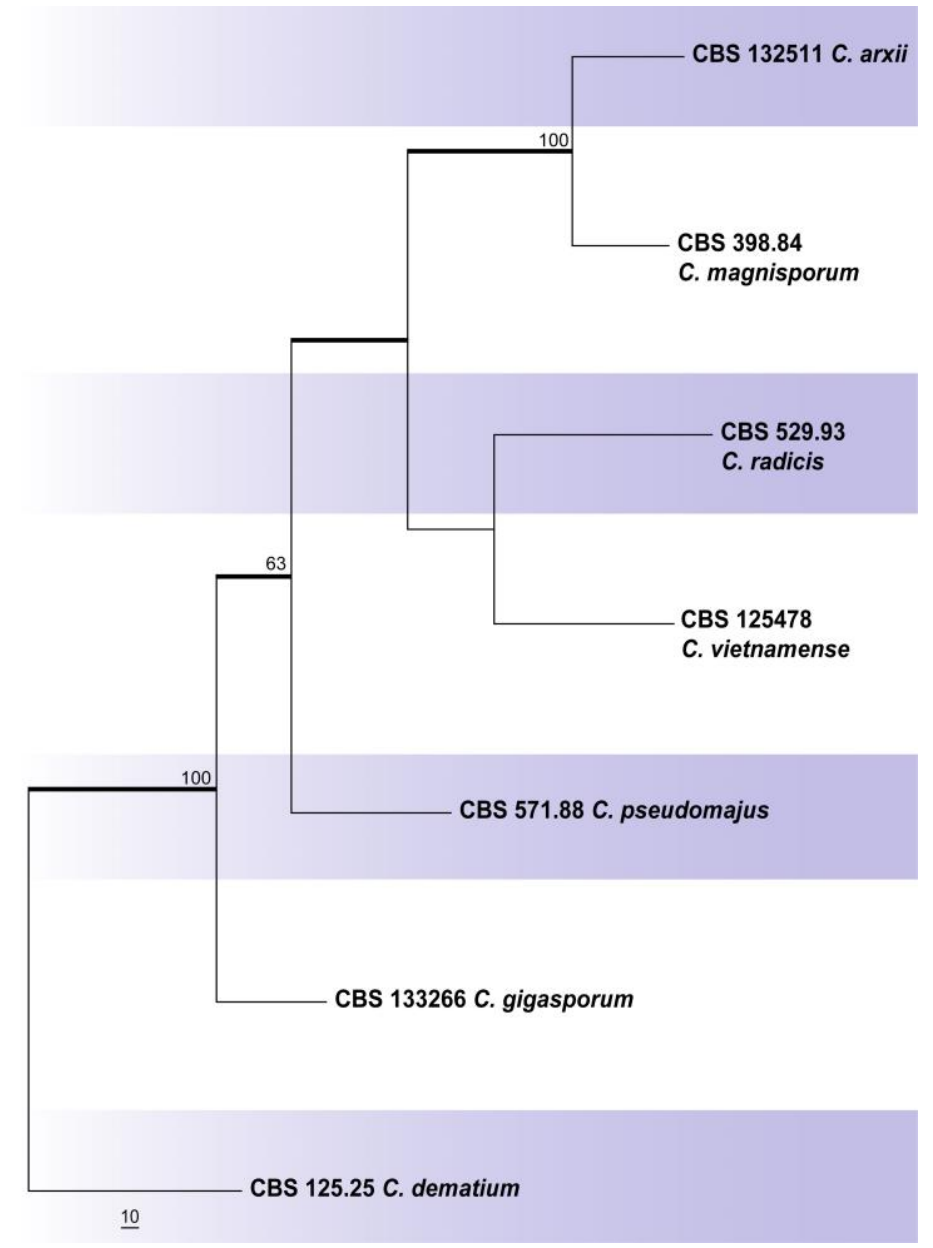

Fig. 13 One of the two most parsimonious trees obtained from a heuristic search of combined ACT, CHS-1, GAPDH, ITS and TUB2 sequence data of taxa from the gigasporum species complex. Parsimony bootstrap support values above $50 \%$ are indicated at the nodes and branches with Bayesian posterior probabilities above 0.95 are given in bold. The ex-type strains are in bold. The tree is rooted with $C$. dematium CBS 125.25. 


\section{Gloeosporioides species complex}

The gloeosporioides species complex is a collective of $C$. gloeosporioides and 37 closely related species (Fig. 14). This species complex mainly consists of plant pathogens (Weir et al. 2012), but some species were isolated as endophytes (Liu et al. 2015a). Conidia of this species complex are cylindrical with rounded ends tapering slightly towards the base (Fig. 13) (Weir et al. 2012). Based on the multigene phylogeny, Weir et al. (2012) recognized two subclades within the species complex, namely kahawae and musae (Fig. 15). A combination of ApMat and GS sequences can be used to distinguish the species within this complex (Liu et al. 2015a). A phylogenetic tree constructed using ApMat gene alone for this complex is given in Fig. 16.
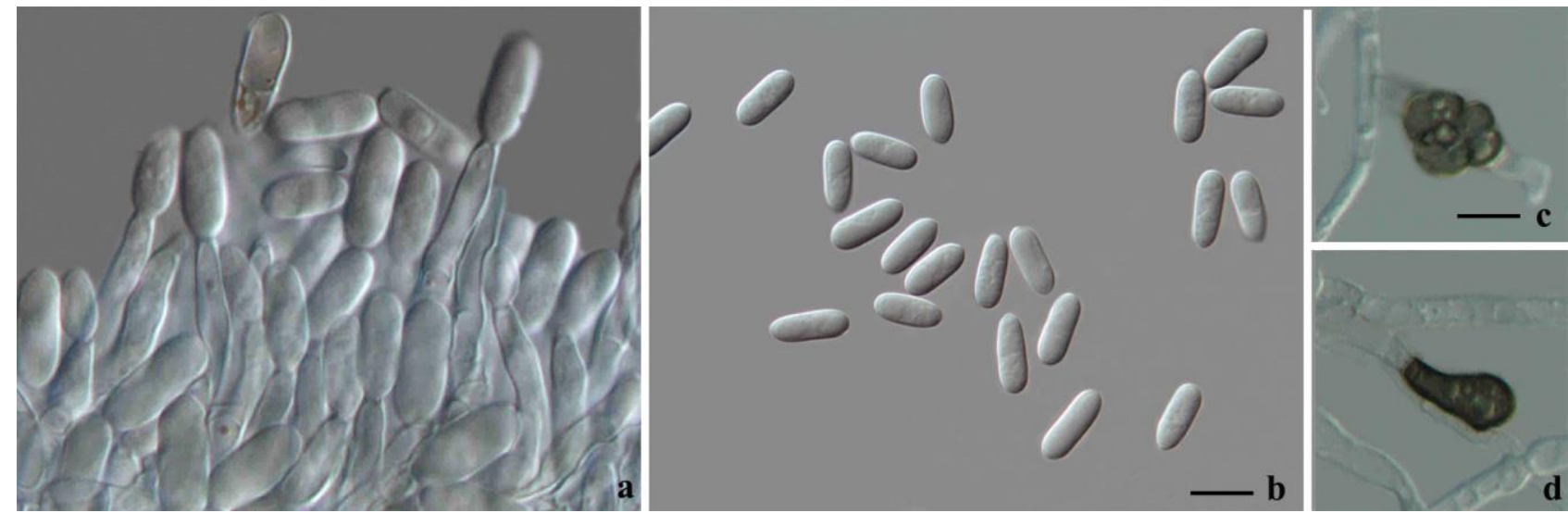

Fig. 14 Colletotrichum gloeosporioides (from strain CGMCC 3.17360, on SNA). a. Conidiogenous cells b. Conidia $\mathrm{c}-\mathrm{d}$. Appressoria. Scale bars: b, $\mathrm{c}=10 \mu \mathrm{m}$; scale bar of b and $\mathrm{c}$ applies to $\mathrm{a}-\mathrm{d}$ (Courtesy of F. Liu).

\section{Graminicola species complex}

The graminicola species complex includes $C$. graminicola and 14 closely related species that are only associated with certain grasses (Poaceae) and form a monophyletic clade (Cannon et al. 2012). Species are characterized by widely falcate conidia (Fig. 17) (Crouch et al. 2009a). Several species of this complex are important pathogens. Results of a combined analysis of ITS, GAPDH, CHS-1, ACT and TUB2 sequence data are presented in Fig. 18.

\section{Orbiculare species complex}

The orbiculare species complex includes $C$. orbiculare and seven closely related species that are plant pathogens and are restricted to specific herbaceous host genera or species (Damm et al. 2013). The lifestyle of these species has been characterized as hemibiotrophic (Goodwin 2001, Damm et al. 2013). Members of the orbiculare species complex form conidia that are straight and relatively broad and short. Appressoria of these species are small and simple in outline (Fig. 19) (Damm et al. 2013). Results of a combined analysis of ITS, GAPDH, CHS-1, ACT, HIS3, TUB2 and GS sequence data are presented in Fig. 20. All species in this complex can be identified based on GS sequences alone (Damm et al. 2013).

\section{Spaethianum species complex}

The spaethianum species complex includes $C$. spaethianum and nine closely related species. Species in this species complex form complex appressoria (Fig. 21) (Damm et al. 2009). A multigene analysis comprised of ITS, GAPDH, CHS-1, ACT, HIS3 and TUB2 is given in Fig. 22. 


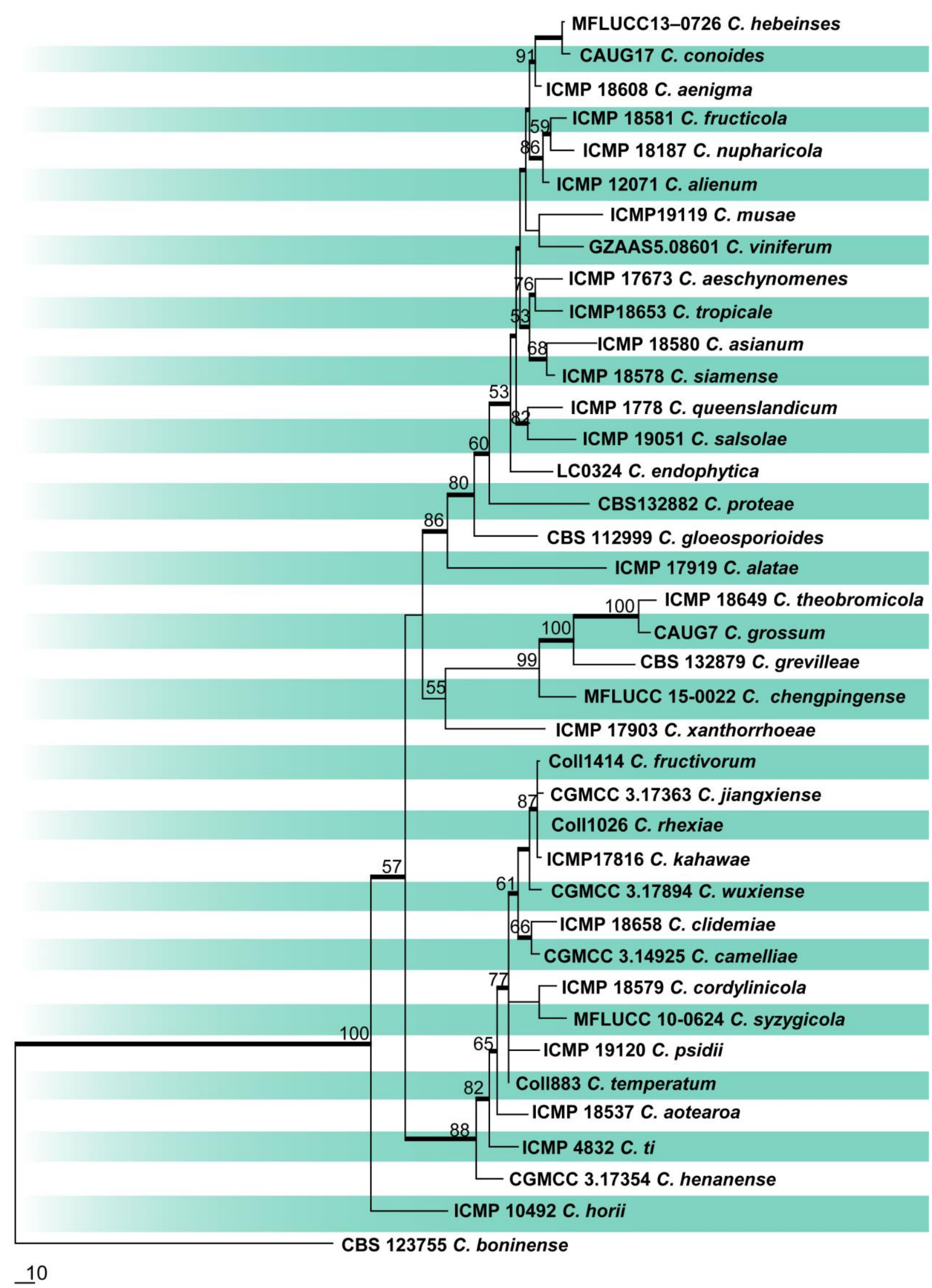

Fig. 15 One of the ten most parsimonious trees obtained from a heuristic search of combined ACT, TUB2, CAL, CHS-1, GAPDH and ITS sequence data for taxa from the gloeosporioides species complex. Parsimony bootstrap support values above $50 \%$ are indicated at the nodes and branches with Bayesian posterior probabilities above 0.90 are given in bold. The ex-type strains are in bold. The tree is rooted with $C$. boninense CBS 123755. 


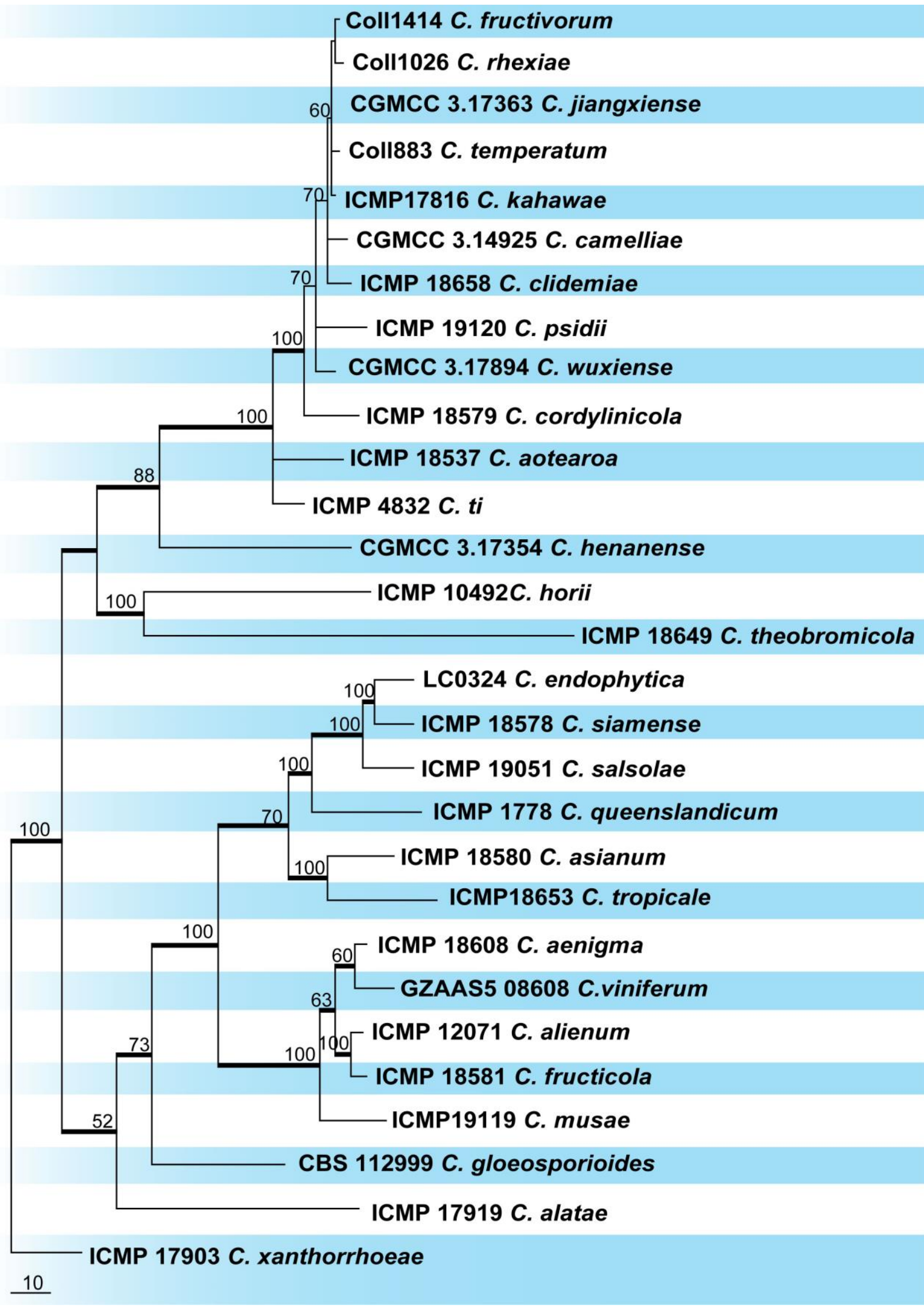

Fig. 16 One of the two most parsimonious trees obtained from a heuristic search of Apmat sequence data of taxa from the gloeosporioides species complex. Parsimony bootstrap support values above $50 \%$ are indicated at the nodes and branches with Bayesian posterior probabilities above 0.80 are given in bold. The ex-type strains are in bold. The tree is rooted with $C$. xanthorrhoeae ICMP 17903. 


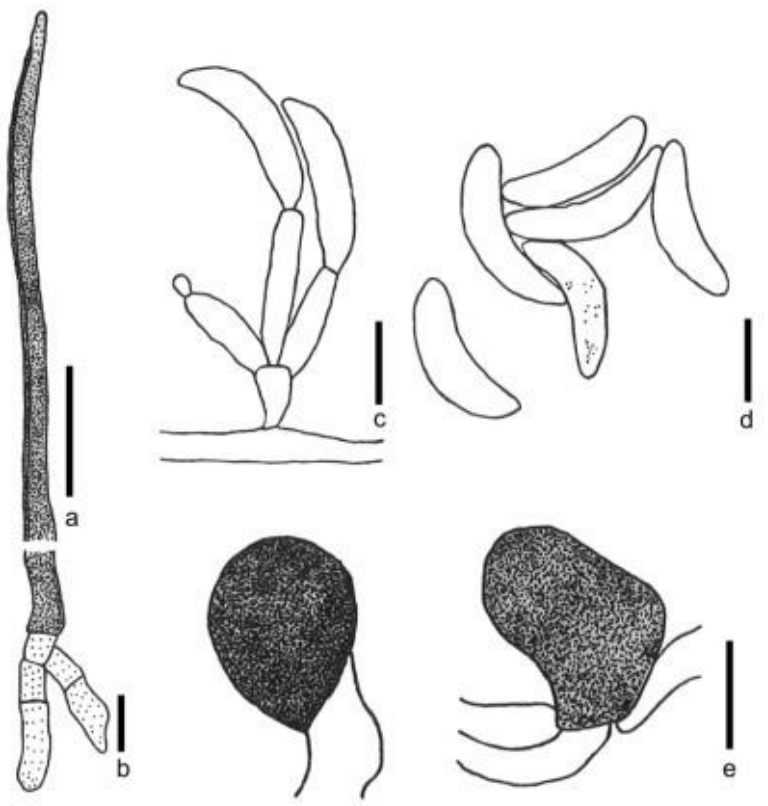

Fig. 17 Colletotrichum graminicola redrawn from Politis (1975) and Panaccione et al. (1989). a. Tip of a seta $\mathrm{b}$. Base of a seta c. Conidiogenous cells d. Conidia e. Appressoria. Scale bars: $\mathrm{a}, \mathrm{b}=$ $20 \mu \mathrm{m}, \mathrm{c}=5 \mu \mathrm{m}$.

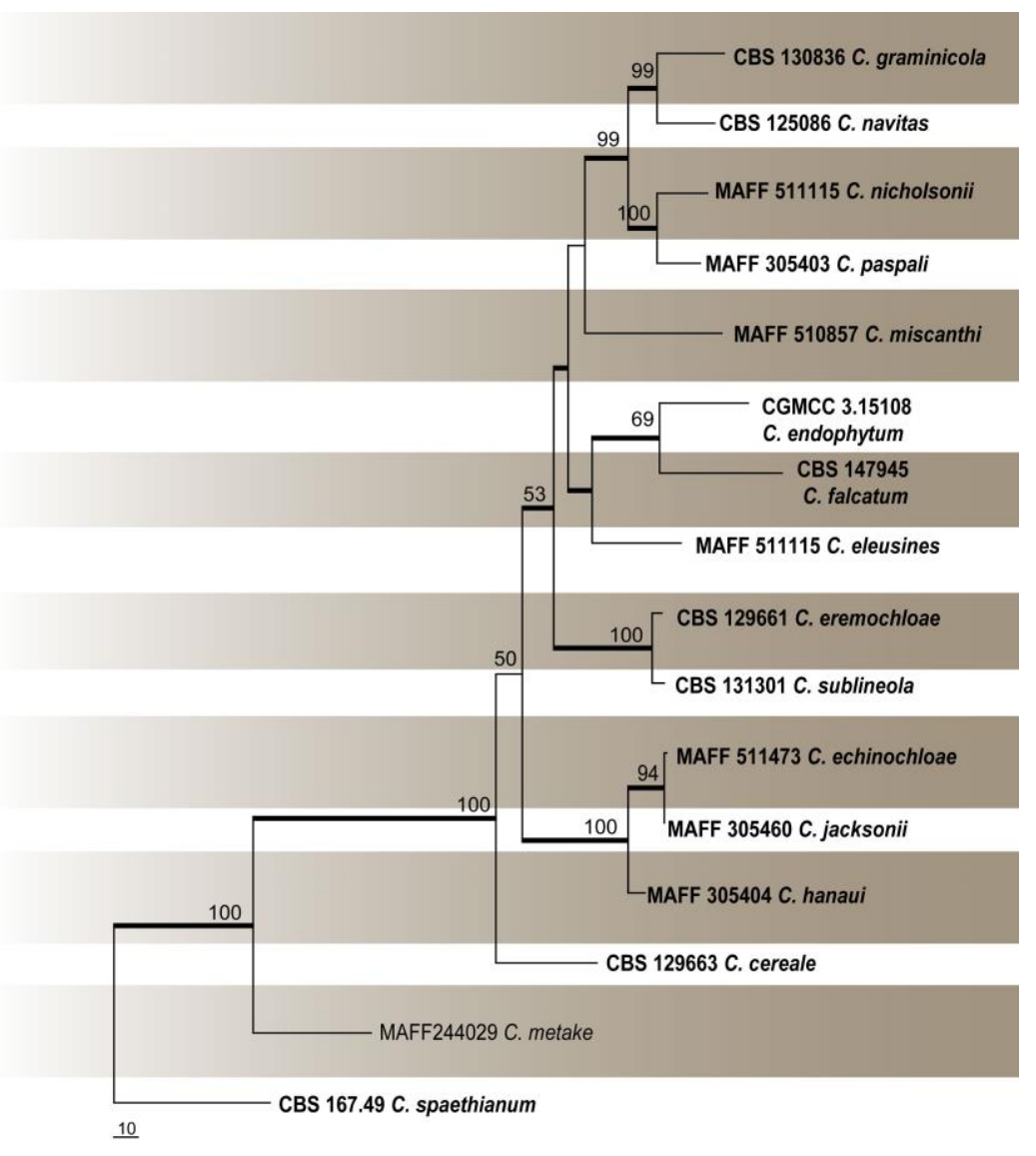

Fig. 18 One of the two most parsimonious trees obtained from a heuristic search of combined ITS, GAPDH, CHS-1, ACT and TUB2 sequence data of taxa from the graminicola species complex. Parsimony bootstrap support values above $50 \%$ are indicated at the nodes and branches with Bayesian posterior probabilities above 0.95 are given in bold. The ex-type strains are in bold. The tree is rooted with $C$. spaethianum CBS 167.49. 

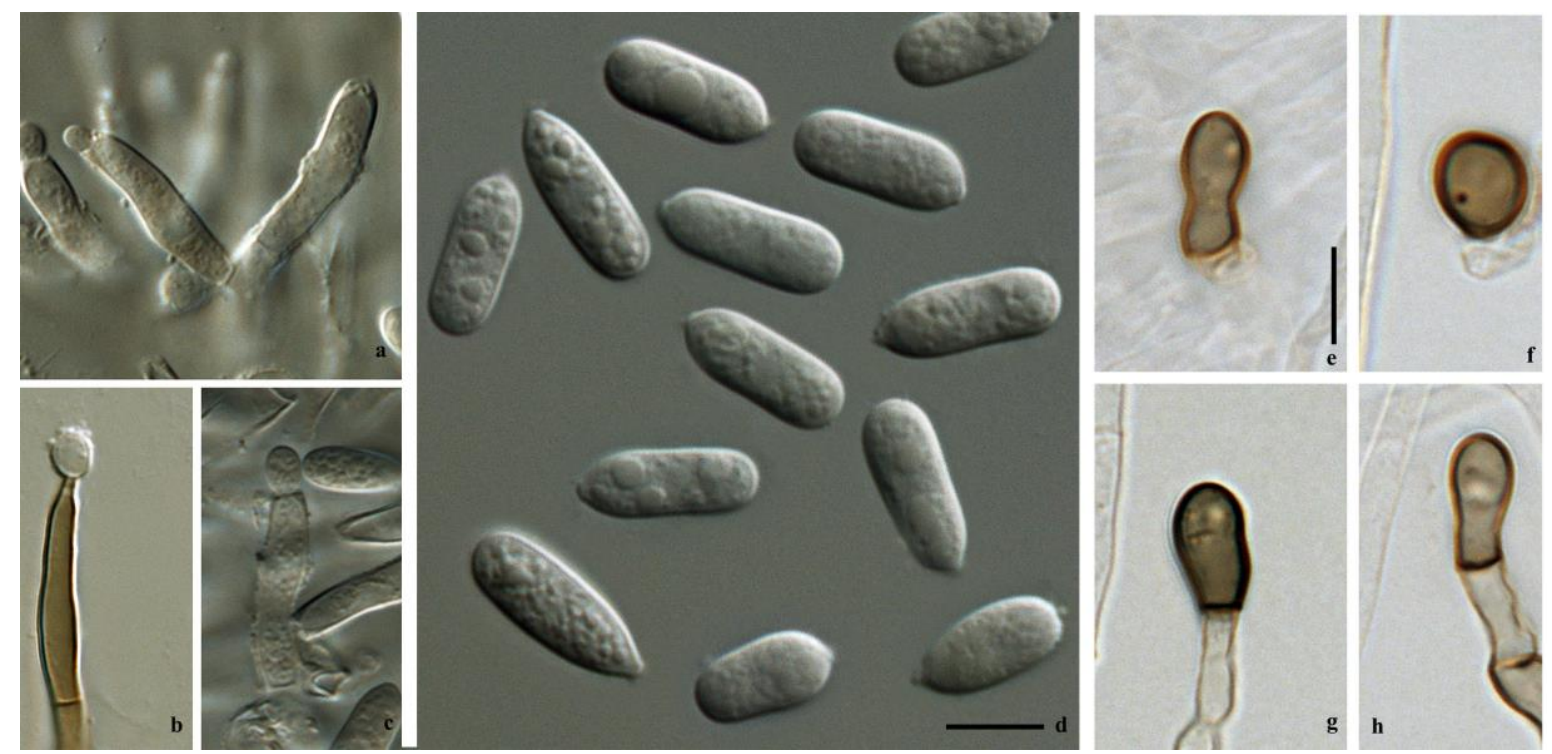

Fig. 19 Colletotrichum orbiculare (a, d-h from ex-type strain CBS 570.97, b-c from strain CBS 133196, on SNA) a-c. Conidiophores d. Conidia e-h. Appressoria. Scale bars: d, e = 10 $\mu \mathrm{m}$; scale bar of $d$ and e applies to $a-h$ (Courtesy of U. Damm).

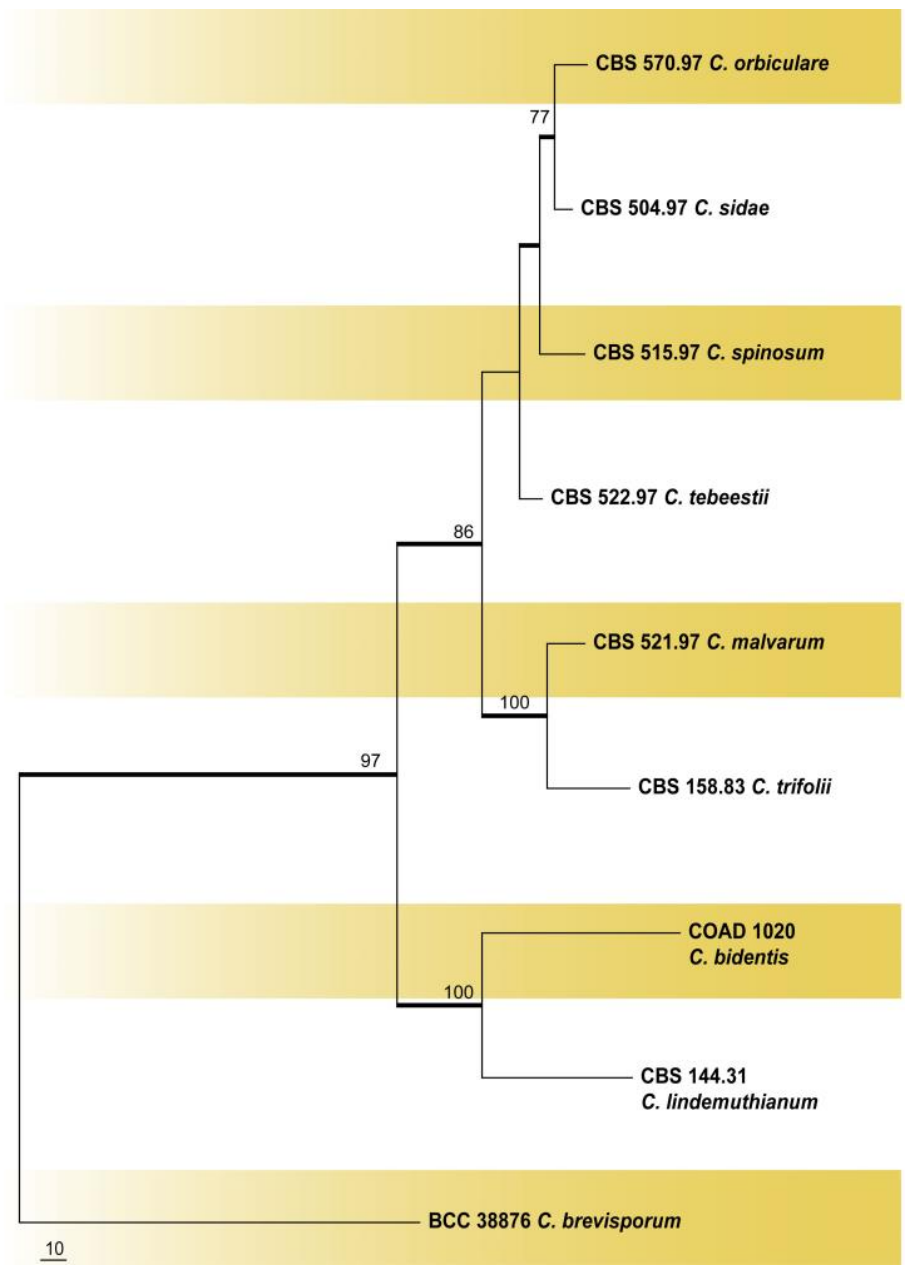

Fig. 20 One of the two most parsimonious trees obtained from a heuristic search of combined ITS, GAPDH, CHS-1, ACT, HIS3, TUB2 and GS sequence data of taxa from the orbiculare species complex. Parsimony bootstrap support values above $50 \%$ are indicated at the nodes and branches with Bayesian posterior probabilities above 0.90 are given in bold. The ex-type strains are in bold. The tree is rooted with C. brevisporum BCC 38876. 

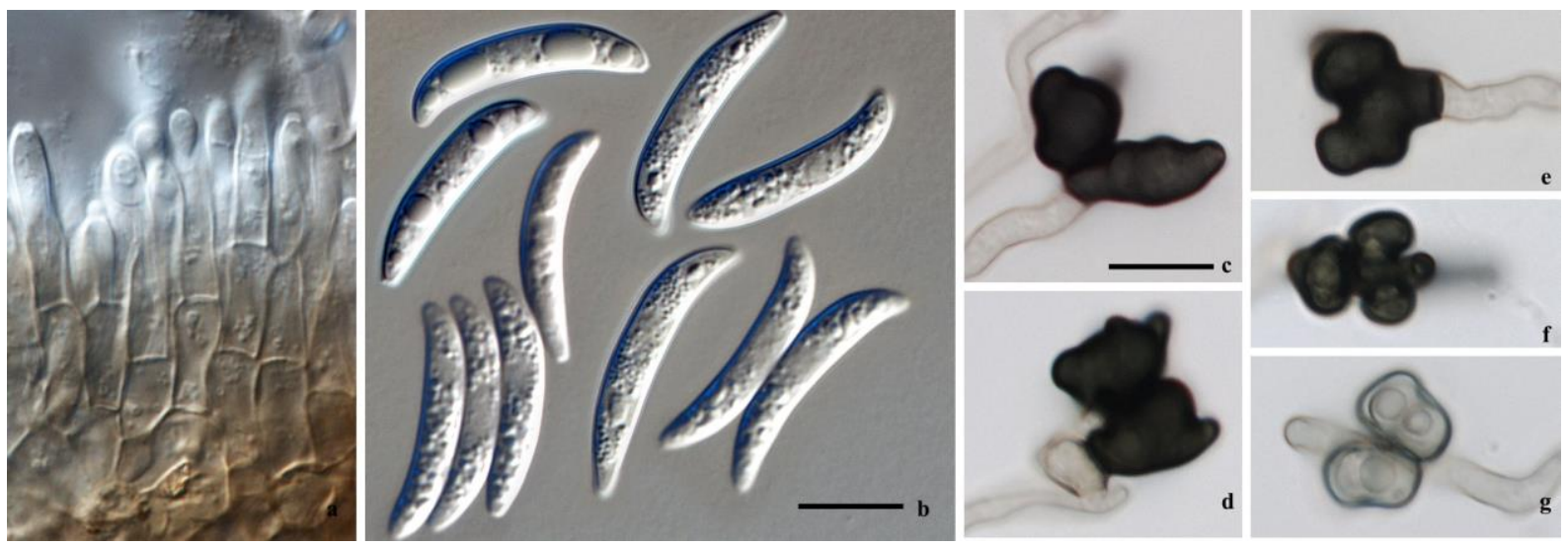

Fig. 21 Colletotrichum spaethianum (a, c-g from CBS 1100063, b from ex-type strain CBS 167. 49, on SNA) a. Conidiophores b. Conidia c-g. Appressoria. Scale bars: a-c $=10 \mu \mathrm{m}$ (Courtesy of U. Damm).

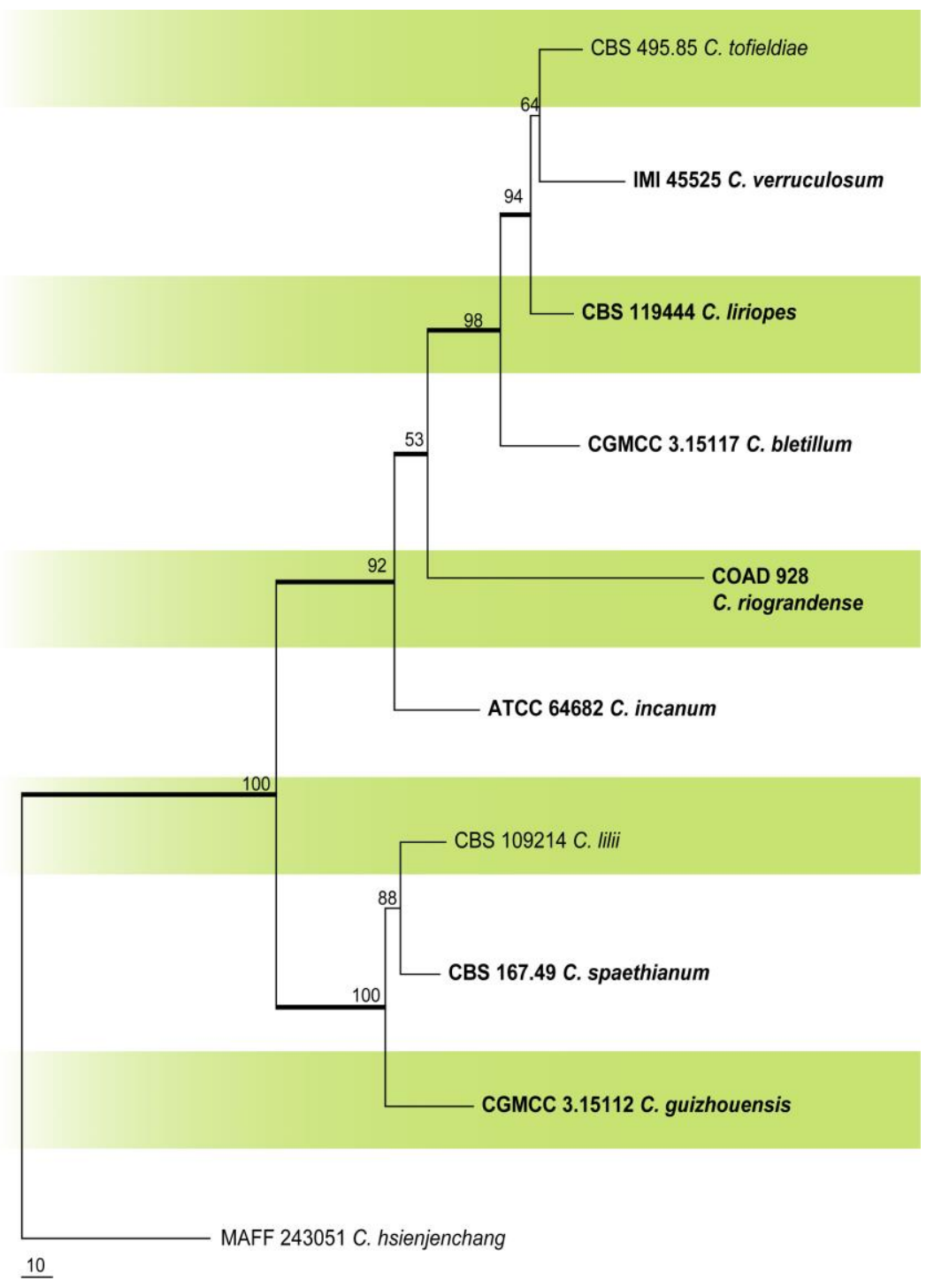

Fig. 22 The most parsimonious tree obtained from a heuristic search of combined ITS, GAPDH, CHS-1, ACT, HIS3 and TUB2 sequence data of taxa from the spaethianum species complex. Parsimony bootstrap support values above $50 \%$ are indicated at the nodes and branches with Bayesian posterior probabilities above 0.95 are given in bold. The ex-type strains are in bold. The tree is rooted with $C$. hsienjenchang MAFF 243051. 


\section{Truncatum species complex}

The truncatum species complex includes $C$. truncatum and three closely related species that are pathogens (Damm et al. 2009, Wikee et al. 2011). This complex can be distinguished by their curved conidia with truncated base and acute, more strongly curved apex. Presence of appressoria in groups and dense clusters is also characteristic (Fig. 23) (Damm et al. 2009). A combined analysis of ITS, GAPDH, CHS-1, ACT, HIS3 and TUB2 sequences is given in Fig. 24.
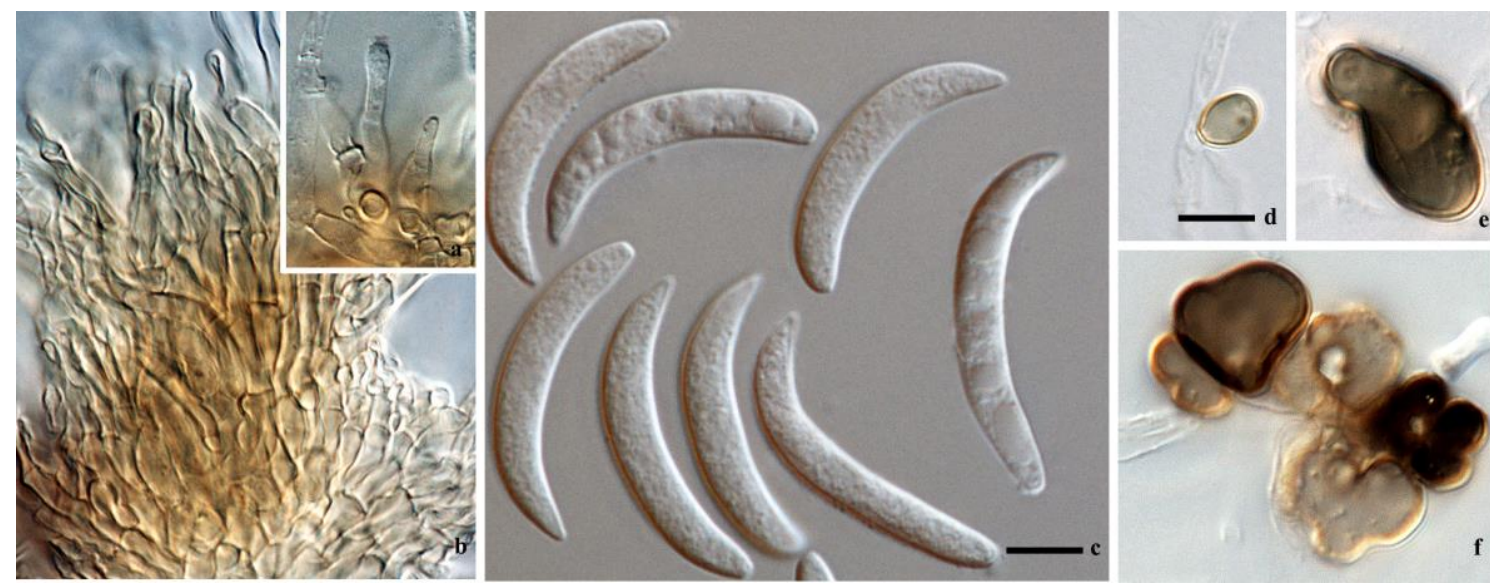

Fig. 23 Colletotrichum truncatum (a-c from ex-type strain CBS 151. 35, d-f from strain CBS 120709, on SNA). a. Tip of the seta b. Base of the seta c. Conidiophores d. Conidia e. Appressoria. Scale bars: a,e $=10 \mu \mathrm{m}$ (Courtesy of U. Damm).

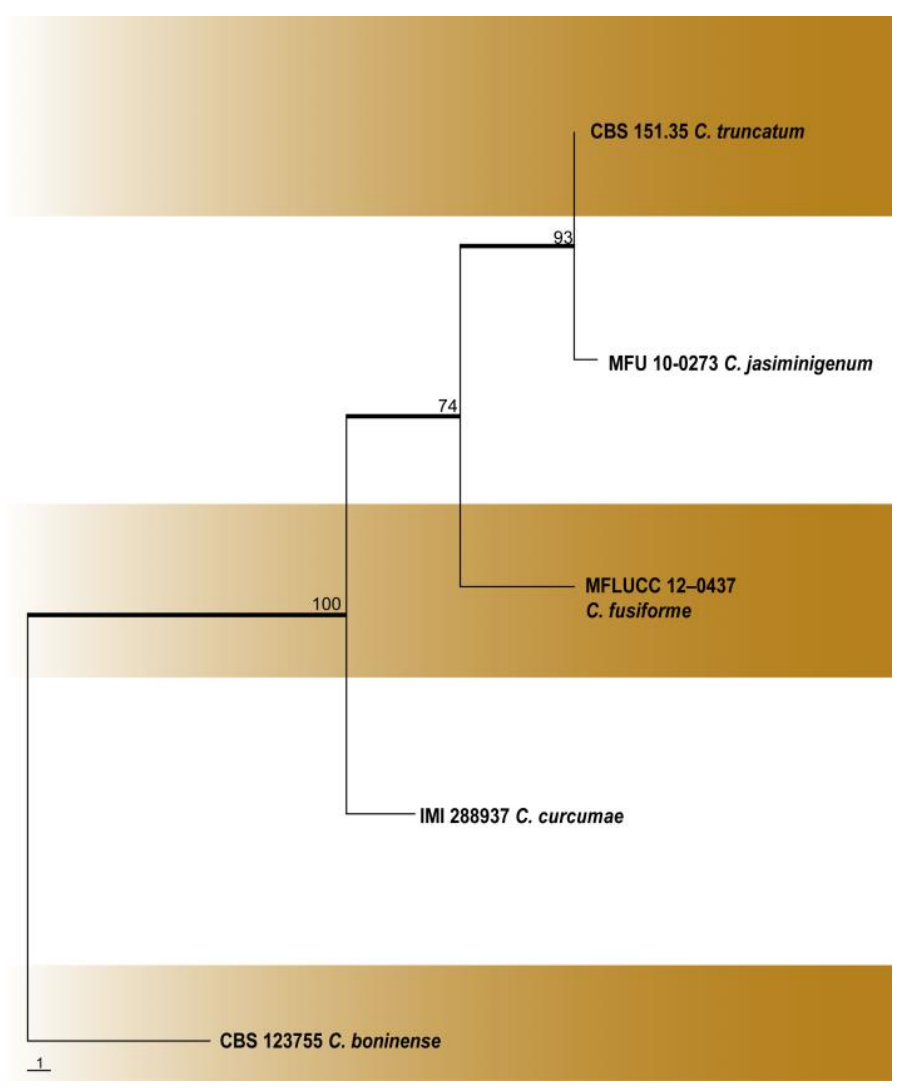

Fig. 24 The most parsimonious tree obtained from a heuristic search of combined ITS, GAPDH, CHS-1, ACT, HIS3 and TUB2 sequence data of taxa from the truncatum species complex. Parsimony bootstrap support values above $50 \%$ are indicated at the nodes and branches with Bayesian posterior probabilities above 0.95 are given in bold. The ex-type strains are in bold. The tree is rooted with $C$. boninense CBS 123755. 


\section{Other taxa}

There are several species that do not belong to any of these species complexes. These species are referred in this paper as singleton species, following the term used in Hyde et al. (2014).

\section{Accepted species of Colletotrichum with notes}

\section{Colletotrichum abscissum Pinho \& O.L. Pereira, Persoonia, Mol. Phyl. Evol. Fungi 34: 237}

(2015)

This species has been recorded as a pathogen on Citrus sinensis causing postbloom fruit drop disease and on Psidium guajava in Brazil and the USA (Crous et al. 2015, Bragança et al. 2016). Colletotrichum abscissum belongs to the acutatum species complex and is phylogenetically closely related to C. tamarilloi and C. costaricense (Crous et al. 2015).

2. Colletotrichum acerbum Damm, P.F. Cannon \& Crous, Stud. Mycol. 73: 43 (2012)

This taxon causes bitter rot of Malus domestica in New Zealand and seems to be endemic (Damm et al. 2012b). Colletotrichum acerbum belongs to the acutatum species complex and is a sister taxon to C. rhombiforme (Damm et al. 2012b). According to Damm et al. (2012b) this species can distinguished most effectively with TUB2 and ITS.

3. Colletotrichum acutatum J.H Simmonds, Queensland J. agric. Anim. Sci. 22: 458 (1965)

This taxon mainly causes fruit rots on a wide range of plants including the families Anacardiaceae, Apocynaceae, Campanulaceae, Caricaceae, Fabaceae, Oleaceae, Pinaceae, Plumbaginaceae, Polemoniaceae, Proteaceae, Ranunculaceae, Rosaceae, Rubiaceae, and Solanaceae worldwide (Damm et al. 2012b). Colletotrichum acutatum is the representative species of the acutatum species complex, and can be seperated with the use of any of the genes (ITS, GAPDH, CHS-1, HIS3, ACT or TUB2) used in Damm et al. (2012b).

4. Colletotrichum aenigma B. Weir \& P.R. Johnst., Stud. Mycol. 73: 135 (2012)

This species belongs to the gloeosporioides species complex and has been recorded as a pathogen on Camellia sinensis in China (Wang et al. 2016), Persea americana in Israel, Pyrus pyrifolia in Japan (Weir et al. 2012), Olea europaea in Italy, Poplar sp. in China and the USA, and on Vitis vinifera in China (Schena et al. 2014, Yan et al. 2015). Colletotrichum aenigma can be distinguished with the use of TUB2 or GS gene sequences (Weir et al. 2012).

5. Colletotrichum aeschynomenes B. Weir \& P.R. Johnst., Stud. Mycol. 73: 135 (2012)

Colletotrichum aeschynomenes has been recorded only from the USA and is a pathogen of Aeschynomene virginica (Weir et al. 2012). It belongs to the musae clade of the gloeosporioides species complex and is genetically close to $C$. siamense. This species can be distinguished with the use of TUB2, GAPDH or GS gene sequences (Weir et al. 2012). Colletotrichum aeschynomenes has been developed as a weed control agent named "Collego" (Ditmore et al. 2008).

6. Colletotrichum agaves Cavara, Fung. Long. Exsicc. 3: no. 100 (1892)

It has been recorded as a pathogen on Agave species in Cuba, El Salvador, Haiti, Italy, Jamaica, Mexico, the Netherlands and the USA (Farr et al. 2006). ITS sequence data show this taxon to be a distinctive singleton species and can be easily distingished from the other Colletotrichum species on Agavaceae by the conidiomata with numerous black setae (Farr et al. 2006).

7. Colletotrichum alatae B. Weir \& P.R. Johnst., Stud. Mycol. 73: 135 (2012)

Colletotrichum alatae has been recorded from India and Nigeria as a pathogen of Yam (Dioscorea alata) (Weir et al. 2012). This species belongs to the gloeosporioides species complex. ITS sequence data can distinguish $C$. alatae from all other taxa (Weir et al. 2012).

8. Colletotrichum alcornii J.A. Crouch, IMA Fungus 5(1):27 (2014)

This taxon is known as a pathogen on Imperata cylindrica and Bothriochloa bladhii in Australia and belongs to the caudatum species complex (Crouch 2014). This species can be identified using any of the gene regions (Apn2, ITS, Sod2, Mat/Apn2) used in Crouch (2014).

9. Colletotrichum alienum B. Weir \& P.R. Johnst., Stud. Mycol. 73: 139 (2012)

This species is known from a wide range of introduced fruit crops such as Banksia dryandroides, Camellia sinensis, Diospyros kaki, Grevillea sp., Leucospermum sp., Malus domestica, Nerium 
oleander, Persea americana, Protea sp., Serruria sp. and Telopea sp. in Australia, China, Hawaii, New Zealand, Portugal, South Africa and Zimbabwe (Weir et al. 2012, Crous et al. 2013a, Liu et al. 2013b, 2015a, Schena et al. 2014). Colletotrichum alienum cannot be distinguished by morphological characters; ITS sequences do not separate it from $C$. siamense isolates. This taxon is best distinguished using CAL or GS gene regions (Weir et al. 2012, Liu et al. 2015a). It belongs to the gloeosporioides species complex.

10. Colletotrichum americae-borealis Damm, in Damm, O'Connell, Groenewald \& Crous, Stud. Mycol. 79: 55 (2014)

This taxon belongs to the destructivum species complex and has been recorded only as a pathogen on Medicago sativa in the USA (Damm et al. 2014). Conidial shape of this species is similar to the conidia of $C$. lini, but it differs in having more complex appressoria. In contrast with most species of the destructivum complex, setae of this species are very abundant (Damm et al. 2014). TUB2, CHS-1, HIS3 and ACT sequence data can be used to distinguish it from other species in the destructivum complex (Damm et al. 2014).

11. Colletotrichum annellatum Damm, P.F. Cannon \& Crous, Stud. Mycol. 73: 6 (2012)

This species has been recorded from Hevea sp. in Colombia. As its name suggests, C. annellatum produces conidiogenous cells that have annellid-like proliferations (Damm et al. 2012a). It belongs to the boninense species complex and is sister to the clade that contains C. citricola, C. karstii and C. phyllanthi (Damm et al. 2012a).

12. Colletotrichum anthrisci Damm, P.F. Cannon \& Crous, in Damm, Woudenberg, Cannon \& Crous, Fungal Diversity 39: 56 (2009)

Colletotrichum anthrisci is only known from Anthriscus sylvestris in the Netherlands (Damm et al. 2009). It belongs to the dematium species complex and has angular conidia, in which the apex is strongly pointed (Damm et al. 2009). This species differs from other species in this complex in having a constricted base of setae and very long, navicular appressoria (Damm et al. 2009, Yang et al. 2012a). Colletotrichum anthrisci has been found in association with stem lesions, as well as on dead stems of Anthriscus sylvestris.

13. Colletotrichum antirrhinicola Damm, in Damm, O'Connell, Groenewald \& Crous, Stud. Mycol. 79: 56 (2014)

It is only known from a leaf of Antirrhinum majus in New Zealand (Damm et al. 2014). Colletotrichum antirrhinicola belongs to the destructivum complex and can be identified by its unique GAPDH and ITS sequence data.

14. Colletotrichum aotearoa B. Weir \& P.R. Johnst., Stud. Mycol. 73: 139 (2012)

Colletotrichum aotearoa is known from Australia, India, Taiwan and New Zealand (Weir et al. 2012, Liu et al. 2013b, Sharma et al. 2015, Hsiao et al. 2016). It is common on taxonomically diverse native plants (Banksia marginata, Bredia oldhamii, Coprosma sp., Dacrycarpus dacrydioides, Knightia sp., Musa sp., Podocarpus totara and Vitex lucens) as a pathogen causing fruit rot and also as an endophyte on naturalized weeds (Boehmeria sp.) (Weir et al. 2012, Liu et al. 2013b, Tao et al. 2013, Sharma et al. 2015, Hsiao et al. 2016). An endophytic strain (BCRC 09F0161) of this species from leaves of Bredia oldhamii, is capable of producing 18 secondary metabolites (Hsiao et al. 2016). Colletotrichum aotearoa belongs to the kahawae clade of the gloeosporioides species complex. This species is morphologically indistinguishable from $C$. kahawe subsp. ciggaro. It can be phylogenetically distinguished with TUB2, CAL, GS and GAPDH sequence data (Weir et al. 2012). Sharma et al. (2015) showed that this species can be well-resolved from other species of the gloeosporioides complex with the ApMat gene region.

15. Colletotrichum aracearum LW. Hou \& L. Cai, Mycosphere 7(8): 1115 (2016)

This species has been recorded from Monstera delociosa and Philodenron selloum in China (Hou et al. 2016). It is a singleton species with close affinity to $C$. cliviae. Sexual morph of this species has been observed.

16. Colletotrichum arxii F. Liu, L. Cai, Crous \& Damm, Persoonia, Mol. Phyl. Evol. Fungi 33: 87 (2014) 
This species is known as an endophyte on Oncidium excavatum in the Netherlands and on Paphiopedilum sp. in Germany (Liu et al. 2014). Colletotrichum arxii belongs to the gigasporum species complex and can be identified with ITS and TUB2 sequences.

17. Colletotrichum asianum Prihastuti, L. Cai \& K.D. Hyde, Fungal Diversity 39: 96 (2009)

This taxon is known as a pathogen of Mangifera indica in Australia (Rojas et al. 2010), Brazil (Lima et al. 2013, Veira et al. 2014a), Colombia (Afanador-Kafuri et al. 2003, Hoz et al. 2016), Ghana (Honger et al. 2014), India (Liu et al. 2015a), Japan, Malaysia, Panama, the Philippines, South Africa, Sri Lanka and Thailand. It is also reported to cause anthracnose on Capsicum annuum in Laos (Phoulivong et al. 2010) and reported as a pathogen of Coffea arabica in Thailand (Weir et al. 2012, Krishnapillai \& Wijeratnam 2014, Sharma et al. 2013, 2015, Zakaria et al. 2015).Colletotrichum asianum belongs to the gloeosporioides species complex (Weir et al. 2012). This species can be distinguished by all other taxa using ITS or any of the genes tested (ACT, TUB2, CAL, CHS-1, GAPDH) in Weir et al. (2012).

18. Colletotrichum australe Damm, P.F. Cannon \& Crous, Stud. Mycol. 73 : 57 (2012)

This species is a pathogen on Trachycarpus fortunei in Australia and Hakea sp. in South Africa (Damm et al. 2012b). It belongs to the acutatum species complex and can be distinguished with ITS, TUB2, ACT and HIS3 sequences; most effectively with HIS3 (Damm et al. 2012b).

19. Colletotrichum axonopodi J.A. Crouch, B.B. Clarke, J.F. White \& B.I. Hillman, Mycologia 101(5): 727 (2009)

This species has a unique association with the temperate grass, Axonopus and has been reported as a pathogen on Axonopus in Australia and Honduras, Georgia and Louisiana states of the USA (Crouch et al. 2009a). It is morphologiacally similar to other Colletotrichum species associated with grasses and is sister to the clade that contains $C$. echinochloae, $C$. hanaui and $C$. jacksonii belonging to the graminicola complex (Crouch et al. 2009a).

20. Colletotrichum baltimorense J.A. Crouch, IMA Fungus 5(1): 27 (2014)

This taxon has only been recorded as a pathogen on leaves of Sorghastrum nutans in the USA (Crouch 2014). Colletotrichum baltimorense belongs to the caudatum species complex. This species can be identified using any of the gene regions (Apn2, ITS, Sod2, Mat/Apn2) used in Crouch (2014).

21. Colletotrichum beeveri Damm, P.F. Cannon, Crous, P.R. Johnst \& B. Weir, Stud. Mycol. 73: 9 (2012)

This species has been recorded as a pathogen of Brachyglottis repanda in New Zealand (Damm et al. 2012a), as well as an endophyte of Pleione bulbocodioides and possibly also of Podocarpaceae in China (Damm et al. 2012a, Yang et al. 2011). Colletotrichum beeveri belongs to the boninense species complex and forms a sister group to $C$. brassicicola and $C$. colombiense (Damm et al. 2012a). It can be distinguished by any of the gene regions used in Damm et al. (2012a) except for ITS and GAPDH.

22. Colletotrichum bidentis Damm, Guatimosim \& Vieira, Fungal Diversity 61: 34 (2013)

This species is pathogenic on Bidentis sp. in Brazil and belongs to the orbiculare species complex. This taxon can be distinguished from the other species in the orbiculare species complex by its slightly curved conidia and setae with a conspicuous white tip (Damm et al. 2013) and it can be distinguished with the use of GS or GAPDH gene sequences.

23. Colletotrichum bletillae G. Tao, Zuo Y. Liu \& L. Cai [as 'bletillum'], in Tao, Liu, Liu, Gao \& Cai, Fungal Diversity 61: 144 (2013)

This species is an endophyte of Bletilla ochracea in China, and belongs to the spaethianum species complex (Tao et al. 2013). Colletotrichum bletillum closely related to C. liriopes (Tao et al. 2013). It can be distinguished by any of the gene regions (ITS, ACT, GAPDH and TUB2) used in Tao et al. (2013).

24. Colletotrichum boninense Moriwaki, Toy. Sato \& Tsuki, Mycoscience 44: 48 (2003)

Colletotrichum boninense is a pathogen and an endophyte, occurring on a high diversity of host plants belonging to Amaryllidaceae, Annonaceae, Bignoniaceae, Lauracea, Olivaceae, Orchidaceae, Piperaceae, Podocarpaceae, Protaceae, Rubiaceae, Rutaceae, Solanaceaea and 
Theaceae (Silva-Rojas et al. 2011, Diao et al. 2013, Feritas et al. 2013, Peng et al. 2012, Tao et al. 2013, Afanador-Kafuri et al. 2014, Alvarez et al. 2014, Mosca et al. 2014). Ascospores of this species are uniform with rounded ends, becoming brown and septate with age (Damm et al. 2012a). It is the reference species of the boninense species complex.

25. Colletotrichum brasiliense Damm, P.F. Cannon, Crous \& Massola, Stud. Mycol. 73: 11 (2012) This species is only known as a pathogen on Passiflora edulis in Brazil (Tozze et al. 2010). Colletotrichum brasiliense belongs to the boninense species complex and is closely related to $C$. parsonsiae and C. hippeastri (Damm et al. 2012a). This taxon can be distinguished from the other species with the use of ACT, GAPDH, ITS and TUB2 sequences (Damm et al. 2012a).

26. Colletotrichum brassicicola Damm, P.F. Cannon \& Crous, Stud. Mycol. 73 : 14 (2012)

The taxon has been reported from leaf spots of Brassica oleraceae in New Zealand (Damm et al. 2012a) and from Rubus glaucus in Colombia (Afanador-Kafuri et al. 2014). It belongs to the boninense species complex and is distinct in having very short conidia and longer asci and ascospores compared to the other species with known sexual morphs in the complex (Damm et al. 2012a). It can be distinguished by any of the gene regions used in Damm et al. (2012a) except for ITS and GAPDH.

27. Colletotrichum brevisporum Noireung, Phouliv., L. Cai \& K.D. Hyde, Cryptog. Mycol. 33(3): 350 (2012)

This species is a pathogen on Carica papaya and Sechium edule in Brazil (Vieira et al. 2013, Bezerra et al. 2016), Citrus medica in China (Peng et al. 2012), and Neoregelia sp. and Pandanus pygmaeus in Thailand (Liu et al. 2014). Colletotrichum brevisporum has been recorded as an endophyte of Lycium chinense in Korea (Paul et al. 2014). It is a singleton species. This taxon forms a sister group to C. cliviae (Noireung et al. 2012, Hyde et al. 2014).

28. Colletotrichum brisbanense Damm, P.F. Cannon \& Crous, Stud. Mycol. 73: 59 (2012)

This pathogenic species is known to cause fruit rot in Capsicum annuum in Australia. It differs from C. scovillei, another anthracnose pathogen of Capsicum annuum, in appressoria size (Damm et al. 2012b). Colletotrichum brisbanense belongs to the acutatum species complex and can be distinguished effectively with the use of TUB2 and GAPDH (Damm et al. 2012b).

29. Colletotrichum bryoniicola Damm, in Damm, O'Connell, Groenewald \& Crous, Stud. Mycol. 79: 57 (2014)

It is a saprobe known from decaying leaves of Bryonia dioica in the Netherlands (Damm et al. 2014). Colletotrichum bryoniicola belongs to the destructivum species complex and can be distinguished from closely related species by its ITS, GAPDH, HIS3 and TUB2 sequence data, as well as by its broader conidia ( $\geq 4 \mu \mathrm{m}$ on SNA) and distinct conidiogenous cells (Damm et al. 2014).

30. Colletotrichum cairnsense D.D. De Silva, R. Shivas \& P.W.J Taylor, Plant pathology http://doi: 10.1111/ppa.12572 (2016)

It is a pathogen of Capsicum annuum in Australia and belongs to the acutatum species complex (De Silva et al. 2016). This species can be distinguish from the other species of the acutatum complex with GAPDH and TUB2 sequence data.

31. Colletotrichum camelliae Massee, Bull. Misc. Inf., Kew: 91 (1899)

This taxon is responsible for causing twig blight and brown blight of Camellia sp. in China, Sri Lanka, the UK and the USA (Liu et al. 2015a, Wang et al. 2016). Colletotrichum camelliae belongs to the kahawae clade within the gloeosporioides complex and can be distinguished with the use of GS and ApMat gene sequences. Glomerella cingulata "f. sp. camelliae" has been synonymized with C. camelliae (Liu et al. 2015a).

32. Colletotrichum camelliae-japonicae LW. Hou \& L. Cai, Mycosphere 7(8): 1117 (2016)

This species is a pathogen on Camellia japonica. It was isolated from $C$. japonica imported from Japan (Hou et al. 2016). C. camelliae-japonicae belongs in the boninense species complex. Sexual morph of this species has been observed.

33. Colletotrichum carthami (Fukui) S. Uematsu, Kageyama, Moriwaki \& Toy. Sato, J. Gen. Pl. Path. 78(5): 326 (2012) 
This species is known to be pathogenic on Calendula officinalis in Italy, Japan (Baroncelli et al. 2015a) and on Carthamus tinctorius causing leaf blight, in Japan (Uematsu et al. 2012), as well as on Chrysanthemum coronarium var. spatiosum in Korea (Uematsu et al. 2012). Colletotrichum carthami belongs in the acutatum species complex (Damm et al. 2012b).

34. Colletotrichum caudatum (Peck ex Sacc.) Peck, Bull. N.Y. St. Mus. 131: 81 (1909)

The distribution of this species is limited to Sorghastrum nutans in the mid-Atlantic states of the USA (Crouch 2014). This taxon belongs to the caudatum species complex and is the representative species of the complex (Crouch 2014). This species can be identified using any of the gene regions (Apn2, ITS, Sod2, Mat/Apn2) used in Crouch (2014).

35. Colletotrichum caudisporum G. Tao, Zuo Y. Liu \& L. Cai [as 'caudasporum'], in Tao, Liu, Liu, Gao \& Cai, Fungal Diversity 61: 149 (2013)

This taxon is an endophyte of Bletilla ochraceae in China (Tao et al. 2013). Colletotrichum caudasporum belongs to the caudatum species complex (this paper). It can be distinguished with the ITS sequences data.

36. Colletotrichum cereale Manns, in Selby \& Manns, Proc. Indiana Acad. Sci.: 111 (1908)

It is a pathogen of grasses (Poaceae) of the subfamily Pooideae in Germany, Japan, New Zealand, the Netherlands and the USA (Young et al. 2008, Crouch \& Inguagiato 2009, Beirn et al. 2014) and an endophyte of Bletilla (Orchidaceae) in China (Tao et al. 2013). This species belongs to the graminicola species complex (Cannon et al. 2012, Hyde et al. 2014).

37. Colletotrichum chengpingense G. Zhang, Jayawardena \& KD Hyde, in Jayawardena et al., Mycosphere 7(8): 1155 (2016)

It is a pathogen on Fragaria $\times$ ananassa in China, belonging to the gloeosporioides species complex (Jayawardena et al. 2016b). This species can be distinguished from its closely related species with any of the gene regions used in Jayawardena et al. (2016b).

38. Colletotrichum chlorophyti S. Chandra \& Tandon [as 'chlorophytumi'], Curr. Sci. 34: 565 (1965)

This species is a pathogen on Chlorophytum sp. in India (Damm et al. 2009), Glycine max in the USA (Yang et al. 2012b) and Stylosanthes hamata in Australia (Damm et al. 2009). Colletotrichum cholophyti has curved conidia and can be distinguished from other species with curved conidia as it has dark brown chlamydospores in chains and clusters (Damm et al. 2009). This is a singleton species (Cannon et al. 2012, Hyde et al. 2014).

39. Colletotrichum chrysanthemi (Hori) Sawada, Rep. Govt Res. Inst. Dep. Agric., Formosa 85: 81 (1943)

This taxon is a pathogen on Chrysanthemum coronarium in China, Japan and the Netherlands causing vascular discoloration and leaf spots (Damm et al. 2012b). It also causes anthracnose on Carthamus tinctorius in Italy (Baroncelli et al. 2015a). This species belongs to the acutatum species complex and differs from all the other species in the complex in having very short, conidia with acute ends and can be phylogenetically best separated with TUB2, GAPDH and HIS3 (Damm et al. 2012b).

40. Colletotrichum circinans (Berk.) Voglino, Annali R. Accad. Agric. Torino 49: 175 (1907)

This species is common in temperate regions as an anthracnose pathogen on Allium sp. It is also a pathogen on Anthriscus sylvestris (Germany), Beta vulgaris (New Zealand), and Viola hirta (Czech Republic) (Damm et al. 2009). Colletotrichum spinaciae is the sister taxon of this species. When compared with $C$. spinaciae, conidia of $C$. circinans are more strongly curved towards the truncate base and acute apex as well as dark brown, concolored seate that are often constricted and sometimes inflated above the constriction (Damm et al. 2009). It is a member of the dematium species complex (Cannon et al. 2012, Hyde et al. 2014).

41. Colletotrichum citri F. Huang, L. Cai, K.D. Hyde \& Hong Y. Li, in Huang, Chen, Hou, Fu, Cai, Hyde \& Li, Fungal Diversity 61(1): 69 (2013)

It is known on Citrus aurantifolia in China causing anthracnose (Huang et al. 2013) and belongs to the acutatum species complex. Huang et al. (2013) mentioned that this species is not common on Citrus. 
42. Colletotrichum citricola F. Huang, L. Cai, K.D. Hyde \& Hong Y. Li, in Huang, Chen, Hou, Fu, Cai, Hyde \& Li, Fungal Diversity 61(1): 67 (2013)

This species has only been reported as a saprobe from Citrus unshiu in China and belongs to the boninense species complex (Huang et al. 2013). Colletotrichum citricola differs from its sister taxon $C$. phyllanthi in having wider conidia (5.9-6.9 $\mu \mathrm{m})$ (Huang et al. 2013).

43. Colletotrichum clidemiae B.S. Weir \& P.R. Johnst., in Weir, Johnston \& Damm, Stud. Mycol. 73: 148 (2012)

This species causes leaf spots on Clidemia hirta, Vitis sp. and Quercus sp. in the USA and belongs to the kahawae clade within the gloeosporioides species complex (Weir et al. 2012). Colletotrichum clidemiae can be distinguished by ACT, GAPDH or GS sequence data (Weir et al. 2012). ApMat sequence data can also be used to distinguish this species within the complex (in this study).

44. Colletotrichum cliviae Yan L. Yang, Zuo Y. Liu, K.D. Hyde \& L. Cai, in Yang, Liu, Cai, Hyde, Yu \& McKenzie, Fungal Diversity 39: 133 (2009)

This taxon causes anthracnose on leaves of Arundina graminifolia, Camelliae sinensis, Clivia miniata and Cymbidium hookerianum in China (Yang et al. 2009, 2011, Wang et al. 2016) and on Cattleya sp., Calamus thwaitesii, Phaseolus sp. and Saccharum sp. in India (Chowdappa et al. 2014). It is also an endophyte on Camellia sinensis and Mangifera indica in Brazil (Vieira et al. 2014a, Liu et al. 2015a). Colletotrichum cliviae forms a monophyletic lineage that is not closely related to any established clade; therefore it is a singleton species (Cannon et al. 2012, Hyde et al. 2014).

45. Colletotrichum coccodes (Wallr.) S. Hughes, Can. J. Bot. 36: 754 (1958)

This species is known as a pathogen on a wide range of plant families including Amaranthaceae, Amaryllidaceae, Apiaceae, Araceae, Araliaceae, Arecaceae, Asteraceae, Cucurbitaceae, Euphorbiaceae, Fabaceae, Iridaceae, Lamiaceae, Malvaceae, Moraceae, Myrtaceae, Poaceae, Solanaceae and Theaceae worldwide (Liu et al. 2011, Liu et al. 2013b, Garibaldi et al. 2015). It is a singleton species.

46. Colletotrichum colombiense Damm, P.F. Cannon \& Crous, Stud. Mycol. 73: 16 (2012)

Colletotrichum colombiense is an endophyte of Passiflora edulis in Colombia. It belongs to the boninense species complex and forms a sister group to C. beeveri (Damm et al. 2012a).

47. Colletotrichum conoides Y.Z. Diao, C. Zhang, L. Cai \& X.L. Liu, Persoonia 38: 27 (2017)

This is a pathogen of Capsicum annuum var. conoides in China. It belongs to the gloeosporioides species complex (Diao et al. 2017). Colletotrichum conoides can be distinguished with the use of GAPDH, ACT and TUB2 sequence data.

48. Colletotrichum constrictum Damm, P.F. Cannon, Crous, P.R. Johnst \& B. Weir, Stud. Mycol. 73: 17 (2012)

This species belongs to the boninense species complex. It causes fruit rots of Citrus limon and Solanum betacum in New Zealand (Damm et al. 2012a). It differs from all other species in this complex by having broader ascospores with a lower L/W ratio (Damm et al. 2012a). This species can be identified with the use of any of the genes used in Damm et al. (2012a).

49. Colletotrichum cordylinicola Phoulivong, L. Cai \& K. D. Hyde, Mycotaxon 114: 251 (2011)

This taxon is a pathogen on Cordyline sp. in Thailand (Sharma et al. 2014) and in the USA and Eugenia sp. in Laos (Weir et al. 2012). Phoulivong et al. (2011) reported that the isolate from Eugenia was not pathogenic to Cordyline and vice versa. Colletotrichum cordylinicola belongs to the gloeosporioides species complex. ITS sequence can separate this species from all other species of this complex (Weir et al. 2012).

50. Colletotrichum cosmi Damm, P.F. Cannon \& Crous, Stud. Mycol. 73: 61 (2012)

Colletotrichum cosmi is a pathogen on the seeds of Cosmos sp. in the Netherlands and belongs to the acutatum species complex (Damm et al. 2012b). It can be distinguished with all loci used in Damm et al. (2012b), best with GAPDH and HIS3.

51. Colletotrichum costaricense Damm, P. F. Cannon \& Crous, Stud. Mycol. 73: 63 (2012) 
This species is pathogenic/endophytic on Coffea sp. in Costa Rica and belongs to the acutatum species complex (Damm et al. 2012b). It can be differentiated from other species with TUB2, GAPDH and ACT sequences, most effectively with TUB2 sequence data (Damm et al. 2012b).

52. Colletotrichum curcumae (Syd. \& P. Syd.) E.J. Butler \& Bisby, Fungi of India: 153 (1931)

This taxon is a pathogen only on Curcuma longa in India (Damm et al. 2009) and belongs to the truncatum species complex (Cannon et al. 2012). Colletotrichum curcumae differs from all other species in producing large, brown, flattened stromata with straight setae that are aggregated in the centre, and with sparse sporulation (Damm et al. 2009).

53. Colletotrichum cuscutae Damm, P.F. Cannon \& Crous, Stud. Mycol. 73: 64 (2012)

Colletotrichum cuscutae was recorded as a pathogen of Cuscuta sp. in Dominica. This species belongs to the acutatum species complex and can be identified using all the genes studied in Damm et al. (2012a) except for ITS; most effectively by TUB2 and ACT sequence data.

54. Colletotrichum cymbidiicola Damm, P.F. Cannon, Crous, P.R. Johnst. \& B. Weir, Stud. Mycol. 73: 19 (2012)

This species is a pathogen on Cymbidium sp. in Australia, India, Japan and New Zealand (Damm et al. 2012a, Chowdappa et al. 2014). Colletotrichum cymbidiicola belongs to the boninense complex and is a sister group to $C$. oncidii (Damm et al. 2012a). It is apparently host-specific at plant genus level (Damm et al. 2012a).

55. Colletotrichum dacrycarpi Damm, P.F. Cannon, Crous, P.R. Johnst. \& B. Weir, Stud. Mycol. 73: 19 (2012)

This taxon is an endophyte of Dacrycarpus sp. in New Zealand. Conidia of this species are produced within closed fruiting bodies with walls that rupture. Colletotrichum dacrycarpi belongs to the boninense species complex and can be identified using ITS sequence data as well as the other gene regions used in Damm et al. (2012a).

56. Colletotrichum dematium (Pers.) Grove, J. Bot., Lond. 56: 341 (1918)

This species occurs as a pathogen, endophyte as well as a saprobe. It has been recorded as a saprobe of Apiaceae in the Czech Republic and Eryngium campestre in France, as a pathogen of Genista tinctoria in the Czech Republic, Solanum tuberosum in Australia (Damm et al. 2009), Bidens pilosa in Cuba, Venezuela and West Indies, (Farr \& Rossman 2016) and as an endophyte on Vitis vinifera in South Africa (Damm et al. 2009). This taxon is characterized by the angular shape of its conidia, the production of red pigments in fresh cultures and by its well developed sclerotium-like conidiomata (Damm et al. 2009).

57. Colletotrichum destructivum O'Gara, Mycologia 7(1): 38 (1915)

Colletotrichum destructivum is a pathogen on hosts in Asteraceae, Convolvulaceae, Fabaceae, Magnoliaceae, Menispermaceae, Lamiaceae, Poaceae, Polygonacea and Solanaceae worldwide (Damm et al. 2014) as well as an endophyte of Bletilla ochraceae in China (Tao et al. 2013). Colletotrichum destructivum belongs to the destructivum species complex and can be distinguished by ITS, HIS3, ACT and TUB2 sequence data (Damm et al. 2014).

58. Colletotrichum dracaenophilum D.F. Farr \& M.E. Palm, in Farr, Aime, Rossman \& Palm, Mycol. Res. 110(12): 1401 (2006)

This species causes leaf anthracnose of Dracaena sp. in Bulgaria, China and Egypt (Farr et al. 2006, Morsy \& Elshahawy 2016). It is a singleton species with close affinity to $C$. yunnanense (Farr et al. 2006, Hyde et al. 2014).

59. Colletotrichum duyunensis G. Tao, Zuo Y. Liu \& L. Cai, in Tao, Liu, Liu, Gao \& Cai, Fungal Diversity 61: 149 (2013)

This taxon is an endophyte on Bletilla ochracea in China (Tao et al. 2013). It belongs to the caudatum species complex (this paper). This species can be distinguished from C. caudasporum by its longer conidial appendages (Tao et al. 2013).

60. Colletotrichum echinochloae Moriwaki \& Tsukib., Mycoscience 50(4): 275 (2009)

It causes leaf blight and leaf spot on Echinochloa esculenta in Japan (Moriwaki \& Tsukiboshi 2009). Colletotrichum echinochloae belongs to the graminicola species complex and is a sister taxon to C. jacksonii (Hyde et al. 2014). 
61. Colletotrichum eleusines Pavgi \& U.P. Singh [as 'eleusinis'], Mycopath. Mycol. appl. 27: 85 (1965)

This species is a pathogen on Eleusine indica in India, Japan and the USA (Crouch et al. 2009a) and belongs to the graminicola species complex (Cannon et al. 2012, Hyde et al. 2014). It is morphologically indistinguishable from the other closely related falcate-spored, grass inhabiting Colletotrichum species, but ITS, SOD2, Apn2 and Mat1 sequence data can be used to distinguish this species (Crouch et al. 2009a).

62. Colletotrichum endophytica Manamgoda, Udayanga, L. Cai \& K.D. Hyde, in Manamgoda, Udayanga, Cai, Chukeatirote \& Hyde, Fungal Diversity 61:110 (2013)

This is an endophytic species on healthy leaves of Pennisetum purpureum in Thailand (Manamgoda et al. 2013) and was also found as a saprobe on an undetermined wild fruit in Thailand (Udayanga et al. 2013). Wang et al. (2016) recorded this taxon as a pathogen on Camellia sinensis. Colletotrichum endophytica belongs to the gloeosporioides species complex and placed in between the musae and kahawae clades (Manamgoda et. al. 2013).

63. Colletotrichum endophytum G. Tao, Zuo Y. Liu \& L. Cai, in Tao, Liu, Liu, Gao \& Cai, Fungal Diversity 61(1): 152 (2013)

It is an endophyte on Bletilla ochracea in China (Tao et al. 2013). This species belongs to the graminicola species complex (Hyde et al. 2014) and is a sister taxon of C. falcatum. Colletotrichum endophytum has shorter conidia $(8.5-21.5 \times 3-5 \mu \mathrm{m})$ than $C$. falcatum $(15.5-26.5 \times 4-5 \mu \mathrm{m})$. Colletotrichum endophytum also produces relatively abundant seta and more strongly falcate conidia than C. falcatum (Tao et al. 2013).

64. Colletotrichum eremochloae J.A. Crouch \& Tomaso-Pet., Mycologia 104(5): 1092 (2012)

This species belongs to the graminicola species complex and has been recorded as a pathogen of Eremochloa ophiuroides in China and the USA (Crouch \& Tomaso-Peterson 2012).

65. Colletotrichum euphorbiae Damm \& Crous, in Crous et al., Persoonia, Mol. Phyl. Evol. Fungi 31: 203 (2013)

This species is a pathogen on leaves of Euphorbia sp. in South Africa. Colletotrichum euphorbiae forms cylindrical to clavate conidia with one end rounded and one end truncate that are larger $(>20$ $\mu \mathrm{m})$ than those of $C$. sansevieriae and species in the orbiculare complex, which have similar shapes, often in closed fruiting bodies (Crous et al. 2013b). It is a singleton species.

66. Colletotrichum excelsum-altitudinum G. Tao, Zuo Y. Liu \& L. Cai [as 'excelsum-altitudum'], in Tao, Liu, Liu, Gao \& Cai, Fungal Diversity 61: 152 (2013)

This taxon is an endophyte of Bletilla ochracea in China, and a singleton species with close affinity to C. tropicicola (Tao et al. 2013).

67. Colletotrichum falcatum Went, Archiv, voor de Java Suekerrind. 1: 265 (1893)

It is a pathogen of Saccharum officinarum (Poaceae) in Australia, Indonesia, Japan, the Netherlands and Thailand (Cai et al. 2009, Crouch et al. 2009a, Crouch 2014, Prihastuti et al. 2009, 2010). It belongs to the graminicola species complex (Cannon et al. 2012).

68. Colletotrichum fioriniae (Marcelino \& Gouli) R.G. Shivas \& Y.P. Tan, Fungal Diversity 39: 117 (2009)

Colletotrichum fioriniae causes fruit rot and leaf spots on Acacia acuminate, Actinidia chinensis, Anemone sp., Berberis sp., Camellia reticulata, Camellia sinensis, Carica papaya, Cinnamomum subavenium, Coffea arabica, Cyclamen sp. Fragaria×ananassa, Grevillea sp., Kalmia sp., Liriodendron tulipifera, Magnolia sp., Malus sp., Olea europea, Parthenocissus sp., Penstemon sp., Persea americana, Piper nigrum, Primula sp., Pyrus sp., Rhododendron sp., Rubus sp., Solanum lycopersicum, Toxicondendron radians, Tulipa sp., Vaccinium sp. and Vitis vinifera in Australia, China, Germany, Hawaii, Italy, the Netherlands, New Zealand, the UK and the USA (Shivas \& Tan 2009, Sun et al. 2012, Damm et al. 2012b, Baroncelli et al. 2015b, Kasson et al. 2014, Kou et al. 2014, Munda 2014, Liu et al. 2015a, Wang et al. 2016). This species is also an endophyte of Mangifera indica in Australia. Colletotrichum fioriniae is pathogenic on the hemlock scale insect, Fiorinia extrerna, in the USA (Marcelino et al. 2008). It belongs to the acutatum species complex and can be distinguished using any of the gene sequences mentioned in Damm et al. (2012b). 
Kasson et al. (2014) have shown that $C$. fioriniae can be used as a mycoherbicide against Eastern Poison Ivy (Toxicodendron radicans).

69. Colletotrichum fructi (F.Stevans \& J.G. Hall) Sacc. [as 'fructus'], Syll. fung. (Abellini) 22: 1201 (1913)

This species belongs to the dematium species complex (Cannon et al. 2012) and is a pathogen on Malus sylvestris in the USA (Damm et al. 2009). This taxon is slow growing and has been mentioned very rarely in the literature (Damm et al. 2009).

70. Colletotrichum fructicola Prihastuti, L. Cai \& K.D. Hyde, Fungal Diversity 39: 96 (2009)

Colletotrichum fructicola was originally reported from coffee berries in Thailand (Prihastuti et al. 2009). It has a wide host range and geographical distribution including Arachis sp. (Fabaceae), Citrus bergamia (Rutaceae) in China (Peng et al. 2012), Cymbopogon citrates (Poaceae) in Thailand (Manamgoda et al. 2013), Dioscorea alata in Nigeria, Ficus sp. (Dioscoreaceae) in Germany, Fragaria $\times a n a n a s s a$ (Rosaceae) in Canada and the USA, Limonium sp. (Plumbaginaceae) in Israel, Malus domestica (Rosaceae) in Australia, Brazil and Uruguay (Weir et al. 2012, Velho et al. 2015), Mangifera indica (Anacardiaceae) in India and Brazil (Liu et al. 2015a, Viera et al. 2014), Persea americana (Lauraceae) in Australia, Pyrus pyrifolia (Rosaceae) in Japan, Theobroma cacao (Malvaceae) and Tetragastris panamensis (Burseraceae) in Panama, Pennisetum purpureum (Poaceae) in Thailand (Manamgoda et al. 2013), and Camellia sinensis (Wang et al. 2016), Rubus glaucus (Rosaceae) and Vitis vinifera (Vitaceae) in China (Peng et al. 2013) (Yang et al. 2009, Afanador-Kafuri et al. 2014). This species also occurs as an endophyte. Colletotrichum fructicola belongs to the musae clade in the gloeosporioides species complex. ITS sequences do not separate this taxon from $C$. aeschynomenes. However, these species can be distinguished by GS or SOD2 sequences (Weir et al. 2012).

71. Colletotrichum fructivorum V.P. Doyle, P.V. Oudem. \& S.A. Rehner, PLoS ONE 7(12): e51392, 12 (2012)

This taxon is pathogenic to Vaccinium sp. in Canada, Colombia and the USA (Doyle et al. 2013). Doyle et al. (2013) reported this species as an endophyte on Rhexia virginica and Vaccinium macrocarpon in the USA. It belongs to the gloeosporioides species complex (Doyle et al. 2013, Hyde et al. 2014).

72. Colletotrichum fuscum Laubert, Gartenwelt 31: 675 (1927)

This species causes anthracnose on Digitalis sp.Germany and the Netherlands (Damm et al. 2014). Colletotrichum fuscum belongs to the destructivum species complex. It can be distinguished from the other species in the complex by GAPDH sequence data, but has only one nucleotide difference from C. bryoniicola (Damm et al. 2014).

73. Colletotrichum fusiforme Jayawardena, Bhat, Tangthirasunun \& K.D. Hyde, in Ariyawansa et al., Fungal Diversity 75(1): 158 (2015)

Colletotrichum fusiforme belongs to the truncatum species complex and was isolated from a dead leaf of an undetermined host in Thailand. Colletotrichum curcumae is a sister taxon of this species (Ariyawansa et al. 2015).

74. Colletotrichum gigasporum E.F. Rakotoniriana \& F. Munaut, in Rakotoniriana, Scauflaire, Rabemanantsoa, Urveg-Ratsimamanga, Corbisier, Quetin-Leclercq, Declerck \& Munaut, Mycol. Progr. 12(2): 407 (2013)

This species is a pathogen of Acacia auriculiformis in Thailand, Centella asiatica in Madagascar, Coffea sp. in Vietnam, Diospyros kaki and Musa sp. in Japan, Persea americana in Sri Lanka, Theobroma cacao, Trichilia tuberculata and Virola surinamensis in Panama and Solanum betaceum in New Zealand (Rakotoniriana et al. 2013, Liu et al. 2014, Wijesundera et al. 2015). Colletotrichum thailandicum has been synonimized with this taxon (Liu et al. 2014). Colletotrichum gigasporum belongs to the gigasporum species complex and is characterized by large conidia. This species had also been isolated from a phaeohyphomycotic cyst of a human (Liu et al. 2014). It can be distinguished with all loci (ITS, ACT, TUB2, CHS-1 and GAPDH) used in Liu et al. (2014). 
75. Colletotrichum gloeosporioides (Penz.) Penz. \& Sacc., Atti Inst. Veneto Sci. lett., ed Arti, Sér. 6 (2): 670 (1884)

Colletotrichum gloeosporioides is mainly a pathogen of Citrus sp., but also occurs on Carya illinoinensis (Australia), Ficus sp. (New Zealand), Mangifera sp. (China and South Africa), Solanum betaceum (Colombia), Pureraria sp. (USA) and Vitis vinifera (China and the USA) (Phoulivong et al. 2010, Peng et al. 2012, Weir et al. 2012, Hoz et al. 2016, Rhaiem \& Taylor 2016). Previously, about 600 species were synonymised with this species (von Arx 1957) and consequently, numerous taxa were named as $C$. gloeosporioides, and thus it has a wide host range in many publications (Farr \& Rossman 2016). Weir et al. (2012) did a comprehensive study on $C$. gloeosporioides and related species, resolving most of the species under the name of $C$. gloeosporioides. ITS gene region separates this group from all other species.

76. Colletotrichum godetiae Neerg., Friesia 4(1-2): 72 (1950) [1949-50]

This species was initially described from seeds of Clarkia (syn. Godetia) and causes leaf spots, fruit rots, die back and stem end rots of many hosts in the families of Adoxaceae, Anacardiaceae, Berberidaceae, Fabaceae, Juglandaceae, Myrtaceae, Oleaceae, Onagraceae, Podocarpaceae, Rosaceae, Rhamnaceae, Rutaceae, Solanaceae and Vitaceae worldwide (Damm et al. 2012b , Afanador-Kafuri et al. 2014, Baroncelli et al. 2014, 2015b, Mosca et al. 2014, Munda 2014, Talhinhas et al. 2015). It has been also recorded as a saprobe of Laurus nobilis (Damm et al. 2012b). Colletotrichum godetiae belongs to the acutatum species complex and can be seperated from the other species of this complex by all genes used in Damm et al. (2012b) except CHS-1; TUB2, ACT and HIS3 sequences separate this species best.

77. Colletotrichum graminicola (Ces.) G.W. Wilson, Phytopathology 4: 110 (1914)

Colletotrichum graminicola is a pathogen of Zea mays (Crouch et al. 2009a), belonging to the graminicola complex (Cannon et al. 2012). Whole-genome sequencing of this species has been completed (O'Connell et al. 2012). It has been known to be pathogenic on humans (Ritterband et al. 1997).

78. Colletotrichum grevilleae F. Liu, Damm, L. Cai \& Crous, Fungal Diversity 61: 98 (2013)

This species is a pathogen of Grevillea sp. in Italy (Liu et al. 2013b). Colletotrichum grevilleae belongs to the gloeosporioides species complex and has a close affinity with $C$. theobromicola. However, these species can be distinguished based on CAL and GAPDH sequence data (Liu et al. 2013b).

79. Colletotrichum grossum Y.Z. Diao, C. Zhang, L. Cai \& X.L. Liu, Persoonia 38: 29 (2017)

It is a pathogen on Capsicum annuum var. grossum in China (Diao et al. 2017). Colletotrichum grossum belongs to the gloeosporioides species complex and is phylogenetically closely related to C. theobromicola. This species can be distinguished with the use of GAPDH, ACT and TUB2 sequence data.

80. Colletotrichum guajavae Damm, P.F. Cannon \& Crous, Stud. Mycol. 73: 69 (2012)

This taxon is a pathogen of Psidium guajavae in India, and belongs to the acutatum species complex (Damm et al. 2012b). It can be distinguished from other species by TUB2, ACT and GAPDH sequence data; most effectively by GAPDH (Damm et al. 2012b).

81. Colletotrichum guizhouensis G. Tao, Zuo Y. Liu \& L. Cai, in Tao, Liu, Liu, Gao \& Cai, Fungal Diversity 61: 152 (2013)

Colletotrichum guizhouensis is an endophyte of Bletilla ochracea (Tao et al. 2013) and Phlegmariurus phlegmaria in China (Zhang et al. 2015). It belongs to the spaethianum species complex and is a sister taxon to C. spaethianum (Hyde et al. 2014). Zhang et al. (2015) showed that this species is capable of producing Huperzine A.

82. Colletotrichum hanaui J.A. Crouch, B.B. Clarke, J.F. White \& B.I. Hillman, Mycologia 101(5): 728 (2009)

This species has a unique association with grasses in the genus Digitaria and has been reported in China, Japan and the USA (Crouch et al. 2009a,b, Cannon et al. 2012). Colletotrichum hanaui is a pathogen belonging to the graminicola species complex (Cannon et al. 2012). Nucleotide polymorphisms in ITS, SOD2, Apn2 and Mat1 can be used to differentiate this taxon (Crouch et al. 
2009a). Zhao et al. (2013) showed that this species can be used as a bio-control agent on Digitaria sanguinalis.

83. Colletotrichum hebeiense X.H. Li, Y. Wang, K.D. Hyde, M.M.R.S. Jayawardena \& J.Y. Yan, in Yan, Jayawardena, Goonasekara, Wang, Zhang, Liu, Huang, Wang, Shang, Peng, Bahkali, Hyde \& Li, Fungal Diversity 71: 241 (2015)

This is a pathogen on Vitis vinifera in China. It belongs to the gloeosporioides species complex and has a close affinity to C. aenigma (Yan et al. 2015).

84. Colletotrichum hemerocallidis Yan L. Yang, Zuo Y. Liu, K.D. Hyde \& L. Cai, Tropical Plant Pathology 37(3): 170 (2012)

This taxon was isolated from a dead stalk of Hemerocallis sp. in Canada and China (Damm et al. 2009, Yang et al. 2012a). It is a member of the dematium species complex (Hyde et al. 2014).

85. Colletotrichum henanense F. Liu \& L. Cai, in Liu, Weir, Damm, Crous, Wang, Liu, Zhang \& Cai, Persoonia, Mol. Phyl. Evol. Fungi 35: 80 (2015)

Colletotrichum henanense is a pathogen known on Camillia sinensis and Cirsium japonicum in China. This taxon belongs to the gloeospoirioides species complex and can be distinguished by TUB2, ApMat and GS sequence data (Liu et al. 2015a).

86. Colletotrichum higginsianum Sacc., in Higgins, Riv. Accad. di Padova 33: 161 (1917)

Colletotrichum higginasianum causes anthracnose on a wide range of Brassicaceae hosts in Italy, Japan, Korea, Trinidad and Tobago and the USA (Damm et al. 2014). This species belongs to the destructivum species complex and can be distinguished with TUB2 and ITS sequence data (Damm et al. 2014). Whole-genome sequencing of this species has been completed (O'Connell et al. 2012).

87. Colletotrichum hippeastri Yan L. Yang, Zuo Y. Liu, K. D. Hyde \& L. Cai, Fungal Diversity 39: 133 (2009)

This taxon is an endophyte on leaves of Hippeastrum sp. in China and the Netherlands (Damm et al. 2012a). Colletotrichum hippeastri is an outlying species in the boninense clade and can be distinguished from related species by any of the loci used in the study of Damm et al. (2012a).

88. Colletotrichum horii B. Weir \& P.R. Johnst., Mycotaxon 111: 211 (2010)

Colletotrichum horii is associated with fruit and stem disease of Diospyros kaki in Brazil, China, Japan and New Zealand (Weir \& Johnston 2010, Weir et al. 2012, De Mio et al. 2015). Colletotrichum horii belongs to the gloeosporioides species complex and ITS gene region distinguishes it from all other species (Weir et al. 2012).

89. Colletotrichum hsienjenchang I. Hino \& Hidaka, Bull. Miyazaki Coll. Agric. Forest. 6: 93-99 (1934)

This species is a pathogen only on Phyllostachys sp. in Japan (Sato et al. 2012). Combined phylogenetic analysis of ITS, CHS, ACT and HIS3 places this taxon as a singleton species closely related to $C$. metake (in this study). Sato et al. (2012) mentioned it as a rare species. In order to fix the name of this species, it still needs to be epitypified.

90. Colletotrichum hymenocallidicola Chethana, Tangthir., Jayawardena. \& K.D. Hyde, in Ariyawansa et al., Fungal Diversity 75(1): 160 (2015)

This taxon is a pathogen on Hymenocallis sp. in Thailand. It appears as a singleton species with close affinity to $C$. brevisporum. (Ariyawansa et al. 2015).

91. Colletotrichum incanum H.C. Yang, J.S. Haudenshield \& G.L. Hartman, Mycologia 106(1): 38 (2014)

It is a pathogen on Glycine max and Solanum lycopersicum in the USA and on Phaseolus vulgaris in Canada (Yang et al. 2014, Hacquard et al. 2016), Raphanus sativus in Japan (Sato et al. 2005) and can also infect Arabidopsis thaliana (Hacquard et al. 2016). Colletotrichum incanum belongs to the spaethianum species complex (Hyde et al. 2014).

92. Colletotrichum indonesiense Damm, P.F. Cannon \& Crous, Stud. Mycol. 73: 71 (2012)

This taxon causes leaf spots on Eucalyptus sp. in Indonesia (Damm et al. 2012b). It belongs to the acutatum species complex and can be seperated from other species by TUB2, ACT, GAPDH and CHS-1 sequences; most effectively with TUB2. 
93. Colletotrichum insertae Jayawardena, Bulgakov \& K.D. Hyde, in Hyde et al., Fungal Diversity 80: 176 (2016)

It is a saprobic on dying twigs and leafs of Parthenocissus inserta in Russia. Colletotrichum insertae falls within the dematium species complex.

94. Colletotrichum jacksonii J.A. Crouch, B.B. Clarke, J.F. White \& B.I. Hillman, Mycologia 101(5): 729 (2009)

It is a pathogen of the genus Echinochloa in Japan and the USA (Crouch et al. 2009a). Colletotrichum jacksonii belongs to the graminicola species complex.

95. Colletotrichum jasminigenum Wikee, K.D. Hyde, L. Cai \& McKenzie, in Wikee, Cai, Pairin, McKenzie, Su, Chukeatirote, Thi, Bahkali, Moslem, Abdelsalam \& Hyde, Fungal Diversity 46(1): 174 (2011)

Colletotrichum jasminigenum belongs to the truncatum species complex and is known only from Jasminium sambac in Vietnam (Wikee et al. 2011, Hyde et al. 2014).

96. Colletotrichum jiangxiense F. Liu and L. Cai, Persoonia 35: 82 (2015)

This species is a pathogen as well as an endophyte on Camellia sinensis in China. It belongs to the gloeosporioides species complex and is closely related to C. kahawae s.l.. Colletotrichum jiangxiense can be distinguished by GS gene sequences (Liu et al. 2015a).

97. Colletotrichum johnstonii Damm, P.F. Cannon \& Crous, Stud. Mycol. 73: 72 (2012)

This species is a pathogen on Citrus sp. and Solanum lycopersicum, and is thought to be endemic to New Zealand. It belongs to the acutatum species complex and can be differentiated from other species by ACT, HIS3, TUB2 and GAPDH, most effectivey with ACT gene sequences (Damm et al. 2012b).

98. Colletotrichum kahawae J.M Waller \& Bridge, Mycol. Res. 97(8): 993 (1993)

Colletotrichum kahawae belongs to the gloeosporioides species complex and consists of two subspecies namely C. kahawae subsp. kahawae, which is known only from Coffea sp. in Africa (Waller et al. 1993) and C. kahawae subsp. ciggaro which has a wide host range and wide geographic distribution (Weir et al. 2012). Colletotrichum kahawae subsp. kahawae is important in bio-security (Weir et al. 2012). The two subspecies can be distinguished by GS sequences as $C$. kahawae subsp. kahawae has a 22 bp deletion and a single $\mathrm{C}$ to $\mathrm{T}$ transition (Weir et al. 2012). Colletotrichum kahawae subsp. kahawae cannot utilize citrate or tartrate, while C. kahawae subsp. ciggaro can utilize both of these carbon sources (Weir \& Johnston 2010).

99. Colleotrichum karstii Y.L.Yang, Zuo Y. Liu, K.D. Hyde \& L. Cai, Cryptog. Mycol. 32(3): 241 (2011)

This taxon was first recoported from orchids and is also known from many other host plants causing anthracnose, including Annona cherimola, Anthurium sp., Bombax aquaticum, Camellia sp., Capsicum annunum, Carica papaya, Citrus sp., Clivia miniata, Coffea sp., Cucumis melo, Diospyros australis, Eucalyptus grandis, Malus domestica, Olea europaea, Pistacia vera, Rubus glaucus and also on Bletilla ochracea, Mangifera indica, Quercus salicifolia, Theobroma cacao and Zamia oblique as an endophyte (Damm et al. 2012a, Yang et al. 2011, Peng et al. 2012, Tao et al. 2013, Afanador-Kafuri et al. 2014, Schena et al. 2014, Velho et al. 2015, Wang et al. 2016). Colletotrichum karstii belongs to the boninense species complex and is the most common and geographically distributed species within the complex (Damm et al. 2012a). This species can be identified with the use of any of the genes used in Damm et al. (2012a).

100. Colletotrichum kinghornii Damm, P.F. Cannon \& Crous, Stud. Mycol. 73 : 73 (2012)

This species is a pathogen of Phormium sp. in the UK (Damm et al. 2012b). It belongs to the acutatum species complex and can be effectively separated from other species with the use of HIS3 sequence data (Damm et al. 2012b).

101. Colletotrichum laticiphilum Damm, P.F. Cannon \& Crous, Stud. Mycol. 73: 74 (2012)

Colletotrichum laticiphilum causes anthracnose of Hevea brasiliensis in Colombia, and belongs to the acutatum species complex (Damm et al. 2012b). It can be differentiated most effectively from other species by TUB2 sequences (Damm et al. 2012b).

102. Colletotrichum ledebouriae Crous \& M.J. Wingf, Persoonia 36: 331(2016) 
This taxon causes anthracnose on Ledebouria floridunda in South Africa (Crous et al. 2016). It is closely related to $C$. sansevieriae. Conidia of $C$. sansevieriae are larger $(12.5-32.5 \times 2.8-8.8 \mu \mathrm{m})$ (Nakamura et al. 2006) than those of $C$. ledebouriae and overlap with those of $C$. neosansevieriae $(18-22 \times 5-6 \mu \mathrm{m})($ Crous et al. 2015). It is a singleton species.

103. Colletotrichum lentis Damm, in Damm, O'Connell, Groenewald \& Crous, Stud. Mycol. 79: 65 (2014)

This taxon is a pathogen of Lens culinaris in Canada and on Vicia sativa in China (Damm et al. 2014, Xu \& Li 2015) and was first described as "Glomerella truncata" (Armstrong-Cho \& Banniza 2006). Colletotrichum lentis belongs to the destructivum species complex (Damm et al. 2014).

104. Colletotrichum liaoningense Y.Z. Diao, C. Zhang, L. Cai \& X.L. Liu, Persoonia 38: 34 (2017) This taxon is a pathogen on Capsicum annuum var. conoides in China (Diao et al. 2017). Colletotrichum liaoningense is a singleton species and phylogenetically most closely related to $C$. brevisporum. This species can be distinguished with the use of GAPDH and TUB2 sequence data.

105. Colletotrichum lilii Plakidas ex Boerema \& Hamers, Neth.J1 Pl. Path. 94 (suppl.1): 12 (1988)

This taxon is pathogenic to Lilium sp. causing black scale disease of bulbs in Japan and the Netherlands (Damm et al. 2009). Colletotrichum lilii belongs to the spaethianum species complex (Hyde et al. 2014).

106. Colletotrichum limetticola (R.E. Clausen) Damm, P.F. Cannon \& Crous, Stud. Mycol. 73: 76 (2012)

It is pathogenic to Citrus aurantifolia in Cuba and the USA (Damm et al. 2012b). This taxon belongs to the acutatum species complex and can be seperated from the other species of this complex by TUB2, GAPDH and HIS3, most effectively distinguished by TUB2 sequence data (Damm et al. 2012b).

107. Colletotrichum lindemuthianum (Sacc. \& Magnus) Briosi \& Cavara, Funghi Parass. Piante Colt. od Utili, Fasc. 2: no. 50 (1889)

This species belongs to the orbiculare species complex and is a pathogen restricted to Phaseolus vulgaris and P. coccineus (Fabaceae) (Damm et al. 2013, Liu et al. 2013a).

108. Colletotrichum lineola Corda, in Sturm, Deutschl. Fl., 3 Abt. (Pilze Deutschl.) 3 (12): 41 (1831)

Colletotrichum lineola is the type species of the genus Colletotrichum and was primarily observed on a dead stem of an unknown host of Apiaceae in the Czech Republic (Corda 1831). Colletotrichum lineola is also reported on dead stems of Anthriscus sp., Allium giganteum and Heracleum sp. in the Netherlands, on petioles of Fragaria sp. in Canada, on rotten fruit of Prunus domestica in Czech Republic (Damm et al. 2009). Colletotrichum lineola is pathogenic on Clarkia elegans, Trillium sp. in the USA, Astrantia major in Zimbabwe, Tussilago farfara, Euphorbia egula in Canada, Lupinis polyphyllus in Germany, and Symplocarpus foetidus in the USA (Damm et al. 2009). It belongs to the dematium species complex (Cannon et al. 2012, Hyde et al. 2014) and is characterized by small, compressed acervuli, emerging in rows/lines (Damm et al. 2009).

109. Colletotrichum lini (Westerd.) Tochinai, J. Coll. agric., Hokkaido Imp. Univ. 14(4): 176 (1926)

Colletotrichum lini is a pathogen of Linum sp., Medicago sativa, Nigella sp., Raphanus raphanistrum, Taraxacum sp., Teucrium scorodonia and Trifolium sp.in France, Germany, Ireland, the Netherlands, New Zealand, Tunisia, the UK and the USA (Damm et al. 2014). Colletotrichum lini belongs to the destructivum species complex and can be distinguished by CHS-1, ACT, HIS3 and TUB2 gene regions. Damm et al. (2014) has synonimized $C$. linicola under this species.

110. Colletotrichum liriopes Damm, P.F. Cannon \& Crous, in Damm, Woudenberg, Cannon \&

Crous, Fungal Diversity 39: 71 (2009)

This taxon is known to cause anthracnose on Eria coronaria in China (Yang et al. 2011), Liriope muscari in Mexico (Damm et al. 2009) and Rohdea japonica in Korea (Kwon \& Kim 2013). Tao et al. (2013) reported this species as an endophyte of Bletilla ochracea in China. Also, Yang et al. (2011) reported that $C$. liriopes occurs as an endophyte on Peione bulbocodioides in China and 
isolated this species from a dead stalk of Hemerocallis fulva in China. Colletotrichum liriopes belongs to the spaethanium species complex (Cannon et al. 2012).

111. Colletotrichum lupini (Bondar) Damm, P.F. Cannon \& Crous, Stud. Mycol. 73: 78 (2012)

It is a pathogen on Camellia sp. (UK), Cinnamomum verum (Portugal), Lupinus sp. (Australia, Austria, Bolivia, Canada, Costa Rica, France, Germany, Korea, Netherlands, Poland, South Africa, USA and Ukraine), and Manihot utillissima (Ruwanda) (Damm et al. 2012b, Han et al. 2014, Rosskopf et al. 2014). It belongs to the acutatum species complex, and can be differentiated effectively from other species by all genes used in Damm et al. (2012b) except for ACT; most effectively with TUB2.

112. Colletotrichum magnisporum F. Liu, L. Cai, Crous \& Damm, Persoonia, Mol. Phyl. Evol. Fungi 33: 91 (2014)

This species belongs to the gigasporum species complex and was isolated from an unknown source. Colletotrichum magnisporum is phylogenetically close to $C$. arxii and can be differentiated by all loci used in Liu et al. (2014), including ITS. Based on ITS sequence comparison, it occurs on Coffea in USA (Hawaii) and on Rhipidocladum (Poaceae) and a tropical woody plant in Panama (Vega et al. 2010, Higgins et al. 2011, Higginbotham et al. 2013).

113. Colletotrichum malvarum (A. Braun \& Casp.) SouthW., J. Mycol. 6(3): 116 (1891)

It is a pathogen on Malvaceae in Germany, Korea, the UK and belongs to the orbiculare species complex (Kim et al. 2008, Damm et al. 2013). This species is one of the slowest growing species in the orbiculare species complex (Damm et al. 2013). Colletotrichum malvarum is closely related to C. trifolii and can be separated using the GS sequence data (Damm et al. 2013).

114. Colletotrichum melonis Damm, P.F. Cannon \& Crous, Stud. Mycol. 73: 80 (2012)

This species is pathogenic to Cucumis melo in Brazil, Malus domestica in Brazil and Uruguay (Bragança et al. 2016, Velho et al. 2015) and belongs to the acutatum species complex (Damm et al. 2012b). This species can be differentiated with the use of the GAPDH, ACT and HIS3 gene sequences; most effectively with GAPDH (Damm et al. 2012b).

115. Colletotrichum menispermi Chethana, Jayawardena, Bulgakov \& K.D. Hyde, in Li et al., Fungal Diversity 78: 80 (2016)

This taxon is a saprobe on Menispermum dahuricum in Russia (Li et al. 2016). Colletotrichum menispermi belongs to the dematium species complex.

116. Colletotrichum metake Sacc., Annls mycol. 6(6): 557 (1908)

This species is known only as a pathogen on Pleioblastus simoni in Japan (Sato et al. 2012). Morphologically this species has falcate conidia, and ITS sequence data alone can be used to identify this species. It is a singleton species, closely related to C.hsienjenchang (in this study). However, further studies are needed to confirm the position of this species. Sato et al. (2012) mentioned it as a rare species. In order to fix the name of this species, it still needs to be epitypified.

117. Colletotrichum miscanthi J.A. Crouch, B.B. Clarke, J.F. White \& B.I. Hillman, Mycologia 101(5): 729 (2009)

This species has an association with the genus Miscanthus (Crouch et al. 2009a) in Japan. Tao et al. (2013) reported it as an endophyte on Bletilla ochracea in China. It belongs to the graminicola species complex (Hyde et al. 2014).

118. Colletotrichum musae (Berk. \& M. A. Curtis) Arx, Verh. K. ned. Akad. Wet., tweede sect. 51(3): 107 (1957)

Colletotrichum musae is known to be associated with fruit lesions of Musa sp. in many countries and belongs to the gloeosporioides species complex (Su et al. 2011, Sakinah et al. 2014, Sharma et al. 2015, Weir et al. 2012). It has been recognized as an endophyte on Musa acuminata in Thailand (Tao et al. 2013). ITS sequence data can be used to separate C. musae from all other species (Weir et al. 2012).

119. Colletotrichum navitas J.A. Crouch, Mycol. Res. 113(12): 1417 (2009)

This taxon belongs to the graminicola species complex and is only known as a pathogen on Panicum sp. in the USA (Crouch et al. 2009b). 
120. Colletotrichum neosansevieriae Crous \& N.A. van der Merwe, Persoonia, Mol. Phyl. Evol. Fungi 34: 221 (2015)

It is a pathogen on leaves of Sansevieria trifasciata in South Africa (Crous et al. 2015). This is a singleton species, and morphologically similar to $C$. sansevieriae. However, this species is phylogenetically distinct from $C$. sansevieriae.

121. Colletotrichum nicholsonii J.A. Crouch, B.B. Clarke, J.F. White \& B.I. Hillman, Mycologia 101(5): 730 (2009)

This taxon causes anthracnose on Paspalum sp. in Japan and New Zealand (Crouch et al. 2009a). Colletotrichum nicholsonii belongs to the graminicola species complex (Cannon et al. 2012).

122. Colletotrichum nigrum Ellis \& Halst., in Halsted, New Jersey Agric. Coll. Exp. Sta. Bull.: 297 (1895)

This species is a well-known pathogen of Capsicum sp., Cichorium intybus, Fragaria sp., Helianthus tuberosus, Lens culinaris, Lycopersicon esculentum and Solanum sp. worldwide (Liu et al. 2013a). Colletotrichum nigrum is a singleton species with a close affinity to $C$. coccodes and can be identified using ITS gene sequence (Liu et al. 2013a, Cannon et al. 2012).

123. Colletotrichum novae-zelandiae Damm, P.F. Cannon, Crous, P.R. Johnst. \& B. Weir, Stud. Mycol. 73: 25 (2012)

This species belongs to the boninense species complex (Damm et al. 2012a). Colletotrichum novaezelandiae is only known from New Zealand and has been isolated from fruit rots of Capsicum sp. and Citrus sp. (Damm et al. 2012a).

124. Colletotrichum nupharicola D.A. Johnson, Carris \& J.D. Rogers, Mycol. Res. 101(6): 647 (1997)

This species is a pathogen known only in the USA, on the aquatic plants Nuphar and Nymphae sp. (Johnson et al. 1997). Colletotrichum nupharicola belogs to the gloeosporioides species complex and is closely related to $C$. fructicola and $C$. alienum within the musae clade (Weir et al. 2012). ITS sequence can separate this from all other species.

125. Colletotrichum nymphaeae (Pass.) Aa, Netherlands Journal of Plant Pathology, Supplement 1 84(3): 110 (1978)

This taxon is a pathogen of Anemone sp. (Israel, Italy, and the Netherlands), Capsicum sp. (Indonesia and Zimbabwe), Fragariaxananassa (Bulgaria, Canada, France, Israel, Italy, Netherlands, South Africa, Spain, Switzerland, UK and the USA), Leucaena sp. (Mexico), Malus domestica (Brazil and Uruguway), Nuphar luteum (Netherlands), Nymphaea alba (Netherlands), Oenothera sp. (Netherlands), Olea europaea (Portugal), Pelargonium graveolens (India), Photinia sp. (UK), Protea sp. (Australia and South Africa), Phaseolus sp. (Netherlands) and Vitis vinifera (China) (Damm et al. 2012b, Velho et al. 2014, 2015, Baroncelli et al. 2015b, Talhinhas et al. 2015, Liu et al. 2016). It has also been recorded as a saprobe from litter in Thailand (Damm et al. 2012b). Colletotrichum nymphaeae belongs to the acutatum species complex and can be separated from other species by analysis of TUB2 sequence data (Damm et al. 2012b).

126. Colletotrichum ochraceae G. Tao, Zuo Y. Liu \& L. Cai [as 'ochracea'], in Tao, Liu, Liu, Gao \& Cai, Fungal Diversity 61: 156 (2013)

This taxon is an endophyte of Bletilla ochracea in China (Tao et al. 2013). It belongs to the cadatum species complex. Colletotrichum ochraceae can be identified from the other species of this complex as it lacks conidial appendages.

127. Colletotrichum ocimi Damm, in Damm, O'Connell, Groenewald \& Crous, Stud. Mycol. 79: 70 (2014)

This species causes anthracnose on leaves and stems of Ocimum basilicum in Italy (Damm et al. 2014). Colletotrichum ocimi belongs to the destructivum complex. It forms conidiogenous cells that are often covered by a mucoid sheath and can be identified by its unique ITS, CHS-1, HIS3, ACT and TUB2 sequences (Damm et al. 2014).

128. Colletotrichum oncidii Damm, P.F. Cannon \& Crous, Stud. Mycol. 73: 26 (2012) 
Colletotrichum oncidii has been recorded as an endophyte in leaves of Oncidium sp. in Germany and belongs to the boninense species complex (Damm et al. 2012a). It forms a sister group to $C$. cymbidiicola.

129. Colletotrichum orbiculare Damm, P.F. Cannon \& Crous, in Damm, Cannon, Liu, Barreto, Guatimosim \& Crous, Fungal Diversity 61: 39 (2013)

This taxon is a pathogen of Benincasa hispida (Cucurbitaceae) in Australia, Cucumis melo in Japan, Cucumis sativus in Japan, the UK, and the Netherland. Colletotrichum orbiculare belongs to the orbiculare species complex and is closely related to $C$. sidae, $C$. spinosum and $C$. tebeestii (Damm et al. 2013). This species can be separated from other species with its unique GS, ACT and HIS3 sequence data (Damm et al. 2013).

130. Colletotrichum orchidophilum Damm, P.F. Cannon \& Crous, in Damm, Cannon, Woudenberg, \& Crous, Stud. Mycol. 73: 83 (2012)

It is pathogenic or endophytic to Orchidaceae (Ascocenda sp., Cycnoches aureum, Dendrobium sp. and Phalaenopsis sp.) (Damm et al. 2012). It clusters basal to the acutatum species complex, and is a singleton species. Colletotrichum orchidophilum can be distinguished by its very narrow cylindrical conidia and uniformly shaped, dark brown, pyriform to spathulate appressoria (Damm et al. 2012b).

131. Colletotrichum panacicola Uyeda \& S. Takim., in Takimoto, Chosen Nokai-ho 14: 24 (1919) This species causes anthracnose on Panax sp. in China, Japan, Korea and Russia (Damm et al. 2014). Colletotrichum panacicola belongs to the destructivum species complex and has pyriform, olive appressoria (Damm et al. 2014). It can be identified by ITS and GAPDH sequences (Damm et al. 2014).

132. Colletotrichum paranaense C.A.D. Bragança \& Damm, Fungal Biology 120: 555 (2016)

This species is a pathogen of Caryocar brasiliense, Malus domestica and Prunus persica in Brazil (Bragança et al. 2016). It belongs to the acutatum species complex and can be identified by its unique TUB2 and HIS3 sequence data.

133. Colletotrichum parsonsiae Damm, P.F. Cannon, Crous, P.R. Johnst. \& B. Weir, in Damm,

Cannon, Woudenberg, Johnston, Weir, Tan, Shivas \& P.Crous, Stud. Mycol. 73: 27 (2012)

This taxon is an endophyte of Bletilla ochracea in China (Tao et al. 2013) and Parsonia caspularis in New Zealand (Damm et al. 2012a). It belongs to the boninense species complex (Damm et al. 2012a).

134. Colletotrichum paspali J.A. Crouch, B.B. Clarke, J.F. White \& B.I. Hillman, Mycologia 101(5): 730 (2009)

It causes anthracnose on Paspalum notatum in Japan (Crouch et al. 2009a). This species belongs to the graminicola species complex (Cannon et al. 2012).

135. Colletotrichum paxtonii Damm, P.F. Cannon \& Crous, in Damm, Cannon, Woudenberg, \& Crous, Stud. Mycol. 73: 85 (2012)

This species is known from Musa sp. as a pathogen in Saint Lucia, belongs to the acutatum species complex, and can be separated from other species with the analysis of GAPDH or TUB2 sequence data; most effectively with TUB2 (Damm et al. 2012b).

136. Colletotrichum petchii Damm, P.F. Cannon \& Crous, in Damm, Cannon, Woudenberg, Johnston, Weir, Tan, Shivas \& P.Crous, Stud. Mycol. 73: 29 (2012)

This species is recorded as a pathogen from Dracaena sp. in China, Italy and the Netherlands. Colletotrichum petchii is a member of the boninense species complex (Damm et al. 2012b).

137. Colletotrichum phormii (Henn.) D.F. Farr \& Rossman, in Farr, Aime, Rossman \& Palm, Mycol. Res. 110(12): 1403 (2006)

This taxon has been reported as a pathogen from Phormium sp. in Germany, New Zealand, South Africa and the UK (Damm et al. 2012b). It belongs to the acutatum species complex and is closely related to $C$. salicis. It can be seperated from other species by TUB2, GAPDH, HIS3 and ACT sequences; most effectively with HIS3 (Damm et al. 2012b).

138. Colletotrichum phyllanthi (H.S. Pai) Damm, P.F. Cannon \& Crous, in Damm, Cannon, Woudenberg, Johnston, Weir, Tan, Shivas \& P.Crous, Stud. Mycol. 73: 31 (2012) 
It is a pathogen and an endophyte of Phyllanthus acidus in India and belongs to the boninense species complex (Damm et al. 2012b).

139. Colletotrichum pisicola Damm, in Damm, O'Connell, Groenewald \& Crous, Stud. Mycol. 79: $71(2014)$

This species is a pathogen only of Pisum sp. in the USA. Colletotrichum pisicola is characterized by distinctly curved conidia with few, short, pale brown setae with rounded tips. It is the basal species of the destructivum species complex (Damm et al. 2014). The sequenes of all loci studied in Damm et al. (2014) are unique for this species.

140. Colletotrichum proteae F. Liu, Damm, L. Cai \& Crous, Fungal Diversity 61: 100 (2013)

It is a pathogen only on Protea sp. in South Africa. Even though, the conidia of C. proteae resemble the acutatum species complex, phylogenetically this species clusteres in the gloeosporioides species complex with a close affinity to C. gloeosporioides (Liu et al. 2013b, Cannon et al. 2012).

141. Colletotrichum pseudoacutatum Damm, P.F Cannon \& Crous, in Damm, Cannon, Woudenberg, \& Crous, Stud. Mycol. 73: 91 (2012)

This taxon is only known from Pinus radiata in Chile. It is basal to the acutatum species complex and considered as a singleton species (Cannon et al. 2012, Hyde et al. 2014).

142. Colletotrichum pseudomajus F. Liu, L. Cai, Crous \& Damm, Persoonia, Mol. Phyl. Evol. Fungi 33: 91 (2014)

Colletotrichum pseudomajus is an endophyte only known on Camellia sinensis in Taiwan and belongs to the gigasporum species complex (Liu et al. 2014).

143. Colletotrichum psidii Curzi, Atti Ist. bot. R. Univ. Pavia, 3 Sér. 3(3): 207 (1927)

Only one isolate is available for this species that is known as a pathogen of Psidium in Italy, but it is well separated from all other species by its by ITS sequence (Weir et al. 2012). Colletotrichum psidii belongs to the kahawae clade within gloeosporioides species complex (Weir et al. 2012).

144. Colletotrichum pyricola Damm, P.F. Cannon \& Crous, in Damm, Cannon, Woudenberg, \& Crous, Stud. Mycol. 73: 94 (2012)

This species is known only from New Zealand causing fruit rot of Pyrus communis (Damm et al. 2012b). It belongs to the acutatum species complex and can be identified with its unique ACT, TUB2, CHS-1, GAPDH and HIS3 sequences (Damm et al. 2012b).

145. Colletotrichum queenslandicum B. Weir \& P.R. Johnst., in Weir, Johnston \& Damm, Stud. Mycol. 73: 164 (2012)

This is a pathogen, known from Capsicum sp., Carica papaya and Persea americana in Australia, from Coffea sp. in Fiji and Olea europaea in Montenegro (Weir et al. 2012, Schena et al. 2014, De Silva et al. 2016). Colletotrichum queenslandicum belongs to the musae clade within the gloeosporioides species complex. It can be best distinguished with the use of TUB2, GAPDH and GS sequences (Weir et al. 2012).

146. Colletotrichum quinquefoliae Jayawardena, Bulgakov \& K.D. Hyde, in $\mathrm{Li}$ et al. Fungal Diversity 78: 83 (2016)

This taxon is a saprobe and a weak pathogen on Parthenocissus quinquefolia in Russia. It belongs to the dematium species complex (Li et al. 2016).

147. Colletotrichum radicis F. Liu, L. Cai, Crous \& Damm, Persoonia, Mol. Phyl. Evol. Fungi 33: 93 (2014)

Colletotrichum radicis belongs to the gigasporum species complex. Colletotrichum radicis has been isolated from a root of an undetermined host in Costa Rica (Liu et al. 2014).

148. Colletotrichum rhexiae Ellis \& Everh., Proc. Acad. nat. Sci. Philad. 46: 372 (1894)

This species is a pathogen of Rhexia sp. in the USA as well as a fruit endophyte on Vaccinium macrocarpon in the USA (Doyle et al. 2013). Colletotrichum rhexiae belongs to the kahawae clade within the gloeosporioides species complex (Hyde et al. 2014).

149. Colletotrichum rhombiforme Damm, P.F. Cannon \& Crous, in Damm, Cannon, Woudenberg, \& Crous, Stud. Mycol. 73: 95 (2012) 
Colletotrichum rhombiforme is a pathogen of Olea europaea (Portugal) and Vaccinium macrocarpum (USA) and belongs to the acutatum species complex (Damm et al. 2012b). It can be distinguished by its rhomboidal ascospores. This species can be separated from other species by all the sequences studied in Damm et al. (2012b) except CHS-1; best identified with TUB2 and ITS sequence data.

150. Colletotrichum riograndense D.M. Macedo, R.W. Barreto, O.L. Pereira \& B.S. Weir, in Macedo, Pereira, Hora Jr., Weir \& Barreto Autralasian Plant Pathology 45: 49 (2016)

This taxon is a pathogen on Tradescantia viz. fluminensis in Brazil and a member of the spaethianum species complex. Colletotrichum riograndense is closely related to C. bletillum and $C$. incanum (Macedo et al. 2016).

151. Colletotrichum rusci Damm, P.F. Cannon \& Crous, in Damm, Woudenberg, Cannon \& Crous, Fungal Diversity 39: 72 (2009)

This species is a pathogen of Ruscus sp. in Italy (Damm et al. 2009). It is a singleton species and phylogenetically close to $C$. trichellum (Cannon et al. 2012).

152. Colletotrichum salicis (Fuckel) Damm, P.F. Cannon \& Crous, in Damm, Cannon, Woudenberg, \& Crous, Stud. Mycol. 73: 97 (2012)

This species is a pathogen on Acer platanoides (USA), Fragaria $\times$ ananassa (New Zealand), Malus domestica (Germany, New Zealand), Populus sp. (Netherlands, New Zealand), Pyrus pyrifolia (New Zealand), Salix sp. (Germany, Netherlands, New Zealand and UK) and Solanum lycopersicum (Germany) (Damm et al. 2012b). It belongs to the acutatum species complex and can be distinguished with HIS3, TUB2, GAPDH and ACT (Damm et al. 2012b). Sexual morph of this species has been identified as Glomerella salicis (Damm et al. 2012b).

153. Colletotrichum salsolae B. Weir \& P.R. Johnst., in Weir, Johnston \& Damm, Stud. Mycol. 73: 164 (2012)

It is known to be pathogenic on Salsola sp. in Hungary (Schwarczinger et al. 1998). Colletotrichum salsolae belongs to the musae clade within the gloeosporioides species complex and can be distinguished using TUB2 and GAPDH (Weir et al. 2012).

154. Colletotrichum sansevieriae Miho Nakam. \& Ohzono, in Nakamura, Ohzono, Iwai \& Arai, J. Gen. Pl. Path. 72(4): 253 (2006)

It is known only on Sansevieria sp. in Australia, Japan, Korea and the USA (Nakamura et al. 2006, Aldaoud et al. 2011, Palmateer et al. 2012, Park et al. 2013, Liu et al. 2014). It is a singleton species closely related to C. ledebouriae (Crous et al. 2013b)

155. Colletotrichm scovillei Damm, P.F. Cannon \& Crous, in Damm, Cannon, Woudenberg, \& Crous, Stud. Mycol. 73: 100 (2012)

It causes diseases of Capsicum sp. (Brazil, China, Indonesia, Taiwan and Thailand), and belongs to the acutatum species complex (Damm et al. 2012b, Caires et al. 2014, Baroncelli et al. 2015b, Hao et al. 2016). Use of TUB2, GAPDH and ACT sequence data can distinguish $C$. scovillei from other species of the acutatum species complex; with GAPDH being most effective.

156. Colletotrichum sedi Jayawardena, Bulgakov \& K.D. Hyde, in Liu et al., Fungal Diversity $72: 27$ (2015)

This species is a saprobe on Sedum sp. in Russia and belongs to the dematium species complex (Liu et al. 2015b). Colletotrichum sedi is a sister taxon to $C$. circinans and $C$. spinaciae and produces appressoria in small groups or short chains and smaller conidia.

157. Colletotrichum siamense Phoulivong, L. Cai \& K.D. Hyde, in Prihastuti, Cai, Chen, McKenzie \& Hyde, Fungal Diversity 39: 98 (2009)

Colletotrichum siamense was considered to be a species complex, in which the cryptic species can be resolved using the ApMat marker (Sharma et al. 2015). However, Liu et al. (2016) showed using the Genealogical Concordance Phylogenetic Species Recognition (GCPSR) that it is not a species complex and the earlier described species $C$. communis, $C$. dianesei, $C$. endomangiferae, $C$. hymenocallidis, $C$. jasmini-sambac, $C$. melanocaulon and $C$. murrayae were synonymised with $C$. siamense. It occurs as a pathogen on a wide range of hosts and has a worldwide occurence including Capsicum sp., Olea europaea, Persea americana, Pistacia vera in Australia (Weir et al. 
2012, Schena et al. 2014, De Silva et al. 2016), Mangifera indica in Brazil and Colombia (Lima et al. 2013, Sharma et al. 2015, Hoz et al. 2016), Camellia sinensis, Citrus sp., Hymenocallis sp., Jasminum sambac and Murraya sp. in China (Yang et al. 2009, Wikee et al. 2011, Peng et al. 2012, Wang et al. 2016), Bauhinia variegata, Cassia fisculata, Citrus sp., Cocos nucifera, Ficus elastic, Mangifera indica, Psidium guajava and Saraca indica in India (Lima et al. 2013, Liu et al. 2015a, Sharma et al. 2015), Citrus, Murraya sp. and on Strawberry in Italy (Peng et al. 2012), Dioscorea rotunda, Commelina sp. from Nigeria, Carica papaya from South Africa, Coffea Arabica, Capsicum annuum, Pennisetum purpureum, and Cymbopogon citrates in Thailand (Manamgoda et al. 2013), Fragaria $\times$ ananassa, Malus domestica Vaccinium macrocarpon, Vitis vinifera from the USA (Weir et al. 2012, Doyle et al. 2013) and Jasminium sambac in Vietnam (Prihastuti et al. 2009, Wikee et al. 2011). Colletotrichum siamense can be identified with the use of CAL or TUB sequence data (Weir et al. 2012).

158. Colletotrichum sidae Damm \& P.F. Cannon, in Damm, Cannon, Liu, Barreto, Guatimosim \& Crous, Fungal Diversity 61: 44 (2013)

This species is a pathogen on Sida spinosa (Prickly sida) in the USA and belongs to the orbiculare species complex (Damm et al. 2013). It can be distinguished with GS and ITS sequences.

159. Colletotrichum simmondsii R.G. Shivas \& Y.P. Tan, Fungal Diversity 39:119 (2009)

It is a pathogen on Capsicum sp., Carica papaya (Australia), Cyclamen sp. (Netherlands), Fragaria $\times$ ananassa (Australia), Mangifera indica (Australia), Murrayae sp. (China) and Protea cynaroides (USA) (Damm et al. 2012b, Peng et al. 2012, De Silva et al. 2016). Colletotrichum simmondsii is also a stem endophye of Actinidia chinensis in Australia (Shivas \& Tan 2009). This species belongs to the acutatum species complex and can be distinguished with the analysis of GAPDH and TUB2 sequence data; with effectively by TUB2 gene (Damm et al. 2012b).

160. Colletotrichum sloanei Damm, P.F. Cannon \& Crous, in Damm, Cannon, Woudenberg, \& Crous, Stud. Mycol. 73: 103 (2012)

It is known as an endophyte of Theobroma cacao in Malaysia. This species belongs to the acutatum species complex and can be distinguished with the use of TUB2, ACT and HIS3 sequence data (Damm et al. 2012b).

161. Colletotrichum somersetense J.A. Crouch, IMA Fungus 5(1):27 (2014)

This species is a pathogen on leaves of Sorghastrum nutans in the USA (Crouch 2014). Colletotrichum somersetense belongs to the caudatum species complex. It can be identified using any of the gene regions (Apn2, ITS, Sod2, Mat/Apn2) used in Crouch (2014).

162. Colletotrichum spaethianum (Allesch.) Damm, P.F. Cannon \& Crous, in Damm, Woudenberg, Cannon \& Crous, Fungal Diversity 39: 74 (2009)

Colletotrichum spaethianum has been recorded as a saprobe on dead stems of Hosta sieboldiana in Germany, Hymenocallis americana and Peucedanum praeruptorum in China (Damm et al. 2009, Yang et al. 2009, Guo et al. 2013) and as a pathogen of Allium fistulosum in Brazil, Hermerocallis sp. in Brazil and New Zealand and Lillium sp. in Korea (Damm et al. 2009, Vieira et al. 2014b, Cheon \& Jeon 2016, Santana et al. 2016). It belongs to the spaethianum species complex (Cannon et al. 2012) and can be distinguished by its setae that have usually acute tips and cylindrical to conical bases and by its appressoria that are are irregular in outline and more or less lobed (Damm et al. 2009).

163. Colletotrichum spinaciae Ellis \& Halst., J. Mycol. 6(1): 34 (1890)

This taxon is a pathogen on Spinacea sp. in Germany, Italy, the Netherlands and Turkey (Damm et al. 2009, Yang et al. 2009, Kurt et al. 2016), Chenopodium album in the USA, Portulaca oleracea in Canada and Medicago sativa in the Netherlands (Damm et al. 2009). On hosts other than spinach it develops only weak symptoms (von Arx 1957). It belongs to the dematium species complex (Cannon et al. 2012).

164. Colletotrichum spinosum Damm \& P.F. Cannon, in Damm, Cannon, Liu, Barreto, Guatimosim \& Crous, Fungal Diversity 61: 46 (2013) 
This species causes seed blight and stem anthracnose of Xanthium spinosum in Argentina and Australia (Damm et al. 2013). It belongs to the orbiculare species complex and can be identified effectively based on GAPDH, HIS3, TUB2 and GS sequences data.

165. Colletotrichum sublineola Henn. ex Sacc. \& Trotter, Syll. fung. (Abellini) 22: 1206 (1913)

It is known only as a pathogen of Sorghum sp. in Togo and the USA (Crouch \& Tomaso-Peterson 2012). Colletotrichum sublineola is a member of the graminicola species complex (Cannon et al. 2012). It can be distinguished by Apn2, Apn2/Mat1 and SOD2 sequence data (Crouch \& TomasoPeterson 2012).

166. Colletotrichum syzygiicola Udayanga, Manamgoda \& K.D. Hyde [as 'syzygicola'], in Udayanga, Manamgoda, Liu, Chukeatirote \& Hyde, Fungal Diversity 61: 173 (2013)

This species belongs to the gloeosporioides species complex and causes anthracnose of Citrus aurantifolia and Syzygium samarangense in Thailand (Udayanga et al. 2013).

167. Colletotrichum tabacum Böning, Prakt. Bl. Pflanzenbau Pflanzenschutz 10: 89 (1932)

This taxon causes anthracnose of Nicotiana sp. in France, India, Germany, and Zimbabwe as well as on Centella asiatica in Madagascar (Damm et al. 2014). It belongs to the destructivum species complex and can be distinguish by its appressoria with a distinct penetration pore with a dark halo (Damm et al. 2014). Colletotrichum tabacum is distingushed from the other species in the destructivum complex by all the loci studied by Damm et al. (2014).

168. Colletotrichum tamarilloi Damm, P.F. Cannon \& Crous, in Damm, Cannon, Woudenberg, \& Crous, Stud. Mycol. 73: 105 (2012)

Colletotrichum tamarilloi belongs to the acutatum species complex and occurs as a pathogen on Solanum betaceum in Colombia (Damm et al. 2012a, Hoz et al. 2016). This species can be separated from other species using CHS-1, HIS3, TUB2 and GAPDH sequences; most effectively by GAPDH sequence data (Damm et al. 2012a).

169. Colletotrichum tanaceti M. Barimani, S.J. Pethybridge, N. Vaghefi, F.S. Hay \& P.W.J. Taylor, Pl. Path. 62(6): 1248-1257 (2013)

It is a pathogen, only known from Tanacetum cinerariifolium in Australia and Tasmania (Barimani et al. 2013, Damm et al. 2014). Colletotrichum tanaceti belongs to the destructivum species complex (Damm et al. 2014).

170. Colletotrichum tebeesti Damm \& P.F. Cannon, in Damm, Cannon, Liu, Barreto, Guatimosim \& Crous, Fungal Diversity 61: 48 (2013)

This taxon belongs to the orbiculare species complex and is known as a pathogen on Malva pusilla in Canada (Damm et al. 2014). Colletotrichum tebeestii can be differentiated from the other species in the orbiculare species complex by using GAPDH sequence data.

171. Colletotrichum temperatum V. Doyle, P.V. Oudem. \& S.A. Rehner, PLoS ONE 7(12): e51392, 17 (2012)

This species is a pathogen on Vaccinium macrocarpon as well as a stem endophyte on $V$. macrocarpon in the USA. Colletotrichum temperatum belongs to the gloeosporioides species complex (Doyle et al. 2013).

172. Colletotrichum theobromicola Delacr., Bull. Soc. mycol. Fr. 21: 191 (1905)

Colletotrichum theobromicola is broadly distributed as a pathogen in tropical and subtropical regions on a wide range of hosts including Acca sp., Annona sp., Limonium sp., Mangifera indica, Olea sp., Stylosanthes sp., Theobroma cacao, Quercus sp. (Weir et al. 2012, Schena et al. 2014, Sharma et al. 2015, Hoz et al. 2016). Colletotrichum theobromicola is also known as a pathogen of strawberry runners; previously known as $C$. fragaria, which has been synonimized with $C$. theobromicola by Weir et al. (2012). It belongs to the gloeosporioides species complex and ITS sequence can be used to distinguish this species from all other taxa.

173. Colletotrichum ti B. Weir \& P.R. Johnst., in Weir, Johnston \& Damm, Stud. Mycol. 73: 171 (2012)

This species is a leaf pathogen of Cordyline sp. in New Zealand. Colletotrichum ti belongs to the kahawae clade within the gloeosporioides species complex (Weir et al 2012). TUB2 and GAPDH sequences can be used to distinguish this taxon (Weir et al 2012). 
174. Colletotrichum tofieldiae (Pat.) Damm, P.F. Cannon \& Crous, in Damm, Woudenberg, Cannon \& Crous, Fungal Diversity 39: 77 (2009)

This taxon occurs on many host plants including Agapanthus sp. in Portugal, Dianthus sp. in the UK, Lupinus sp. and Semele gayae in Germany, and Tofieldia sp. in Switzerland and in China (Damm et al. 2009, Hacquard et al. 2016). This species has also been collected as a leaf endophyte of Bletilla ochracea in China (Tao et al. 2013) and as a beneficial root endophyte of Arabidopsis thaliana in Spain (Hacquard et al. 2016). Colletotrichum tofieldiae belongs to the spaethianum species complex (Cannon et al. 2012).

175. Colletotrichum torulosum Damm, P.F. Cannon, Crous, P.R. Johnst. \& B. Weir, in Damm, Cannon, Woudenberg, Johnston, Weir, Tan, Shivas \& P.Crous, Stud. Mycol. 73: 32 (2012)

This taxon is an endophyte of Solanum melongena and a pathogen of Passiflora edulis in New Zealand and is characterized by highly convoluted appressoria (Damm et al. 2012a). Colletotrichum torulosum belongs to the boninense species complex (Damm et al. 2012a).

176. Colletotrichum trichellum (Fr.) Duke, Trans. Br. mycol. Soc. 13(3-4): 173 (1928)

This species occurs as a pathogen on Hedera sp. worldwide (Damm et al. 2009, Hyde et al. 2009). It is a singleton species with close affinity to C. rusci (Cannon et al. 2012).

177. Colletotrichum trifolii Bain, in Bain \& Essary, J. Mycol. 12(5): 193 (1906)

This species is a pathogen on Medicago sativa and Trifolium pratense in the USA and on Malva sylvestris in China (Damm et al. 2014, Samac et al. 2014, Zhou et al. 2014). Colletotrichum trifolii belongs to the orbiculare species complex and has darker and often knobby setae than the other species in this complex (Damm et al. 2014). It is closely related to C. malvarum and can be distinguished with GS sequences.

178. Colletotrichum tropicale E.I. Rojas, S.A. Rehner \& Samuels, Mycologia 102(6): 1331 (2010) It has been recorded from hosts in tropical America including Annona muricata (Annonaceae), Cordia aliobora (Boraginaceae), Trichilia tuberculata (Meliaceae), Viola surinamensis (Myristicaceae), and as leaf endophyte of Theobroma cacao (Malvaceae) (Rojas et al. 2010), Litchi chinensis (Sapindaceae) in Japan (Weir et al. 2012) and Pennisetum purpureum in Thailand (Manamgoda et al. 2013). Colletotrichum tropicale belongs to the gloeosporioides species complex and can be distinguished using TUB2, CHS-1, GS or SOD2 sequences (Weir et al. 2012).

179. Colletotrichum tropicicola Phouliv., Noireung, L. Cai \& K.D. Hyde, Cryptog. Mycol. 33(3): 353 (2012)

This species is an endophyte of Citrus maxima and Paphiopedilum bellatulum in Thailand (Noireung et al. 2012). It is a singleton species with close affinity to $C$. excelsum-altitudinum.

180. Colletotrichum truncatum (Schwein.) Andrus \& W.D. Moore, Phytopathology 25: 121 (1935) This taxon has a wide host range including the families Amaranthaceae, Amaryllidaceae, Apocynaceae, Asteraceae, Basellaceae, Brassicaceae, Cactaceae, Caricaceae, Convolvulaceae, Cyperaceae, Euphorbiaceae, Fabaceae, Malvaceae, Nyctaginaceae, Oleaceae, Pipieraceae, Plumbaginaceae, Poaceae, Polygonaceae, Rosaceae, Solanaceae and Theaceae (Damm et al. 2009, De Silva et al. 2016, He et al. 2016, Wang et al. 2016). It belongs to the truncatum species complex (Cannon et al. 2012). Colletotrichum truncatum is associated with symptoms of leaf tip die-back, foliar blight and leaf spots (Shenoy et al. 2007). The taxon is also known to be pathogenic to humans (Damm et al. 2009, Squissato et al. 2015). Colletotrichum aciculare which was introduced in Ariyawansa et al. 2015 is also synonymized under this species, due to the high morphological and phylogenetic similarities (This study).

181. Colletotrichum utrechtense Damm, in Damm, O'Connell, Groenewald \& Crous, Stud. Mycol.

79: 77 (2014)

This species is a pathogen on Trifolium pratense in the Netherlands and belongs to the destructivum species complex (Damm et al. 2014). Colletotrichum utrechtense can be distinguished by CHS-1, HIS3 and TUB2 sequence data (Damm et al. 2014).

182. Colletotrichum verruculosum Damm, P.F. Cannon \& Crous, in Damm, Woudenberg, Cannon \& Crous, Fungal Diversity 39: 81 (2009) 
This species is known on Crotalaria juncea from Zimbabwe (Damm et al. 2009). Colletotrichum verruculosum belongs to the spaethianum species complex (Cannon et al. 2012).

183. Colletotrichum vietnamense F. Liu, L. Cai, Crous \& Damm, Persoonia, Mol. Phyl. Evol. Fungi 33: 93 (2014)

This species is a pathogen on Coffea sp. in Vietnam and belongs to the gigasporum species complex (Liu et al. 2014).

184. Colletotrichum vignae Damm, in Damm, O'Connell, Groenewald \& Crous, Stud. Mycol. 79: 78 (2014)

Colletotrichum vignae is known from Vigna unguiculata in Nigeria causing anthracnose and belongs to the destructivum species complex (Damm et al. 2014). It is one of the slowest growing species in the destructivum species complex and can be identified by its ITS, GAPDH, HIS3 and ACT sequences (Damm et al. 2014).

185. Colletotrichum viniferum L.J. Peng, L. Cai, K.D. Hyde \& Z-Y. Ying, Mycoscience 54(1): 36 (2013)

It has been identified as a pathogen on Vitis vinifera in China (Peng et al. 2013, Yan et al. 2015). Colletotrichum viniferum belongs to the gloeosporioides species complex (Peng et al. 2013).

186. Colletotrichum walleri Damm, P.F. Cannon \& Crous, in Damm, Cannon, Woudenberg, \& Crous, Stud. Mycol. 73: 106 (2012)

This species is an endophyte of Coffea arabica in Vietnam and belongs to the acutatum species complex (Damm et al. 2012b). It is easily distinguished by using HIS3 and ITS sequence data.

187. Colletotrichum wuxiense Y.C. Wang, X.C. Wang \& Y.J. Yang, Scientific Reports 6 (no:35287): 8 (2016)

It is a pathogen on leaves of Camellia sinensis in China. This species belongs in the gloeosporioides species complex (Wang et al. 2016). Colletotrichum wuxiense can be distinguished from the other members of the complex by its concatenated ApMat and GS sequence data.

188. Colletotrichum xanthorrhoeae R.G. Shivas, Bathgate \& Podger, Mycol. Res. 102 (3): 280 (1998)

This species is a pathogen on Xanthorrhoae preissii causing leaf spot in Australia (Shivas et al. 1998). Colletotrichum xanthorrhoeae belongs to gloeosporioides species complex and ITS sequence can be used to identify this species (Weir et al. 2012).

189. Colletotrichum yunnanense Xiao Ying Liu \& W.P. Wu, in Liu, Xie \& Duan, Mycotaxon 100: 139 (2007)

This species is a leaf endophyte on Buxus sp. in China (Liu et al. 2007, Xia-Ying et al. 2007). Colletotrichum yunnanense is a singleton species and closely related to $C$. dracaenophilum (Cannon et al. 2012, Hyde et al. 2014).

190. Colletotrichum zoysiaeJ.A. Crouch, IMA Fungus 5(1):27 (2014)

This taxon belongs to the caudatum species complex and has been recorded as a pathogen on Zoysia tenuifolia only in Japan (Crouch 2014). It can be identified using any of the gene regions (Apn2, ITS, Sod2, Mat/Apn2) used in Crouch (2014).

\section{Doubtful species}

Colletotrichum phaseolorum S. Takim., Ann. phytopath. Soc. Japan 5: 21 (1934)

This taxon is a pathogen af Phaseolus radiatus var. aureus and on Vigna sinensis in Japan (Damm et al. 2009). Colletotrichum phaseolorum is a singleton species, phylogenetically close to $C$. chlorophyti (Damm et al. 2009, Hyde et al. 2014). However, as it has two ex-type strains belonging to two different species, we condiser this species as a doubtful species.

\section{Excluded species}

Colletotrichum corchori-capsularis X.P. Niu, H. Gao, J.M. Qi, M.C. Chen \& J.G. Su [as 'corchorum-capsularis'], Scientific Reports 6 (no. 25179): 4 (2016) 
Colletotrichum corchorum-capsularis belongs to the truncatum species complex. This is a pathogen on Corchorus capsularis in China (Niu et al. 2016). However, as the authors have not listed an authentic dried type specimen, this species cannot be accepted as an authentic species.

\section{Acknowledgements}

We are grateful to the CARS-30, Youth Foundation of Beijing Academy of Agriculture and Forestry Sciences (number QNJJ 201515) and Mushroom Research Foundation, Chiang Rai, Thailand. K.D. Hyde thanks the Chinese Academy of Sciences, project number 2013T2S0030, for the award of Visiting Professorship for Senior International Scientists at Kunming Institute of Botany. Ruvishika S. Jayawardena thanks B. Weir for his valuable suggestions to improve this manuscript. Fang Liu is thanked for providing the photos. The authors have no conflict of interest to declare.

\section{References}

Afanador-Kafuri L, Minz D, Maymon M, Freeman S. 2003 - Characterization of Colletotrichum isolates from tamarillo, passiflora, and mango in Colombia and identification of a unique species from the genus. Phytopathology 93, 579-587.

Afanador-Kafuri L, González A, Gañán L, Mejía JF, Cardona N, Alvarez E. 2014 Characterization of the Colletotrichum species causing anthracnose in Andean blackberry in Colombia. Plant Disease 98, 1503-1513.

Aldaoud R, de Alwis S, Salib S, Cunnington JH, Doughty S. 2011 - First record of Colletotrichum sansevieriae on Sansevieria sp. (mother-in-law's tongue) in Australia. Australasian Plant Disease Notes 6, 60-61.

Álvarez E, Gañán L, Rojas-Triviño A, Mejía JF, Llano GA, González A. 2014 - Diversity and pathogenicity of Colletotrichum species isolated from soursop in Colombia. European journal of plant pathology 139, 325-338.

Ariyawansa HA, Hawksworth DL, Hyde KD, Jones EBG, Maharachchikumbura SSN, Manamgoda DS, Thambugala KM, Udayanga D, Camporesi E, Daranagama A, Jayawardena R, Liu JK, McKenzie EHC, Phookamsak R, Senanayake IC, Shivas RG, Xu J-C. 2014 Epitypification and neotypification: guidelines with appropriate and inappropriate examples. Fungal Diversity 69, 57-91.

Ariyawansa HA, Hyde KD, Jayasiri SC, Buyck B, Thilini Chethana KW, Dai D-Q, Dai YC, Daranagama DA, Jayawardena RS, Lucking R, Ghobad-Nejhad M, Niskanen T, Thambugala KM, Voigt K, Zhao RL, Li G-J, Doilom M, Boonmee S, Yang ZL, Cai Q, Cui Y-Y, Bahkali AH, Chen J, Cui BK, Chen JJ, Dayarathne MC, Dissanayake AJ, Ekanayaka AH, Hashimoto A, Hongsanan S, Jones EBG, Larsson E, Li WJ, Li Q-R, Liu JK. 2015 Fungal diversity notes 111-252 - taxonomic and phylogenetic contributions to fungal taxa. Fungal Diversity 75, 27-274.

Armstrong-Cho CL, Banniza S. 2006 - Glomerella truncata sp. nov., the teleomorph of Colletotrichum truncatum. Mycological Research 110, 951-956.

Arx JA von. 1957 - Die Arten der Gattung Colletotrichum Cda. Phytopathologische Zeitschrift 29, 413-468.

Barimani M, Pethybridge SJ, Vaghefi N, Hay FS, Taylor PWJ. 2013 - A new anthracnose disease of pyrethrum caused by Colletotrichum tanaceti sp. nov. Plant Pathology 62, 1248-1257.

Baroncelli R, Sreemviasaprasad S, Lane CR, Thon MR, Sukno SA. 2014 - First report of Colletotrichum acutatum sensu lato (Colletotrichun godetiae) causing anthracnose in grapevine (Vitis vinifera) in the United Kingdom. New Disease Report 29, 26.

Baroncelli R, Sarrocco S, Zapparata A, Tavarini S, Angelini LG, Vannacci G. 2015a Characterization and epidemiology of Colletotrichum acutatum sensu lato $(C$. chrysanthemi) causing Carthamus tinctorius anthracnose. Plant Pathology 64, 375-384. 
Baroncelli R, Zapparata A, Sarrocco S, Sukno SA, Lane CR, Thon MR, Vannacci G, Holub E, Sreenivasaprasad S. 2015b - Molecular diversity of anthracnose pathogen populations associated with UK strawberry production suggests multiple introductions of three different Colletotrichum species. PloS One 10, e0129140.

Bezerra JP, Ferreira PV, Barbosa L da F, Ramos-Sobrinho R, Pinho DB, Reis A, Assuncao IP, Lima GSA. 2016 - First report of anthracnose on chayote fruits (Sechium edule) caused by Colletotrichum brevisporum. Plant Disease 100, 217.

Beirn LA, Clarke BB, Crouch JA. 2014 - Influence of host and geographic locale on the distribution of Colletotrichum cereale lineages. PloS One 9, e97706.

Bragança CA, Damm U, Baroncelli R, Júnior NSM, Crous PW. 2016 - Species of the Colletotrichum acutatum complex associated with anthracnose diseases of fruit in Brazil. Fungal Biology 120, 547-561.

Cai L, Hyde KD, Taylor PWJ, Weir B, Waller JM, Abang MM, Zang JC, Yang YL, Phouliyong S, Prihastuti ZY, Shivas RG, McKenzie EHC, Johnston PR. 2009 - A polyphasic approach for studying Colletotrichum. Fungal Diversity 39, 183-204.

Caires NP, Pinho DB, Souza JSC, Silva MA, Lisboa DO, Pereira OL, Furtado GQ. 2014 - First report of anthracnose on pepper fruit caused by Colletotrichum scovillei in Brazil. Plant Disease 98, 1437.

Cannon PF, Damm U, Johnston PR, Weir BS. 2012 - Colletotrichum current status and future directions. Studies in Mycology 73, 181-213.

Cheon W, Jeon Y. 2016 - First report of anthracnose caused by Colletotrichum spaethianum on fragrant plantain lily in Korea. Plant Disease 100, 224.

Chowdappa P, Chethana CS, Pant RP, Bridge PD. 2014 - Multilocus gene phylogeny reveals occurrence of Colletotrichum cymbidiicola and C. cliviae on orchids in North East India. Journal of Plant Pathology 96, 327-334.

Corda ACI. 1831 - Die Pilze Deutschlands. In: Sturm J (ed) Deutschlands Flora in Abbildungen nach der Natur mit Beschreibungen. Sturm, Nürnberg vol. 3, Abt. 12, 33-64, tab, 21-32.

Crouch JA, Clarke BB, White JF Jr, Hillman BI. 2009a - Systematic analysis of the falcate-spored graminicolous Colletotrichum and a description of six new species from warm-season grasses. Mycologia 101, 717-732.

Crouch JA, Beirn LA, Cortese LM, Bonos SA, Clarke BB. 2009b - Anthracnose disease of switchgrass caused by the novel fungal species Colletotrichum navitas. Mycological Research 113, 1411-1421.

Crouch JA, Inguagiato JC. 2009 - First report of anthracnose disease of ornamental feather reed grass (Calamagrostis $\times$ acutifolia 'Karl Foerster') caused by Colletotrichum cereale. Plant Disease 93, 203-203.

Crouch JA, Tomaso-Peterson M. 2012 - Anthracnose disease of centipedegrass turf caused by Colletotrichum eremochloae, a new fungal species closely related to Colletotrichum sublineola. Mycologia 104, 1085-1096.

Crouch JA. 2014 - Colletotrichum caudatum s.l. is a species complex. IMA Fungus 5, 1-30.

Crous PW, Denman S, Taylor JE, Swart L, Bezuidenhout CM, Hoffman L, Palm ME, Groenewald JZ. 2013a - Cultivation and disease of Proteaceae: Leucadendron, Leucospermum and Protea: Second Edition. CBS Biodiversity Series, 1-360.

Crous PW, Wingfield MJ, Guarro J, Cheewangkoon R, van der Bank M, Swart WJ, Stchigel AM, Cano-Lira JF, Roux J, Madrid H, Damm U, Wood AR, Shuttleworth LA, Hodges CS, Munster M, de Jesús Yáñez-Morales M, Zúñiga-Estrada L, Cruywagen EM, de Hoog GS, Silvera C, Najafzadeh J, Davison EM, Davison PJN, Barrett MD, Barrett RL, Manamgoda DS, Minnis AM, Kleczewski NM, Flory SL, Castlebury LA, Clay K, Hyde KD, MaússeSitoe SND, Chen S, Lechat C, Hairaud M, Lesage-Meessen L, Pawlowska J, Wilk M, Sliwinska-Wyrzychowska A, Metrak M, Wrzosek M, Pavlic-Zupanc D, Maleme HM, Slippers B, Mac Cormack WP, Archuby DI, Grünwald NJ, Tellería MT, Dueñas M, Martín 
MP, Marincowitz S, de Beer ZW, Perez CA, Gené J, Marin-Felix Y, Groenewald JZ. 2013a - Fungal Planet description sheets: 154-213. Persoonia 31, 188-296.

Crous PW, Wingfield MJ, Guarro J, Hernández-Restrepo, Sutton DA, Acharya K, Barber PA, Boekhout T, Dimitrov RA, Dueñas, Dutta AK, Gené J, Gouliamova DE, Groenewald M, Lombard L, Morozova OV, Sarkar J, Smith MTh, Stchigel AM, Wiederhold NP, Alexandrova AV, Antelmi I, Armengol J, Barnes I, Cano-Lira JF, Ruiz RFC, Contu M, Courtecuisse PrP, da Silveira AL, Decock CA, de Goes A, Edathodu J, Ercole E, Firmino AC, Fourie A, Fournier J, Furtado EL, Geering ADW, Gershenzon J, Giraldo A, Gramaje D, Hammerbacher A, He XL, Haryadi D, Khemmuk W, Kovalenko AE, Krawczynski R, Laich F, Lechat C, Lopes UP, Madrid H, Malsheva EF, Marin-Felix Y, Martin MP, Mostert L, Nigro F, Pereira OL, Picillo B, Pinho DB, Popov ES, Peláez CAR, RooneyLatham S, Sandoval-Denis M, Shivas RG, Silva V, Stoilova-Disheva MM, Telleria MT, Ullah C, Unsicker SB, van der Merwe NA, Vizzini A, Wagner HG, Wong PTW, Wood AR, Groenewald JZ. 2015 - Fungal planet description sheets: 320-370. Persoonia 34, 167266.

Crous PW, Wingfield MJ, Richardson DM, Le Roux JJ, Strasberg D, Edwards J, Roets F, Hubka V, Taylor PWJ, Heykoop M, Martín MP, Moreno G, Sutton DA, Wiederhold NP, Barnes CW, Carlavilla JR, Gené J, Giraldo A, Guarnaccia1 V, Guarro J, Hernández-Restrepo M, Kolařík M, Manjón JL, Pascoe IG, Popov ES, Sandoval-Denis M, Woudenberg JHC, Acharya K, Alexandrova AV, Alvarado P, Barbosa RN, Baseia IG, Blanchette RA, Boekhout T, Burgess TI, Cano-Lira JF, Čmoková A, Dimitrov RA, Dyakov MYu, Dueñas M, Dutta AK, EsteveRaventós F, Fedosova AG, Fournier J, Gamboa P, Gouliamova DE, Grebenc T, Groenewald M, Hanse B, Hardy GESt.J, Held BW, Jurjević Ž, Kaewgrajang T, Latha KPD, Lombard L, Luangsa-ard JJ, Lysková P, Mallátová N, Manimohan P, Miller AN, Mirabolfathy M, Morozova OV, Obodai M, Oliveira NT, Ordóñez ME, Otto EC, Paloi S, Peterson SW, Phosri C, Roux J, Salazar WA, Sánchez A, Sarria GA, Shin H-D, Silva BDB, Silva GA, Smith MTh, Souza-Motta CM, Stchige AM, Stoilova-Disheva MM, Sulzbacher MA, Telleria MT, Toapanta C, Traba JM, Valenzuela-Lopez N, Watling R, Groenewald JZ. 2016 - Fungal Planet description sheets: 400-468. Persoonia 36, 316-458.

Damm U, Woudenberg JHC, Cannon PF, Crous PW. 2009 - Colletotrichum species with curved conidia from herbaceous hosts. Fungal Diversity 39, 45-87.

Damm U, Cannon PF, Woudenberg JHC, Johnston PR, Weir BS, Tan YP, Shivas RG, Crous PW. 2012a - The Colletotrichum boninense species complex. Studies in Mycology 73, 1-36.

Damm U, Cannon PF, Woudenberg JHC, Crous PW. 2012b - The Colletotrichum acutatum species complex. Studies in Mycology 73, 37-113.

Damm U, Cannon PF, Liu F, Barreto RW, Guatimosim E, Crous PW. 2013 - The Colletotrichum orbiculare species complex: important pathogens of field and weeds. Fungal Diversity 61, 29-59.

Damm U, O'Connell RJ, Groenewald JZ, Crous PW. 2014 - The Colletotrichum destructivum species complex - hemibiotrophic pathogens of forage and field crops. Studies in Mycology 79, 49-84.

De Mio LLM, Silva FAD, Blood RY, Figueiredo JAG. 2015 - Twig blight and defoliation caused by Colletotrichum horii in persimmons in Brazil. Revista Brasileira de Fruticultura 37, 256-260.

De Silva DD, Ades PK, Crous PW, Taylor PWJ. 2016 - Colletotrichum species associated with chili anthracnose in Australia. Plant Pathology (available online) http://doi: 10.1111/ppa.12572.

Diao YZ, Fan JR, Wang ZW, Liu XL. 2013 - First report of Colletotrichum boninense causing anthracnose on pepper in China. Physiological and Molecular Plant Pathology 84, 138145.

Diao YZ, Zhang C, Liu F, Wang WZ, Cai L, Liu XL. 2017 - Colletotrichum species causing anthracnose disease of chili in China. Persoonia 38, 20-37. 
Ditmore M, Moore JW, TeBeest DO. 2008 - Interactions of two selected field isolates of Colletotrichum gloeosporioides f. sp. aeschynomene on Aeschynomene virginica. Biological Control 47, 298-308.

Doyle VP, Oudemans PV, Rehner SA, Litt A. 2013 - Habitat and host indicate lineage identity in Colletotrichum gloeosporioides sl. from wild and agricultural landscapes in North America. PLoS One 8, e62394.

Farr DF, Aime MC, Rossman AY, Palm ME. 2006 - Species of Colletotrichum on agavaceae. Mycological Research 110, 1395-1408.

Farr DF, Rossman AY. 2016 - Fungal Databases, Systematic Mycology and Microbiology Laboratory, ARS, USDA. http://nt.ars-grin.gov/fungaldatabases/

Freitas RL, Maciel-Zambolim E, Zambolim L, Lelis DT, Caixeta ET, Lopes UP, Pereira OL. 2013 - Colletotrichum boninense causing anthracnose on Coffee trees in Brazil. Plant Disease 97, 1255-1255.

Garibaldi A, Gilardi G, Ortu G, Gullino ML. 2015 - First report of leaf spot caused by Colletotrichum coccodes on Salvia greggii in Italy. Journal of Plant Pathology 97, 544.

Goodwin PH. 2001 - A molecular weed-mycoherbicide interaction: Colletotrichum gloeosporioides f. sp. malvae and round-leaved mallow, Malva pusilla. Canadian Jouranl of Plant Pathology 23, 28-35.

Guo M, Pan YM, Dai YL, Gao Z-M. 2013 - First Report of Leaf Spot Caused by Colletotrichum spaethianum on Peucedanum praeruptorum in China. Plant Disease 97, 1380.

Hacquard S, Kracher B, Hiruma K, Münch PC, Garrido-Oter R, Thon MR, Weimann A, Damm U, Dallery J-F, Hainaut M, Henrissat B, Lespinet O, Sacristán S, Ver Loren van Themaat E, Kemen E, McHardy AC, Schulze-Lefert P, O’Connell RJ. 2016 - Survival trade-offs in plant roots during colonization by closely related beneficial and pathogenic fungi. Nature Communications 7, article 11362.

Hall TA. 1999 - BioEdit: a user-friendly biological sequence alignment editor and analysis program for Windows 95/98/NT. Nucleic Acids Symposium Series 41, 95-98.

Han KS, Kim BS, Choi IY, Park JH, Shin HD. 2014 - First report of anthracnose caused by Colletotrichum lupini on yellow lupin in Korea. Plant Disease 98, 1158-1158.

Hao W, Wang T, Chen QQ, Chi YK, Swe TM, Qi RD. 2016 - First report of Colletotrichum scovillei causing anthracnose fruit rot on pepper in Anhui Province, China. Plant Disease $100,2168$.

Hawksworth D. 2011 - A new dawn for the naming of fungi: impacts of decisions made in Melbourne in July 2011 on the future publication and regulation of fungal names. MycoKeys 1, 7-20.

He YY, Chen Q, Wu CW, Yang M, Zhou E. 2016 - Colletotrichum truncatum, a new cause of anthracnose on Chinese flowering cabbage (Brassica parachinensis) in China. Tropical Plant Pathology 41, 183-192.

Higginbotham SJ, Arnold AE, Ibanez A, Spadafora C, Coley PD, Kursar TA. 2013 - Bioactivity of fungal endophytes as a function of endophyte taxonomy and the taxonomy and distribution of their host plants. PLoS ONE 8, e73192.

Higgins KL, Coley PD, Kursar TA, Arnold AE. 2011 - Culturing and direct PCR suggest prevalent host generalism among diverse fungal endophytes of tropical forest grasses. Mycologia 103, 247-260

Hillis DM, Bull JJ. 1993 - An empirical test of bootstrapping as a method for assessing confidence in phylogenetic analysis. Systematic Biology 42, 182-192.

Honger JO, Offei SK, Oduro KA, Odamtten GT, Nyaku ST. 2014 - Identification and species status of the mango biotype of Colletotrichum gloeosporioides in Ghana. European Journal of Plant Pathology 140, 455-467.

Hou LW, Liu F, Duan WJ, Cai L. 2016 - Colletotrichum aracearum and C. camelliae-japonicae, two holomorphic new species from China and Japan. Mycosphere 7, 1111-1123. 
Hoz CJP, Calderon C, Rincon AM, Cardenas M, Danies G, Lopez-Kleine L, Restrepo S, Jimenez P. 2016 - Species from the Colletotrichum acutatum, Colletotrichum boninense and Colletotrichum gloeosporioides species complexes associated with tree tomato and mango crops in Colombia. Plant Pathology 65, 227-237.

Hsiao Y, Cheng MJ, Chang HS, Wu MD, Hsieh SY, Liu TW, Lin CH, Yuan GF, Chen IS. 2016 Six new metabolites produced by Colletotrichum aotearoa 09F0161, an endophytic fungus isolated from Bredia oldhamii. Natural Product Research 30, 251-258.

Huang F, Chen GQ, Hou X, Fu YS, Cai L, Hyde KD, Li HY. 2013 - Colletotrichum species associated with cultivated citrus in China. Fungal Diversity 61, 61-74.

Hyde KD, Cai L, McKenzie EHC, Yang YL, Zhang JZ, Prihastuti H. 2009a - Colletotrichum: a catalogue of confusion. Fungal Diversity 39, 1-17.

Hyde KD, Cai L, Cannon PF, Crouch JA, Crous PW, Damm U, Goodwin PH, Chen H, Johnston PR, Jones EBG, Liu ZY, McKenzie EHC, Moriwaki J, Noireung P, Pennycook SR, Pfenning LH, Prihastuti H, Sato T, Shivas RG, Tan YP, Taylor PWJ,Weir BS, Yang YL, Zhang JZ. 2009b - Colletotrichum - names in current use. Fungal Diversity 39, 147-182.

Hyde KD, Nilsson RH, Alias SA, Ariyawansa HA, Blair JE, Cai L, de Cock AWAM, Dissanayake AJ, Glockling SL, Goonasekara ID, Gorczak M, Hahn M, Jayawardena RS, van Kan JAL, Laurence MH, Lévesque CA, Li XH, Liu JK, Maharachchikumbura SSN, Manamgoda DS, Martin FN, McKenzie EHC, McTaggart AR, Mortimer PE, Nair PVR, Pawłowska J, Rintoul TL, Shivas RG, Spies CFJ, Summerell BA, Taylor PWJ, Terhem RB, Udayanga D, Vaghefi N,Walther G,Wilk M,WrzosekM, Xu JC, Yan JY, Zhou N. 2014 - One stop shop: backbones trees for important pytopathogenic genera: I. Fungal Diversity 67, 21-125.

Hyde KD, Hongsanan S, Jeewon R, Bhat DJ, McKenzie EHC, Jones EBG, Phookamsak R, Ariyawansa HA, Boonmee S, Zhao Q, Abdel-Aziz FA, Abdel-Wahab MA, Banmai S, Chomnunti P, Cui BK, Daranagama DA, Das K, Dayarathne MC, de Silva NL, Dissanayake AJ, Doilom M, Ekanayaka AH, Gibertoni TB, Góes-Neto A, Huang SK, Jayasiri SC, Jayawardena RS, Konta S, Lee HB, Li WJ, Lin CG, Liu JK, Lu YZ, Luo ZL, Manawasinghe IS, Manimohan P, Mapook A, Niskanen T, Norphanphoun C, Papizadeh M, Perera RH, Phukhamsakda C, Richter C, de Santiago ALCMA, Drechsler-Santos ER, Senanayake IC, Tanaka K, Tennakoon TMDS, Thambugala KM, Tian Q, Tibpromma S, Thongbai B, Vizzini A, Wanasinghe DN, Wijayawardene NN, Wu H, Yang J, Zeng XY, Zhang H, Zhang JF, Bulgakov TS, Camporesi E, Bahkali AH, Amoozegar AM, AraujoNeta LS, Ammirati JF, Baghela A, Bhatt RP, Bojantchev S, Buyck B, da Silva GA, de Lima CLF, de Oliveira RJV, de Souza CAF, Dai YC, Dima B, Duong TT, Ercole E, Mafalda-Freire F, Ghosh A, Hashimoto A, Kamolhan S, Kang JC, Karunarathna SC, Kirk PM, Kytövuori I, Lantieri A, Liimatainen K, Liu ZY, Liu XZ, Lücking R, Medardi G, Mortimer PE, Nguyen TTT, Promputtha I, Raj KNA, Reck MA, Lumyong S, ShahzadehFazeli SA, Stadler M, Soudi MR, Su HY, Takahashi T, Tangthirasunun N, Uniyal P, Wang Y, Wen TC, Xu JC, Zhang ZK, Zhao YC, Zhou JZ, Zhu L. 2016 - Fungal diversity notes 367-491: taxonomic and phylogenetic contributions to fungal taxa. Fungal Diversity 80, 1270.

Index Fungorum, 2016. http://www.indexfungorum.org/names/names.asp

Jayawardena RS, Hyde KD, Jeewon R, Liu XH, Liu M, Yan JY. 2016a - Why it is important to correctly name Colletotrichum species? Mycosphere 7, 1076-1092.

Jayawardena RS, Huang J, Jin B, Yan JY, Li XH, Hyde KD, Bahkali AH, Yin S, Zhang GZ. 2016c - Morphology and molecular phylogeny updated Colletotrichum species associated with strawberry anthracnose in China. Mycosphere 7, 1147-1163.

Johnson DA, Carris LM, Rogers JD. 1997 - Morphological and molecularcharacterization of Colletotrichum nymphaeae and C. nupharicola sp. nov. onwater-lilies (Nymphaea and Nuphar). Mycological Research 101, 641-649.

Katoh K, Toh H. 2008 - Recent developments in the MAFFT multiple sequence alignment program. Briefings in Bioinformatics 9, 276-285. 
Kasson MT, Pollok JR, Benhase EB, Jelesko JG. 2014 - First report of seedling blight of eastern poison Ivy (Toxicodendron radicans) by Colletotrichum fioriniae in Virginia. Plant Disease 98, 995-995.

Kim WG, Hong SK, Kim JH. 2008 - Occurrence of anthracnose on Chinese mallow caused by Colletotrichum malvarum. Mycobiology 36, 139-141.

Kishino H, Hasegawa M. 1989 - Evaluation of the maximum likelihood estimate of the evolutionary tree topologies from DNA sequence data. Journal of Molecular Evolution 29, 170-179.

Kou LP, Gaskins V, Luo YG, Jurick II WM. 2015 - First report of Colletotrichum fioriniae causing postharvest decay on 'Nittany'apple fruit in the United States. Genetic Resources and Crop Evolution 62, 765-794.

Krishnapillai N, Wilson-Wijeratnam RS. 2014 - First report of Colletotrichum asianum causing anthracnose on Willard mangoes Sri Lanka. New Disease Reports 29, 1.

Kwon J-H, Kim J. 2013 - First report of anthracnose on Rohdea japonica caused by Colletotrichum liriopes in Korea. Plant Disease 97, 559.

Kurt Ş, Uysal A, Akgül DS. 2015 - First report of anthracnose caused by Colletotrichum spinaciae on Spinach in the Mediterranean region of Turkey. Plant Disease 100, 219.

Lei Y, Tang XB, Jayawardena RS, Yan JY, Wang XD, Liu M, Chen T, Liu XM, Wang JC, Chen QX. 2016 - Identification and characterization of Colletotrichum species causing grape ripe rot in Southern China. Mycosphere (This issue).

Lima NB, Barbosa MAG, Hyde KD, Camara MPS, Michereff SJ, de A Batista MV, de Morais Jr MA. 2013 - Five Colletotrichum species are responsible for mango anthracnose in northeastern Brazil. Fungal Diversity 61, 75-88

Li GJ, Hyde KD, Zhao RL, Hongsanan S, Abdel-Aziz FA, Abdel-Wahab MA, Alvarado P, AlvesSilva G, Ammirati JF, Ariyawansa HA, Baghela A, Bahkali AH, Beug M, Bhat DJ, Bojantchev D, Boonpratuang T, Bulgakov TS, Camporesi E, Boro MC, Ceska O, Chakraborty D, Chen JJ, Chethana KWT, Chomnunti P, Consiglio G, Cui BK, Dai DQ, Dai YC, Daranagama DA, Das K, Dayarathne MC, De Crop E, De Oliveira RJV, de Souza CAF, de Souza JI, Dentinger BTM, Dissanayake AJ, Doilom M, Drechsler-Santos ER, Ghobad-Nejhad M, Gilmore SP, Góes-Neto A, Gorczak M, Haitjema CH, Hapuarachchi KK, Hashimoto A, He MQ, Henske JK, Hirayama K, Iribarren MJ, Jayasiri SC, Jayawardena RS, Jeon SJ, Jerônimo GH, Jesus AL, Jones EBG, Kang JC, Karunarathna SC, Kirk PM, Konta S, Kuhnert E, Lagner E, Lee HS, Lee HB, Li WJ, Li XH, Liimatainen K, Lima DX, Lin CG, Liu JK, Liu XZ, Liu ZY, Luangsa-ard JJ, Lücking R, Lumbsch HT, Lumyong S, Leaño EM, Marano AV, Matsumura M, McKenzie EHC, Mongkolsamrit S, Mortimer PE, Nguyen TTT, Niskanen T, Norphanphoun C, O'Malley MA, Parnmen S, Pawlowska J, Perera RH, Phookamsak R, Phukhamsakda C, Pires-Zottarelli CLA, Raspé O, Reck MA, Rocha SCO, de Santiago ALCMA, Senanayake IC, Setti L, Shang QJ, Singh SK, Sir EB, Solomon KV, Song J, Sriktikulchai P, Stadler M, Suetrong S, Takahashi H, Takahashi T, Tanaka K, Tang LP, Thambugala KM, Thanakitpipattana D, Theodorou MK, Thongbai B, Thummarukcharoen T, Tian Q, Tibpromma S, Verbeken A, Vizzini A, Vlasák J, Voigt K, Wanasinghe DN, Wang Y, Weerakoon G, Wen HA, Wen TC, Wijayawardena NN, Wongkanoun S, Wrzosek M, Xiao YP, Xu JC, Yan JY, Yang J, Yang SD, Hu Y, Zhang JF, Zhao J, Zhou LW, Peršoh D, Phillips AJL, Maharachchikumbura SSN. 2016 Fungal diversity notes 253-366: taxonomic and phylogenetic contributions to fungal taxa. Fungal Diversity 78, 1-237.

Liu X, Xie X, Duan J. 2007 - Colletotrichum yunnanense sp. nov., a new endophytic species from Buxus sp. Mycotaxon 100, 137-144.

Liu F, Hyde KD, Cai L. 2011 - Neotypification of Colletotrichum coccodes, the causal agent of potato black dot disease and tomato anthracnose, Mycology 2, 248-254.

Liu F, Cai L, Crous PW, Damm U. 2013a - Circumscription of the anthracnose pathogens Colletotrichum lindemuthianum and C. nigrum. Mycologia 105, 844-860. 
Liu F, Damm U, Cai L, Crous PW. 2013b - Species of the Colletotrichum gloeosporioides complex associated with anthracnose diseases of Proteaceae. Fungal Diversity 61, 89-105.

Liu F, Cai L, Crous PW, Damm U. 2014 - The Colletotrichum gigasporum species complex. Persoonia 33, 83-97.

Liu F, Weir BS, Damm U, Crous PW, Wang Y, Liu B, Wang M, Zhang M, Cai L. 2015a. Unravelling Colletotrichum species associated with Camellia: employing ApMat and GS loci to resolve species in the $C$. gloeosporioides complex. Persoonia 35, 63-86.

Liu F, Wang M, Damm U, Crous PW, Cai L. 2016 - Species boundaries in plant pathogenic fungi: a Colletotrichum case study. BMC Evolutionary Biology 16, article81.

Liu JK, Hyde KD, Jones EBG, Ariyawansa HA, Bhat DJ, Boonmee S, Maharachchikumbura SSN, McKenzie EHC, Phookamsak R, Phukhamsakda C, Shenoy BD, Abdel-Wahab MA, Buyck B, Chen J, Chethana KWT, Singtripop C, Dai DQ, Dai YC, Daranagama DA, Dissanayake AJ, Doilom M, D'souza MJ, Fan XL, Goonasekara ID, Hirayama K, Hongsanan S, Jayasiri SC, Jayawardena RS, Karunarathna SC, Li WJ, Mapook A, Norphanphoun C, Pang KL, Perera RH, Peršoh D, Pinruan U, Senanayake IC, Somrithipol S, Suetrong S, Tanaka K, Thambugala KM, Tian Q, Tibpromma S, Udayanga D, Wijayawardene NN, Wanasinghe D, Wisitrassameewong K, Zeng XY, Abdel-Aziz FA, Adamčík S, Bahkali AH, Boonyuen N, Bulgakov T, Callac P, Chomnunti P, Greiner K, Hashimoto A, Hofsetetter V, Kang JC, Lewis D, Li XH, Liu XZ, Liu ZY, Matsumura M, Mortimer PE, Rambold G, Randrianjohany E, Sato G, Sri-Indrasutdhi V, Tian CM, Verbeken A, von Brackel W, Wang Y, Wen TC, Xu JC, Yan JY, Zhao RL, Camporesi E. 2015b - Fungal diversity notes 1-110: taxonomic and phylogenetic contributions to fungal species. Fungal Diversity 72, $1-197$.

Macedo DM, Pereira OL, Júnior BH, Weir BS, Barreto RW. 2016 - Mycobiota of the weed Tradescantia fluminensis in its native range in Brazil with particular reference to classical biological control. Australasian Plant Pathology 45, 45-56.

Maharachchikumbura SSN, Hyde KD, Jones EBG, McKenzie EHC, Huang S-K, Abdel-Wahab MA, Daranagama DA, Dayarathne M, D' souza MJ, Goonasekara ID, Hongsanan S, Jayawardena RS, Kirk PM, Konta S, Liu J-K, Liu Z-Y, Norphanphoun C, Shenoy BD, Xiao Y, Bahkali AH, Kang J, Somrothipol S, Suetrong S, Wen T, Xu J. 2015 - Towards a natural classification and backbone tree for Sodariomycetes. Fungal Diversity 72, 199-301.

Maharachchikumbura SN, Hyde KD, Jones EBG, McKenzie EHC, Bhat JD, Dayarathne MC, Huang SK, Norphanphoun C, Senanayake IC, Perera RH, Shang QJ, Xiao Y, D'souza MJ, Hongsanan S, Jayawardena RS, Daranagama DA, Konta S, Goonasekara ID, Zhuang WY, Jeewon R, Phillips AJL, Abdel-Wahab MA, Al-Sadi AM, Bahkali Ah, Boonmee S, Boonyuen N, Cheewangkoon R, Dissanayake AJ, Kang J, Li QR, Liu JK, Liu XZ, Liu ZY, Luangsa-ard JJ, Pang KL, Phookamsak R, Promputtha I, Suetrong S, Stadler M, Wen T, Wijayawardene NN. 2016 - Families of Sordariomycetes. Fungal Diversity 79, 1-317.

Manamgoda DS, Udayanga D, Cai L, Chukeatirote E, Hyde KD. 2013 - Endophytic Colletotrichum from tropical grasses with a new species $C$. endophytica. Fungal Diversity 61, 107-115.

Marcelino J, Giordano R, Gouli S, Gouli V, Parker BL, Skinner M, TeBeest D, Cesnik R. 2008 Colletotrichum acutatum var. foriniae (teleomorph: Glomerella acutata var. foriniae var. nov. infection of a scale insect. Mycologia 100, 353-374.

McCormack JE, Huang H, Knowles LL. 2009 - Maximum likelihood estimates of species trees: how accuracy of phylogenetic inference depends upon the divergence history and sampling design. Systematic Biology 58, 501-508.

Moriwaki J, Tsukiboshi T. 2009 - Colletotrichum echinochloae, a new species on Japanese barnyard millet (Echinochloa utilis). Mycoscience 50, 273-280.

Morsy AA, Elshahawy IE. 2016 - Anthracnose of lucky bamboo Dracaena sanderiana caused by the fungus Colletotrichum dracaenophilum in Egypt. Journal of Advanced Research 7, 327-335. 
Mosca S, Nicosia MGLD, Cacciola SO, Schena L. 2014 - Molecular analysis of Colletotrichum species in the carposphere and phyllosphere of olive. PloS One 9, e114031.

Munda A. 2014 - First report of Colletotrichum fioriniae and C. godetiae causing apple bitter rot in Slovenia. Plant Disease 98, 1282-1282.

Nakamura M, Ohzono M, Iwai H, Arai K. 2006 - Anthracnose of Sansevieria trifasciata caused by Colletotrichum sansevieriae sp. nov. Journal of General Plant Pathology 72, 253-256.

NagRaj TR. 1993 - Coelomtycetous anamorphs with appendage-bearing conidia. Mycologue Publications, Waterloo, Ontalario, Canada. 220-221.

Niu X-P, Gao H, Qi J-M, Chen M-C, Tao A-F, Xu J-T, Dai Z-G, Su J-G. 2016 - Colletotrichum species assciated with jute (Corchorus capsularis L.) anthracnose in southeastern China. Scientific Report 6, article 25179.

Noireung P, Phoulivong S, Liu F, Cai L, Mckenzie EH, Chukeatirote E, Jones EBG, Bahkali, AH, Hyde KD. 2012 - Novel species of Colletotrichum revealed by morphology and molecular analysis. Cryptogamie Mycologie 33, 347-362.

Nylander JAA. 2004 - MrModeltest 2.0. Program distributed author. Evolutionary Biology Centre, Uppsala University.

O'Connell RJ, Thon MR, Hacquard S, Amyotte SG, Kleemann J, Torres MF, Damm U, Buiate EA, Epstein L, Alkan N, Altmüller, Alvarado-Balderrama L, Bauser CA, Becker C, Birren BW, Chen Z, Choi J, Crouch JA, Duvick JP, Farman MA, Gan P, Heiman D, Henrissat B, Howard RJ, Kabbage M, Koch C, Kracher B, Kubo Y, Law AD, Lebrun MH, Lee YH, Miyara I, Moore N, Neumann U, Nordström, Panaccione DG, Panstruga R, Place M, Proctor RH, Prusky D, rech G, Reinhardt R, Rollins JA, Rounsley S, Schardl CL, Schwartz DC, Shenoy N, Shirasu K, Sikhakolli UR, Stüber K, Sukno SA, Sweigard JA, Takano Y, Takahara H, Trail F, Zhou S, Dickman MB, Schulze-Lefert P, Loren van Themaat EV, Ma LJ, Vaillancourt LJ. 2012 - Life-style transitions in plant pathogenic Colletotrichum fungi deciphered by genome and transcriptome analyses. Nature Genetics 44, 1060-1065.

Panaccione DG, Vaillancourt LJ, Hanau RM. 1989 - Conidial dimorphism in Colletotrichum graminicola. Mycologia 81, 876-883.

Palmateer AJ, Tarnowski TLB, Lopez P. 2012 - First report of Colletotrichum sansevieriae causing anthracnose of Sansevieria trifasciata in Florida. Plant Disease 96, 293.

Park JH, Han KS, Kim JY, Shin HD. 2013 - First report of anthracnose caused by Colletotrichum sansevieriae on Sansvieria in Korea. Plant Disease 97, 1510.

Paul NC, Lee HB, Lee JH, Shin KS, Ryu TH, Kwon HR, Kim YK, Youn YN, Yu SH. 2014 Endophytic fungi from Lycium chinense Mill and characterization of two new Korean records of Colletotrichum. International Journal of Molecular Science 15, 15272-15286.

Peng LJ, Yang YL, Hyde KD, Bahkali AH, Liu ZY. 2012 -Colletotrichum species on Citrus leaves in Guizhou and Yunnan provinces, China. Cryptogamie Mycologie 33, 267-283.

Peng LJ, Sun T, Yang YL, Cai L, Hyde KD, Bahkali HA, Liu ZY. 2013 - Colletotrichum species on grape in Guizhou and Yuannan provinces, China. Mycoscience 54, 29-41.

Phoulivong S, Cai L, Chen H, McKenzie EHC, Abdelsalam K, Chukeatirote E, Hyde KD. 2010 Colletotrichum gloeosporioides is not a common pathogen on tropical fruits. Fungal Diversity 44, 33-43.

Politis DJ. 1975 - The identity and perfect state of Colletotrichum graminicola. Mycologia 67, 5662.

Prihastuti H, Cai L, Chen H, McKenzie EHC, Hyde KD. 2009 - Characterization of Colletotrichum species associated with coffee berries in Northern Thailand. Fungal Diversity 39, 89-109.

Prihastuti H, Cai L, Crouch JA, Phoulivong S, Moslem MA, McKenzie EHC, Hyde KD. 2010 Neotypification of Colletotrichum falcatum, the causative agent of red-rot disease in sugarcane. Sydowia 62, 283-293.

Rakotoniriana EF, Scauflaire J, Rabemanantsoa C, Urveg-Ratsimamanga S, Corbisier AM, QuetinLeclercq J, Declerck S, Munaut F. 2013 - Colletotrichum gigasporum sp. nov., a new 
species of Colletotrichum producing long straight conidia. Mycological Progress 12: 403 412.

Réblová M, Gams W, Seifert KA. 2011 - Monilochaetes and allied genera of the Glomerellales, and a reconsideration of families in the Microascales. Studies in Mycology 68, 163-191.

Rhaiem A, Taylor PWJ. 2016 - Colletotrichum gloeosporioides associated with anthracnose symptoms on citrus, a new report for Tunisia. European Journal of Plant Pathology 146, 219-224.

Ritterband DC, Shah M, Seedor JA. 1997 - Colletotrichum graminicola: a new corneal pathogen. Cornea 16, 362-364.

Rojas EI, Rehner SA, Samuels GJ, Van Bael SA, Herre EA, Cannon P, Chen R, Pang J, Wang R, Zhang Y, Peng YQ. 2010 - Colletotrichum gloeosporioides s. 1. associated with Theobroma cacao and other plants in Panama: multilocus phylogenies distinguish pathogen and endophyte clades. Mycologia 102, 1318-1338.

Ronquist F, Huelsenbeck JP. 2003 - MrBayes 3: Bayesian phylogenetic inference under mixed models. Bioinformatics 19, 1572-1574.

Rosskopf EN, Hong J, Kokalis-Burelle N. 2014 - First report of Colletotrichum lupini on Lupinus hartwegii and L. mutabilis. Plant Disease 98, 161.

Sakinah MI, Suzianti IV, Latiffah Z. 2014 - Phenotypic and molecular characterization of Colletotrichum species associated with anthracnose of banana (Musa spp.) in Malaysia. Genetics and Molecular Research 13, 3627-3637.

Samac DA, Allen S, Witte D, Miller D, Peterson J. 2014 - First report of race 2 of Colletotrichum trifolii causing anthracnose on alfalfa (Medicago sativa) in Wisconsin. Plant Disease 98, 843.

Santana KFA, Garcia CB, Matos KS, Hanada RE, Silva GF, Sousa NR. 2016 - First report of anthracnose caused by Colletotrichum spaethianum on Allium fistulosum in Brazil. Plant Disease 100, 224-225.

Sato T, Muta T, Imamura Y, Nojima H, Moriwaki J, Yaguchi Y. 2005 - Anthracnose of Japanese radish caused by Colletotrichum dematium. Journal of General Plant Pathology 71, 380383.

Sato T, Moriwaki J, Uzuhashi S, Degawa Y, Ono T, Nishimura K. 2012 - Molecular phylogenetic analyses and morphological re-examination of strains belonging to three rare Colletotrichum species in Japan. Microbiology and Culture Collections 28, 121-134.

Schena L, Mosca S, Cacciola SO, Faedda R, Sanzani SM, Agosteo GE, Sergeeva V, Magnano di San Lio G. 2014 - Species of the Colletotrichum gloeosporioides and C. boninense complexes associated with olive anthracnose. Plant Pathology 63, 437-446.

Schwarczinger I, Vajna L, Bruckart WL. 1998 - First report of Colletotrichum gloeosporioides on Russian thistle. Plant Disease 82, 1405.

Sharma G, Gryzenhout M, Hyde KD, Pinnaka AK, Shenoy BD. 2013 - First report of Colletotrichum asianum causing mango anthracnose in South Africa. Plant Disease 99, 725.

Sharma K, Goss E, van Bruggen AH. 2014 - Isolation and identification of the fungus Colletotrichum cordylinicola causing anthracnose disease on Cordyline fruticosa in Florida. HortScience 49, 911-916.

Sharma G, Kumar-Pinnaka A, Shenoy BD. 2015 - Resolving the Colletotrichum siamense species complex using ApMat marker. Fungal Diversity 71, 247-264.

Shenoy BD, Jeewon R, Lam WH, Bhat DJ, Than PP, Taylor PWJ, Hyde KD. 2007 - Morphomolecular characterisation and epitypification of Colletotrichum capsici (Glomerellaceae, Sordariomycetes), the causative agent of anthracnose in chilli. Fungal Diversity 27, 197211.

Shivas RG, Bathgate J, Podger FD. 1998 - Colletotrichum xanthorrhoeae sp. nov. on Xanthorrhoea in Western Australia. Mycological Research 102, 280-282. 
Shivas RG, Tan YP. 2009 - A taxonomic re-assessment of Colletotrichum acutatum, introducing C. fioriniae comb. et stat. nov. and C. simmondsii sp. nov. Fungal Diversity 39, 111-112.

Silva-Rojas HV, Ávila-Quezada GD. 2011 - Phylogenetic and morphological identification of Colletotrichum boninense: a novel causal agent of anthracnose in avocado. Plant Pathology 60, 899-908.

Silvestro D, Michalak I. 2010 - raxmlGUI: a graphical front-end for RAxML. http://sourceforge.net/projects/raxmlgui/

Squissato V, Yucel YH, Richardson SE, Alkhotani A, Wong DT, Nijhawan N, Chan CC. 2015 Colletotrichum truncatum species complex: Treatment considerations and review of the literature for an unusual pathogen causing fungal keratitis and endophthalmitis. Medical Mycology Case Reports 9, 1-6.

Su YY, Noireung P, Liu F, Hyde KD, Moslem MA, Bahkali AH, Abd-Elsalam KA, Cai L. 2011 Epitypification of Colletotrichum musae, the causative agent of banana anthracnose. Mycoscience 52, 376-382.

Sun X, Guo L-D, Hyde KD. 2012 - Community composition of endophytic fungi in Acer truncatum and their role in decomposition. Fungal Diversity 47, 85-95.

Sutton BC. 1980 - The Coelomycetes. Fungi Imperfecti with Pycnidia, Acervuli and Stromata. Commonwealth Mycological Institute, Kew, Surrey, England, 1-696.

Sutton BC. 1992 - The genus Glomerella and its anamorph Colletotrichum. In: Colletotrichum: Biology, Pathology and Control (Bailey JA, Jeger MJ, eds). CABI, Wallingford, UK: 1-26.

Swofford DL. 2002 - PAUP* 4.0: phylogenetic analysis using parsimony (*and other methods). Sinauer Associates, Sunderland.

Talhinhas P, Gonçalves E, Sreenivasaprasad S, Oliveira H. 2015 - Virulence diversity of anthracnose pathogens (Colletotrichum acutatum and C. gloeosporioides species complexes) on eight olive cultivars commonly grown in Portugal. European Journal of Plant Pathology 142, 73-83.

Tao G, Liu ZY, Liu F, Gao YH, Cai L. 2013 - Endophytic Colletotrichum species from Bletilla ochracea (Orchidaceae), with description of seven new species. Fungal Diversity 61, 139164.

Thompson JD, Gibson TJ, Plewniak F, Jeanmougin F, Higgins DG. 1997 - The Clustal X windows interface: flexible strategies for multiple sequence alignment aided by quality analysis tools. Nucleic Acids Research 24, 4876-4882.

Tozze Jr HJ, Fischer IH, Camara MPS, Massola Jr NS. 2010 - First report of Colletotrichum boninense infecting yellow passion fruit (Passiflora edulis f. flavicarpa) in Brazil. Australasian Plant Disease Notes 5, 70-72.

Uematsu S, Kageyama K, Moriwaki J, Sato T. 2012 - Colletotrichum carthami comb. nov., an anthracnose pathogen of safflower, garland chrysanthemum and pot marigold, revived by molecular phylogeny with authentic herbarium species. Journal of Genetic Plant Pathology 78, 316-330.

Udayanga D, Manamgoda DS, Liu X-Z, Chukeatirote E, Hyde KD. 2013 - What are the common anthracnose pathogens of tropical fruits?. Fungal Diversity 61, 165-179.

Vega FE, Simpkins A, Aime MC, Posada F, Peterson SW, Rehner SA, Infante F, Castillo A, Arnold AE. 2010 - Fungal endophyte diversity in coffee plants from Colombia, Hawai'i, Mexico and Puerto Rico. Fungal Ecology 3, 122-138.

Velho AC, Stadnik MJ, Casanova L, Mondino P, Alaniz S. 2014 - First report of Colletotrichum nymphaeae causing apple bitter rot in southern Brazil. Plant Disease 98, 567.

Velho AC, Alaniz S, Casanova L, Mondino P, Stadnik MJ. 2015 - New insights into the characterization of Colletotrichum species associated with apple diseases in southern Brazil and Uruguay. Fungal Biology 119, 229-244.

Vieira WAS, Nascimento RJ, Michereff SJ, Hyde KD, Camara MPS. 2013 - First report of Papaya fruit anthracnose caused by Colletotrichum brevisporum in Brazil. Plant Disease 97, 1659. 
Vieira WAS, Michereff SJ, de Morais Jr MA, Hyde KD, Camara MPS. 2014a - Endophytic species of Colletotrichum associated with mango in northeastern Brazil. Fungal Diversity 67, 181202.

Vieira WAS, Michereff SJ, Oliveira AC, Santos A, Camara MPS. 2014b - First report of anthracnose caused by Colletotrichum spaethianum on Hemerocallis flava in Brazil. Plant Disease 98, 997.

Waller JM, Bridge PD, Black R, Hakiza G. 1993 - Characterisation of the coffee berry disease pathogen, Colletotrichum kahawae sp. nov. Mycological Research 97, 989-994.

Wang YC, Hao XY, Wang L, Xiao B, Wang XC, Yang YJ. 2016 - Diverse Colletotrichum species cause anthracnose of tea plants (Camellia sinensis (L.) O. Kuntze) in China. Scientific reports 6 , article 35287 .

Weir BS, Johnston PR. 2010 - Characterisation and neotypification of Gloeosporium kaki Hori as Colletotrichum horii nom. nov. Mycotaxon 111, 209-219.

Weir BS, Johnston PR, Damm U. 2012 - The Colletotrichum gloeosporioides species complex. Studies in Mycology 73, 115-180.

Wikee S, Cai L, Pairin N, McKenzie EHC, Su YY, Chukeatirote E, Thi HN, Bahkali AH, Moslem MA, Abdelsalam K, Hyde KD. 2011 - Colletotrichum species from Jasmine (Jasminum sambac). Fungal Diversity 46, 171-182.

Wijesundera RLC, Chandrasekharan NV, Wijesundera WSS, Kathriarachchi HS, Fernando THPS. 2015 - Characterization of Colletotrichum isolates causing avocado anthracnose and first report of C. gigasporum infecting avocado in Sri Lanka. Plant Pathology \& Quarantine 5, $132-143$.

Xia-Ying L, Xiang-Ming X, Jun-Xing D. 2007 - Colletotrichum yunnanense sp. nov., a new endophytic species from Buxus sp. Mycotaxon 100, 137-144.

Xu S, Li YZ. 2015 - First report of common vetch anthracnose caused by Colletotrichum lentis in China. Plant Disease 99, 1859.

Yang H-C, Haudenshield JS, Hartman GL. 2014 - Colletotrichum incanum sp. nov., a curvedconidial species causing soybean anthracnose in USA. Mycologia 106, 32- 42.

Yang HC, Haudenshield JS, Hartman GL. 2012b - First report of Colletotrichum chlorophyti causing soybean anthracnose. Plant Disease 96, 1699.

Yang YL, Liu ZY, Cai L, Hyde KD, Yu ZN, McKenzie EHC. 2009 - Colletotrichum anthracnose of Amaryllidaceae. Fungal Diversity 39, 123-146.

Yang YL, Cai L, Yu ZN, Liu ZY, Hyde KD. 2011 - Colletotrichum species on orchids in southwest China. Cryptogamie Mycologie 32, 229-253.

Yang Y, Liu Z, Cai L, Hyde KD. 2012a - New species and notes of Colletotrichum on daylilies (Hemerocallis spp.). Tropical Plant Pathology 37, 165-174.

Yan JY, Jayawardena MMRS, Goonasekara ID, Wang Y, Zhang W, Liu M, Huang J-B, Wang Z-Y, Shang J-J, Peng Y-L, Bahkali A, Hyde KD, Li XH. 2015 - Diverse species of Colletotrichum associated with grapevine anthracnose in China. Fungal Diversity 71, 233246.

Young JR, Tomaso-Peterson M, Crouch JA. 2008 - First report of Colletotrichum cereale causing anthracnose foliar blight of creeping bentgrass in Mississippi and Alabama. Plant Disease $92,1475$.

Zakaria L, Juhari NZ, Vijaya SI, Anuar ISM. 2015 - Molecular characterization of Colletotrichum isolates associated with anthracnose of mango fruit. Sains Malaysiana 44, 651-656.

Zhang FF, Wang MZ, Zheng YX, Liu HY, Zhang XQ, Wu SS. 2015 - Isolation and characterzation of endophytic Huperzine-A producing fungi from Phlegmariurus phlegmaria. Microbiology 84, 701-709.

Zhao MN, Qiu HP, Jiang H, Zhang Z, Mao XQ, Wang JY, Chari RY, Du XF, Wang YL, Sun GC. 2012 - Optimization of fermentation conditions of biocontrol strain Col-68 Colletotrichum hanaui against Digitaria sanguinalis. Acta Agriculturae Zhejiangensis 3, 021. 
Zhou RJ, Yuan Y, Xu HJ, Fu JF, Ou YH. 2014 - First report of anthracnose of Malva sylvestris caused by Colletotrichum trifolii in China. Plant Disease 98, 1587. 
Table 1 GenBank accession Numbers of the accepted Colletotrichum species

\begin{tabular}{|c|c|c|c|c|c|c|c|c|c|c|c|c|c|}
\hline \multirow{2}{*}{ Species Name } & \multirow[t]{2}{*}{ Isolate No } & \multicolumn{12}{|c|}{ GenBank Accession Numbers } \\
\hline & & ITS & GAPDH & CHS-1 & HIS3 & $\mathrm{ACT}$ & TUB2 & CAL & GS & SOD2 & ApMat & Apn2 & Mat 1 \\
\hline C. abscissum & COAD $1877 *$ & $\begin{array}{l}\text { KP84312 } \\
6\end{array}$ & $\begin{array}{l}\text { KP84312 } \\
9\end{array}$ & KP843132 & KP843138 & KP843141 & KP843135 & - & - & - & - & - & - \\
\hline C. acerbum & CBS $128530^{*}$ & $\begin{array}{l}\text { JQ94845 } \\
9\end{array}$ & $\begin{array}{l}\text { JQ94879 } \\
0\end{array}$ & JQ949120 & JQ949450 & JQ949780 & JQ950110 & - & - & - & - & - & - \\
\hline C. acutatum & CBS $112996^{*}$ & $\begin{array}{l}\text { JQ00577 } \\
6\end{array}$ & $\begin{array}{l}\text { JQ94867 } \\
7\end{array}$ & JQ005797 & JQ005818 & JQ005839 & JQ005860 & - & - & - & - & - & - \\
\hline C. aenigma & ICMP 18608* & $\begin{array}{l}\text { JX01024 } \\
4\end{array}$ & $\begin{array}{l}\text { JX01004 } \\
4\end{array}$ & JX009774 & - & JX009443 & JX010389 & JX009683 & $\begin{array}{l}\text { JX01007 } \\
8\end{array}$ & $\begin{array}{l}\text { JX01031 } \\
1\end{array}$ & $\begin{array}{l}\text { KM36014 } \\
3\end{array}$ & - & - \\
\hline C. aeschynomenes & ICMP 17673* & $\begin{array}{l}\text { JX01017 } \\
6\end{array}$ & $\begin{array}{l}\text { JX00993 } \\
0\end{array}$ & JX009799 & - & JX009483 & JX010392 & JX009721 & $\begin{array}{l}\text { JX01008 } \\
1\end{array}$ & $\begin{array}{l}\text { JX01031 } \\
4\end{array}$ & - & - & - \\
\hline C. agaves & CBS 118190 & $\begin{array}{l}\text { DQ2862 } \\
21\end{array}$ & - & - & - & - & - & - & - & - & - & - & - \\
\hline C. alatae & ICMP 17919* & $\begin{array}{l}\text { JX01019 } \\
0\end{array}$ & $\begin{array}{l}\text { JX00999 } \\
0\end{array}$ & JX009837 & - & JX009471 & JX010383 & JX009738 & $\begin{array}{l}\text { JX01006 } \\
5\end{array}$ & $\begin{array}{l}\text { JX01030 } \\
5\end{array}$ & $\begin{array}{l}\text { KC } 88893 \\
2\end{array}$ & - & - \\
\hline C. alienum & ICMP $12071 *$ & $\begin{array}{l}\text { JX01025 } \\
1\end{array}$ & $\begin{array}{l}\mathrm{JX} 01002 \\
8\end{array}$ & JX009882 & - & JX009572 & JX010411 & JX009654 & $\begin{array}{l}\text { JX01010 } \\
1\end{array}$ & $\begin{array}{l}\text { JX01033 } \\
3\end{array}$ & $\begin{array}{l}\text { KM36014 } \\
4\end{array}$ & - & - \\
\hline C. alcornii & IMI 1766192* & $\begin{array}{l}\text { JX07685 } \\
8\end{array}$ & - & - & - & - & - & - & - & - & - & - & - \\
\hline $\begin{array}{l}\text { C. americae- } \\
\text { borealis }\end{array}$ & CBS $136232 *$ & $\begin{array}{l}\text { KM1052 } \\
24\end{array}$ & $\begin{array}{l}\text { KM1055 } \\
79\end{array}$ & $\begin{array}{l}\text { KM10529 } \\
4\end{array}$ & KM105364 & $\begin{array}{l}\text { KM10543 } \\
4\end{array}$ & KM105504 & - & - & - & - & - & - \\
\hline C. annellatum & CBS 129826* & $\begin{array}{l}\text { JQ00522 } \\
2\end{array}$ & $\begin{array}{l}\text { JQ00530 } \\
9\end{array}$ & JQ005396 & JQ005483 & JQ005570 & JQ005656 & JQ005743 & - & - & - & - & - \\
\hline C. anthrisci & CBS 125334* & $\begin{array}{l}\text { GU2278 } \\
45\end{array}$ & $\begin{array}{l}\text { GU2282 } \\
37\end{array}$ & $\begin{array}{l}\text { GU22833 } \\
5\end{array}$ & - & GU227943 & GU228139 & - & - & - & - & - & - \\
\hline
\end{tabular}




\begin{tabular}{|c|c|c|c|c|c|c|c|c|c|c|c|c|c|}
\hline \multirow[t]{2}{*}{ Species Name } & \multirow[t]{2}{*}{ Isolate No } & \multicolumn{12}{|c|}{ GenBank Accession Numbers } \\
\hline & & ITS & GAPDH & CHS-1 & HIS3 & $\mathrm{ACT}$ & TUB2 & CAL & GS & SOD2 & ApMat & Apn2 & Mat1 \\
\hline \multirow{2}{*}{ C. antirrhinicola } & & KM1051 & KM1055 & KM10525 & & KM10539 & & & & & & & \\
\hline & CBS $102189 *$ & 80 & 31 & 0 & KM105320 & 0 & KM105460 & - & - & - & - & - & - \\
\hline \multirow{2}{*}{ C. aotearoa } & & JX01020 & JX01000 & & & & & & JX01011 & JX01034 & KC88893 & & \\
\hline & ICMP $18537 *$ & 5 & 5 & JX009853 & - & JX009564 & JX010420 & JX009611 & 3 & 5 & 0 & - & - \\
\hline \multirow{2}{*}{ C. aracearum } & CGMCC & KX8531 & KX8935 & & & & & & & & & & \\
\hline & $3.14982 *$ & 67 & 86 & - & - & KX893578 & KX893582 & - & - & - & - & - & - \\
\hline \multirow{2}{*}{ C. arxii } & & KF68771 & KF68784 & & & & & & KF68775 & & & & \\
\hline & CBS $132511 *$ & 6 & 3 & KF687780 & - & KF687802 & KF687881 & KF687819 & 6 & - & - & - & - \\
\hline \multirow{2}{*}{ C. asianum } & & FJ97261 & JX01005 & & & & & & JX01009 & JX01032 & & & \\
\hline & ICMP 18580* & 2 & 3 & JX009867 & - & JX009584 & JX010406 & FJ917506 & 6 & 8 & FR718814 & - & - \\
\hline \multirow{2}{*}{ C. australe } & & JQ94845 & JQ94878 & & & & & & & & & & \\
\hline & CBS $116478^{*}$ & 5 & 6 & JQ949116 & JQ949446 & JQ949776 & JQ950106 & - & - & - & - & - & - \\
\hline \multirow{2}{*}{ C. axonopodi } & & EU55408 & & & & & & & & & & & \\
\hline & IMI 279189* & 6 & - & - & - & - & - & - & - & - & - & - & - \\
\hline \multirow{2}{*}{ C. baltimorense } & & JX07686 & & & & & & & & JX07688 & & JX0769 & \\
\hline & BPI892771* & 6 & - & - & - & - & - & - & - & 6 & - & 27 & JX076905 \\
\hline \multirow{2}{*}{ C. beeveri } & & JQ00517 & JQ00525 & & & & & & & & & & \\
\hline & CBS $128527 *$ & 1 & 8 & JQ005345 & JQ005432 & JQ005519 & JQ005605 & JQ005692 & - & - & - & - & - \\
\hline \multirow{2}{*}{ C. bidentis } & & KF17848 & KF17850 & & & & & & KF17862 & & & & \\
\hline & COAD $1020 *$ & 1 & 6 & KF178530 & KF178554 & KF178578 & KF178602 & - & 7 & - & - & - & - \\
\hline \multirow{2}{*}{ C. bletillum } & CGMCC & JX62517 & KC8435 & & & & & & & & & & \\
\hline & $3.15117^{*}$ & 8 & 06 & - & - & KC843542 & JX625207 & - & - & - & - & - & - \\
\hline \multirow{2}{*}{ C. boninense } & & JQ00515 & JQ00524 & & & & & & & & & & \\
\hline & CBS $123755^{*}$ & 3 & 0 & JQ005327 & JQ005414 & JQ005501 & JQ005588 & JQ005674 & - & - & - & - & - \\
\hline \multirow{2}{*}{ C. brasiliense } & & JQ00523 & JQ00532 & & & & & & & & & & \\
\hline & CBS $128501 *$ & 5 & 2 & JQ005409 & JQ005496 & JQ005583 & JQ005669 & JQ005756 & - & - & - & - & - \\
\hline C. brassicola & CBS $101059 *$ & JQ00517 & JQ00525 & JQ005346 & JQ005433 & JQ005520 & JQ005606 & JQ005693 & - & - & - & - & - \\
\hline
\end{tabular}




\begin{tabular}{|c|c|c|c|c|c|c|c|c|c|c|c|c|c|}
\hline \multirow[t]{2}{*}{ Species Name } & \multirow[t]{2}{*}{ Isolate No } & \multicolumn{12}{|c|}{ GenBank Accession Numbers } \\
\hline & & ITS & GAPDH & CHS-1 & HIS3 & ACT & TUB2 & CAL & GS & SOD2 & ApMat & Apn2 & Mat1 \\
\hline & & 2 & 9 & & & & & & & & & & \\
\hline C. brevisporum & BCC $38876^{*}$ & $\begin{array}{l}\text { JN05023 } \\
8\end{array}$ & $\begin{array}{l}\text { JN05022 } \\
7\end{array}$ & KF687760 & - & JN050216 & JN050244 & - & - & - & - & - & - \\
\hline C. brisbanense & CBS $292.67^{*}$ & $\begin{array}{l}\text { JQ94829 } \\
1\end{array}$ & $\begin{array}{l}\text { JQ94862 } \\
1\end{array}$ & JQ948952 & JQ949282 & JQ949612 & JQ949942 & - & - & - & - & - & - \\
\hline C. bryoniicola & CBS $109849 *$ & $\begin{array}{l}\text { KM1051 } \\
81\end{array}$ & $\begin{array}{l}\text { KM1055 } \\
32\end{array}$ & $\begin{array}{l}\text { KM10525 } \\
1\end{array}$ & KM105321 & $\begin{array}{l}\text { KM10539 } \\
1\end{array}$ & KM105461 & - & - & - & - & - & - \\
\hline C. cairnsense & BRIP $63642 *$ & $\begin{array}{l}\text { KU9236 } \\
72\end{array}$ & $\begin{array}{l}\text { KU9237 } \\
04\end{array}$ & $\begin{array}{l}\text { KU92371 } \\
0\end{array}$ & KU923722 & KU923716 & KU923688 & - & - & - & - & - & - \\
\hline C. camelliae & $\begin{array}{l}\text { CGMCC } \\
3.14925^{*}\end{array}$ & $\begin{array}{l}\text { KJ95508 } \\
1\end{array}$ & $\begin{array}{l}\text { KJ95478 } \\
2\end{array}$ & - & - & KJ954363 & KJ955230 & KJ954634 & $\begin{array}{l}\text { KJ95493 } \\
2\end{array}$ & - & KJ954497 & - & - \\
\hline $\begin{array}{l}\text { C. camelliae- } \\
\text { japonicae }\end{array}$ & $\begin{array}{l}\text { CGMCC3.18118 } \\
*\end{array}$ & $\begin{array}{l}\text { KX8531 } \\
65\end{array}$ & $\begin{array}{l}\text { KX8935 } \\
84\end{array}$ & - & - & KX893576 & KX893580 & - & - & - & - & - & - \\
\hline C. carthami & SAPA100011* & $\begin{array}{l}\text { AB6969 } \\
98\end{array}$ & - & - & - & - & AB696992 & - & - & - & - & - & - \\
\hline C. caudatum & CBS13602* & $\begin{array}{l}\text { JX07686 } \\
0\end{array}$ & - & - & - & - & - & - & - & $\begin{array}{l}\text { JX07687 } \\
8\end{array}$ & - & $\begin{array}{l}\text { JX0769 } \\
32\end{array}$ & JX076893 \\
\hline C. caudasporum & $\begin{array}{l}\text { CGMCC } \\
3.15106 *\end{array}$ & $\begin{array}{l}\text { JX62516 } \\
2\end{array}$ & $\begin{array}{l}\text { KC } 8435 \\
12\end{array}$ & - & - & KC843526 & JX625190 & - & - & - & - & - & - \\
\hline C. cereale & CBS 129663* & $\begin{array}{l}\text { JQ00577 } \\
4\end{array}$ & - & JQ005795 & JQ005816 & JQ005837 & JQ005858 & - & - & - & - & - & - \\
\hline C. chengpingense & $\begin{array}{l}\text { MFLUCC 15- } \\
0022^{*}\end{array}$ & $\begin{array}{l}\text { KP68315 } \\
2\end{array}$ & $\begin{array}{l}\text { KP85246 } \\
9\end{array}$ & KP852449 & - & KP683093 & KP852490 & - & - & - & - & - & - \\
\hline C. chlorophyti & IMI 103806* & $\begin{array}{l}\text { GU2278 } \\
94\end{array}$ & $\begin{array}{l}\text { GU2282 } \\
86\end{array}$ & $\begin{array}{l}\text { GU22838 } \\
4\end{array}$ & - & GU227992 & GU228188 & - & - & - & - & - & - \\
\hline C. chrysanthemi & CBS $126518^{*}$ & $\begin{array}{l}\text { JQ94827 } \\
1\end{array}$ & $\begin{array}{l}\text { JQ94860 } \\
1\end{array}$ & JQ948932 & JQ949262 & JQ949592 & JQ949922 & - & - & - & - & - & - \\
\hline
\end{tabular}




\begin{tabular}{|c|c|c|c|c|c|c|c|c|c|c|c|c|c|}
\hline \multirow[t]{2}{*}{ Species Name } & \multirow[t]{2}{*}{ Isolate No } & \multicolumn{12}{|c|}{ GenBank Accession Numbers } \\
\hline & & ITS & GAPDH & CHS-1 & HIS3 & $\mathrm{ACT}$ & TUB2 & CAL & GS & SOD2 & ApMat & Apn2 & Mat1 \\
\hline \multirow{2}{*}{ C. circinans } & & GU2278 & GU2282 & GU22834 & & & & & & & & & \\
\hline & CBS $221.81 *$ & 55 & 47 & 5 & - & GU227953 & GU228149 & - & - & - & - & - & - \\
\hline \multirow{2}{*}{ C. citri } & & KC2935 & KC2937 & & & & & KC29370 & KC2937 & & & & \\
\hline & ZJUC41* & 81 & 41 & - & - & KC293621 & KC293661 & 1 & 81 & - & - & - & - \\
\hline \multirow{2}{*}{ C. citricola } & & KC2935 & KC2937 & & & & & KC29369 & KC2937 & & & & \\
\hline & $\mathrm{SXC} 151 *$ & 76 & 36 & KC293792 & - & KC293616 & KC293656 & 6 & 76 & - & - & - & - \\
\hline \multirow{2}{*}{ C. clidemiae } & & JX01026 & JX00998 & & & & & & JX01012 & JX01035 & KC88892 & & \\
\hline & ICMP 18658* & 5 & 9 & JX009877 & - & JX009537 & JX010438 & JX009645 & 9 & 6 & 9 & - & - \\
\hline \multirow{2}{*}{ C. cliviae } & & GQ4856 & GQ8567 & GQ85672 & & & & & & & & & \\
\hline & CBS $125375^{*}$ & 07 & 56 & 2 & - & GQ856777 & GQ849440 & - & - & - & - & - & - \\
\hline \multirow{2}{*}{ C.coccodes } & & HM1716 & HM1716 & & & HM17166 & & & & & & & \\
\hline & CBS $369.75^{*}$ & 79 & 73 & JX546681 & - & 7 & JX546873 & - & - & - & - & - & - \\
\hline \multirow{2}{*}{ C. colombiense } & & JQ00517 & JQ00526 & & & & & & & & & & \\
\hline & CBS 129818* & 4 & 1 & JQ005348 & JQ005435 & JQ005522 & JQ005608 & JQ005695 & - & - & - & - & - \\
\hline \multirow{2}{*}{ C. conoides } & & KP89016 & KP89016 & & & & & & & & & & \\
\hline & CAUG17* & 8 & 2 & KP890156 & - & KP890144 & KP890174 & KP890150 & - & - & - & - & - \\
\hline \multirow{2}{*}{ C. constrictum } & & JQ00523 & JQ00532 & & & & & & & & & & \\
\hline & CBS $128504 *$ & 8 & 5 & JQ005412 & JQ005499 & JQ005586 & JQ005672 & JQ005759 & - & - & - & - & - \\
\hline \multirow{2}{*}{ C. cordylinicola } & & JX01022 & JX00997 & & & HM47023 & & HM47023 & JX01012 & JX01036 & & & \\
\hline & ICMP 18579* & 6 & 5 & JX009864 & - & 5 & JX010440 & 8 & 2 & 1 & JQ899274 & - & - \\
\hline \multirow{2}{*}{ C. cosmi } & & JQ94827 & JQ94860 & & & & & & & & & & \\
\hline & CBS 853.73* & 4 & 4 & JQ948935 & JQ949265 & JQ949595 & JQ949925 & - & - & - & - & - & - \\
\hline \multirow{2}{*}{ C. costaricense } & & JQ94818 & JQ94851 & & & & & & & & & & \\
\hline & CBS 330.75* & 1 & 1 & JQ948842 & JQ949172 & JQ949502 & JQ949832 & - & - & - & - & - & - \\
\hline \multirow{2}{*}{ C. curcumae } & & $\begin{array}{l}\text { GU2278 } \\
93\end{array}$ & GU2282 & GU22838 & & & & & & & & & \\
\hline & IIMI $28893 / *$ & 93 & 85 & 3 & GU228089 & GU221991 & GU22818/ & - & - & - & - & - & - \\
\hline C. cuscutae & IMI $304802 *$ & JQ94819 & JQ94852 & JQ948856 & JQ949186 & JQ949516 & JQ949846 & - & - & - & - & - & - \\
\hline
\end{tabular}




\begin{tabular}{|c|c|c|c|c|c|c|c|c|c|c|c|c|c|}
\hline \multirow[t]{2}{*}{ Species Name } & \multirow[t]{2}{*}{ Isolate No } & \multicolumn{12}{|c|}{ GenBank Accession Numbers } \\
\hline & & ITS & GAPDH & CHS-1 & HIS3 & ACT & TUB2 & CAL & GS & SOD2 & ApMat & Apn2 & Mat1 \\
\hline & & 5 & 5 & & & & & & & & & & \\
\hline C. cymbidiicola & IMI $347923 *$ & $\begin{array}{l}\text { JQ00516 } \\
6\end{array}$ & $\begin{array}{l}\text { JQ00525 } \\
3\end{array}$ & JQ005340 & JQ005427 & JQ005514 & JQ005600 & JQ005687 & - & - & - & - & - \\
\hline C. dacrycarpi & CBS 130241* & $\begin{array}{l}\text { JQ00523 } \\
6\end{array}$ & $\begin{array}{l}\text { JQ00532 } \\
3\end{array}$ & JO005410 & JO005497 & JO005584 & JO005670 & JO005757 & - & - & & & \\
\hline C. dematium & CBS $125.25^{*}$ & $\begin{array}{l}\text { GU2278 } \\
19\end{array}$ & $\begin{array}{l}\text { GU2282 } \\
11\end{array}$ & $\begin{array}{l}\text { GU22830 } \\
9\end{array}$ & GU228015 & GU227917 & GU228113 & - & - & - & - & - & - \\
\hline C. destructivum & CBS $136228^{*}$ & $\begin{array}{l}\text { KM1052 } \\
07\end{array}$ & $\begin{array}{l}\text { KM1055 } \\
61\end{array}$ & $\begin{array}{l}\text { KM10527 } \\
7\end{array}$ & KM105347 & $\begin{array}{l}\text { KM10541 } \\
7\end{array}$ & KM105487 & - & - & - & - & - & - \\
\hline $\begin{array}{l}\text { C. } \\
\text { dracaenophilum }\end{array}$ & CBS $118199 *$ & $\begin{array}{l}\text { JX51922 } \\
2\end{array}$ & $\begin{array}{l}\text { JX54670 } \\
7\end{array}$ & JX519230 & - & JX519238 & JX519247 & - & - & - & - & - & - \\
\hline C. duyunensis & $\begin{array}{l}\text { CGMCC } \\
3.15105^{*}\end{array}$ & $\begin{array}{l}\text { JX62516 } \\
0\end{array}$ & $\begin{array}{l}\text { KC } 8435 \\
15\end{array}$ & - & - & KC843530 & JX625187 & - & - & - & - & - & - \\
\hline C. echinochloae & MAFF 511473* & $\begin{array}{l}\text { AB4398 } \\
11\end{array}$ & - & - & - & - & - & - & - & - & - & - & - \\
\hline C. eleusines & MAFF 511155* & $\begin{array}{l}\text { JX51921 } \\
8\end{array}$ & - & - & - & JX519234 & JX519243 & - & - & - & - & - & - \\
\hline C. endophytica & $\begin{array}{l}\text { MFLUCC 13- } \\
0418^{*}\end{array}$ & $\begin{array}{l}\text { KC6338 } \\
54\end{array}$ & $\begin{array}{l}\text { KC } 8328 \\
54\end{array}$ & - & - & KF306258 & - & $\begin{array}{l}\text { KC81001 } \\
8\end{array}$ & - & - & - & - & - \\
\hline C. endophytum & $\begin{array}{l}\text { CGMCC } \\
3.15108^{*}\end{array}$ & $\begin{array}{l}\text { JX62517 } \\
7\end{array}$ & $\begin{array}{l}\text { KC } 8435 \\
21\end{array}$ & - & - & KC843533 & JX625206 & - & - & - & - & - & - \\
\hline C. eremochloae & CBS 129661* & $\begin{array}{l}\text { JX51922 } \\
0\end{array}$ & - & - & - & JX519236 & JX519245 & - & - & - & - & - & - \\
\hline C. euphorbiae & CBS $134725^{*}$ & $\begin{array}{l}\text { KF77714 } \\
6\end{array}$ & $\begin{array}{l}\text { KF77713 } \\
1\end{array}$ & KF777128 & KF777134 & KF777125 & KF777247 & - & - & - & - & - & - \\
\hline $\begin{array}{l}\text { C. excelsum- } \\
\text { altitudum }\end{array}$ & $\begin{array}{l}\text { CGMCC } \\
3.15130 *\end{array}$ & $\begin{array}{l}\text { HM7518 } \\
15\end{array}$ & $\begin{array}{l}\mathrm{KC} 8435 \\
02\end{array}$ & - & - & KC 843548 & JX625211 & - & - & - & - & - & - \\
\hline
\end{tabular}




\begin{tabular}{|c|c|c|c|c|c|c|c|c|c|c|c|c|c|}
\hline \multirow[t]{2}{*}{ Species Name } & \multirow[t]{2}{*}{ Isolate No } & \multicolumn{12}{|c|}{ GenBank Accession Numbers } \\
\hline & & ITS & GAPDH & CHS-1 & HIS3 & $\mathrm{ACT}$ & TUB2 & CAL & GS & SOD2 & ApMat & Apn2 & Mat1 \\
\hline \multirow{2}{*}{ C. falcatum } & CBS $147945^{*}$ & JQ00577 & & & & & & & & & & & \\
\hline & & 2 & & JQ005793 & JQ005814 & JQ005835 & JQ005856 & - & - & - & - & - & - \\
\hline \multirow{2}{*}{ C. fioriniae } & & JQ94829 & JQ94862 & & & & & & & & & & \\
\hline & CBS $128517 *$ & 2 & 2 & JQ948953 & JQ949283 & JQ949613 & JQ949943 & - & - & - & - & - & - \\
\hline \multirow{2}{*}{ C. fructi } & & GU2278 & GU2282 & GU22833 & & & & & & & & & \\
\hline & CBS $346.37 *$ & 44 & 36 & 4 & - & GU227942 & GU228138 & - & - & - & - & - & - \\
\hline \multirow{2}{*}{ C. fructicola } & & JX01016 & JX01003 & & & & & & JX01009 & JX01032 & & & \\
\hline & ICMP $18581 *$ & 5 & 3 & JX009866 & - & FJ907426 & JX010405 & FJ917508 & 5 & 7 & JQ807838 & - & - \\
\hline \multirow{2}{*}{ C. fructivorum } & & JX14514 & & & & & & & & & & & \\
\hline & Coll1414 * & 5 & - & - & - & - & JX145196 & - & - & - & JX145300 & - & - \\
\hline \multirow{2}{*}{ C. fuscum* } & & KM1051 & KM1055 & KM10524 & & KM10538 & & & & & & & \\
\hline & CBS $133701 *$ & 74 & 24 & 4 & KM105314 & 4 & KM105454 & - & - & - & - & - & - \\
\hline \multirow{2}{*}{ C. fusiforme } & MFLUCC 12- & KT29026 & KT29025 & & & & & & & & & & \\
\hline & $0437 *$ & 6 & 5 & KT290253 & - & KT290251 & KT290256 & - & - & - & - & - & - \\
\hline \multirow{2}{*}{ C. gigasporum } & CBS $133266^{*}$ & KF68771 & KF68782 & & & & & & & & & & \\
\hline & & 5 & 2 & KF687761 & KF687844 & - & KF687866 & - & - & - & - & - & - \\
\hline \multirow{2}{*}{ C. gloeosporioides } & & JQ00515 & JQ00523 & & & & & & JX01008 & JX01036 & & & \\
\hline & CBS $112999 *$ & 2 & 9 & JQ005326 & JQ005413 & JQ005500 & JQ005587 & JQ005673 & 5 & 5 & JQ807843 & - & - \\
\hline C. godetiae & CBS $133.44 *$ & $\begin{array}{l}\text { JQ94840 } \\
2\end{array}$ & $\begin{array}{l}\text { JQ94873 } \\
3\end{array}$ & JQ949063 & JQ949393 & JQ949723 & JQ950053 & - & - & - & - & - & - \\
\hline \multirow{2}{*}{ C. graminicola } & & JQ00576 & & & & & & & & & & & \\
\hline & CBS 130836* & 7 & - & JQ005788 & - & JQ005830 & JQ005851 & - & - & - & - & - & - \\
\hline \multirow{2}{*}{ C. grevilleae } & & KC2970 & KC2970 & & & & & KC29696 & & & & & \\
\hline & CBS 132879* & 78 & 10 & KC296987 & - & KC296941 & KC297102 & 3 & - & - & - & - & - \\
\hline \multirow{2}{*}{ C. grossum } & & KP89016 & KP89015 & & & & & & & & & & \\
\hline & CAUG7* & 5 & 9 & KP890153 & - & KР890153 & KP890171 & KP890147 & - & - & - & - & - \\
\hline C. guajavae & IMI $350839 *$ & JQ94827 & JQ94860 & JQ948931 & JQ949261 & JQ949591 & JQ949921 & - & - & - & - & - & - \\
\hline
\end{tabular}




\begin{tabular}{|c|c|c|c|c|c|c|c|c|c|c|c|c|c|}
\hline \multirow[t]{2}{*}{ Species Name } & \multirow[t]{2}{*}{ Isolate No } & \multicolumn{12}{|c|}{ GenBank Accession Numbers } \\
\hline & & ITS & GAPDH & CHS-1 & HIS3 & $\mathrm{ACT}$ & TUB2 & CAL & GS & SOD2 & ApMat & Apn2 & Mat1 \\
\hline & & 0 & 0 & & & & & & & & & & \\
\hline \multirow{2}{*}{ C. guizhouensis } & CGMCC & JX62515 & KC8435 & & & & & & & & & & \\
\hline & $3.15112 *$ & 8 & 07 & - & - & KC843536 & JX625185 & - & - & - & - & - & - \\
\hline \multirow{2}{*}{ C. hanaui } & & JX51921 & & & & & & & & & & & \\
\hline & MAFF $3054042 *$ & 7 & - & JX519225 & - & - & JX519242 & - & - & - & - & - & - \\
\hline \multirow{2}{*}{ C. hebeiense } & MFLUCC13- & KF15686 & KF37749 & & & & & & & & & & \\
\hline & $0726 *$ & 3 & 5 & KF289008 & - & KF377532 & KF288975 & - & - & - & - & - & - \\
\hline C. hemerocallidis & CDLG5* & $\begin{array}{l}\text { JQ40000 } \\
5\end{array}$ & $\begin{array}{l}\text { JQ40001 } \\
2\end{array}$ & JQ399998 & - & JQ399991 & JQ400019 & KJ781319 & - & - & - & - & - \\
\hline \multirow{2}{*}{ C. henanense } & CGMCC & KJ95510 & KJ95481 & & & KM02325 & & & KJ95496 & & & & \\
\hline & $3.17354 *$ & 9 & 0 & - & - & 7 & KJ955257 & KJ954662 & 0 & - & KJ954524 & - & - \\
\hline \multirow{2}{*}{ C. higginsianum } & & KM1051 & KM1055 & KM10525 & & KM10539 & & & & & & & \\
\hline & IMI 349061* & 84 & 35 & 4 & KM105324 & 4 & KM105464 & - & - & - & - & - & - \\
\hline \multirow{2}{*}{ C. hippeastri } & GDo inco76 & JQ00523 & JQ00531 & & & & & & & & & & \\
\hline & CBS $125376^{*}$ & 1 & 8 & JQ005405 & $\mathrm{JQ005492}$ & $\mathrm{JQ} 005579$ & $J Q 005665$ & $J Q 005752$ & - & - & - & - & - \\
\hline \multirow{2}{*}{ C. horii } & & GQ3296 & GQ3296 & & & & & & JX01013 & JX01037 & & & \\
\hline & ICMP 10492* & 90 & 81 & JX009752 & - & JX009438 & JX010450 & JX009604 & 7 & 0 & JQ807840 & - & - \\
\hline \multirow[t]{2}{*}{ C. hsienjenchang } & MAFF 243051 & AB7388 & & D720046 & 10720017 & $1 \mathrm{D} 730045$ & & & & & & & \\
\hline & & & - & AD $/ 50040$ & AD/J004t & AD/J004J & - & - & - & - & - & - & - \\
\hline \multirow{2}{*}{$\begin{array}{l}\text { C. } \\
\text { hymenocallidicola }\end{array}$} & MFLUCC 12- & KT29026 & KT29026 & & & & & & & & & & \\
\hline & $0531 *$ & 4 & 3 & KT290262 & - & - & - & - & - & - & - & - & - \\
\hline \multirow{2}{*}{ C. incanum } & ATCC & KC1107 & KC1108 & & & & & & & & & & \\
\hline & AICC $64682 \%$ & 89 & 01 & - & КС110/98 & КС110825 & КС110816 & - & - & - & - & - & - \\
\hline \multirow{2}{*}{ C. indonesiense } & & JQ94828 & JQ94861 & & & & & & & & & & \\
\hline & CBS $127551 *$ & 8 & 8 & JQ948949 & JQ949279 & JQ949609 & JQ949939 & - & - & - & - & - & - \\
\hline \multirow[t]{2}{*}{ C. jacksonii } & & JX51921 & & IY510224 & & & & & & & & & \\
\hline & MAFF $3054602^{*}$ & 6 & - & JX519224 & - & JX519233 & JX519241 & - & - & - & - & - & - \\
\hline
\end{tabular}




\begin{tabular}{|c|c|c|c|c|c|c|c|c|c|c|c|c|c|}
\hline \multirow[t]{2}{*}{ Species Name } & \multirow[t]{2}{*}{ Isolate No } & \multicolumn{12}{|c|}{ GenBank Accession Numbers } \\
\hline & & ITS & GAPDH & CHS-1 & HIS3 & $\mathrm{ACT}$ & TUB2 & CAL & GS & SOD2 & ApMat & Apn2 & Mat1 \\
\hline \multirow{2}{*}{ C. jasiminigenum } & MFLUCC 10- & HM1315 & HM1314 & & & HM13150 & & & & & & & \\
\hline & $0273 *$ & 13 & 99 & - & - & 8 & HM153770 & - & - & - & - & - & - \\
\hline \multirow{2}{*}{ C. jiangxiense } & CGMCC & KJ95520 & KJ95490 & & & & & & KJ95505 & & & & \\
\hline & $3.17363 *$ & 1 & 2 & - & - & KJ954471 & KJ955348 & KJ954752 & 1 & - & KJ954607 & - & - \\
\hline \multirow{2}{*}{ C. johnstonii } & & JQ94844 & JQ94877 & & & & & & & & & & \\
\hline & CBS $128532 *$ & 4 & 5 & JQ949105 & JQ949435 & JQ949765 & JQ950095 & - & - & - & - & - & - \\
\hline \multirow{2}{*}{ C. kahawae } & & JX01023 & JX01001 & & & & & & JX01013 & JX01035 & & & \\
\hline & ICMP $17816 *$ & 1 & 2 & JX009813 & - & JX009452 & JX010444 & JX009642 & 0 & 0 & JQ894579 & - & - \\
\hline \multirow{2}{*}{ C. karstii } & & JQ00520 & JQ00520 & & & & & & & & & & \\
\hline & CBS $127597 *$ & 4 & 4 & JQ005378 & JQ005465 & JQ005552 & JQ005638 & JQ005725 & - & - & - & - & - \\
\hline \multirow{2}{*}{ C. kinghornii } & & JQ94845 & JQ94878 & & & & & & & & & & \\
\hline & CBS $198.35^{*}$ & 4 & 5 & JQ949115 & JQ949445 & JQ949775 & JQ950105 & - & - & - & - & - & - \\
\hline \multirow{2}{*}{ C. lacticiphilum } & & JQ94828 & JQ94861 & & & & & & & & & & \\
\hline & CBS 112989* & 9 & 9 & JQ948950 & JQ949280 & JQ949610 & JQ949940 & - & - & - & - & - & - \\
\hline \multirow{2}{*}{ C. liaoningense } & & KP89010 & KP89013 & & & & & & & & & & \\
\hline & CAUOS2* & 4 & 5 & KP890127 & - & KP890097 & KP89011 & KP890119 & - & - & - & - & - \\
\hline \multirow{2}{*}{ C. lilii } & & GU2278 & GU2282 & & & & & & & & & & \\
\hline & CBS 109214 & 10 & 02 & - & - & GU227908 & GU228104 & - & - & - & - & - & - \\
\hline C. limetticola & CBS $114.14 *$ & $\begin{array}{l}\text { JQ94819 } \\
3\end{array}$ & $\begin{array}{l}\text { JQ94852 } \\
3\end{array}$ & JQ948854 & JQ949184 & JQ949514 & JQ949844 & - & - & - & - & - & - \\
\hline \multirow{2}{*}{$\begin{array}{l}\text { C. } \\
\text { lindemuthianum }\end{array}$} & & JQ00577 & JX54671 & & & & & & KF17864 & & & & \\
\hline & CBS $144.31 *$ & 9 & 2 & JQ005800 & JQ005821 & JQ005842 & JQ005863 & - & 3 & - & - & - & - \\
\hline \multirow{2}{*}{ C. lentis } & & JQ00576 & KM1055 & & & & & & & & & & \\
\hline & CBS 127604* & 6 & 97 & JQ005787 & JQ005808 & JQ005829 & JQ005850 & - & - & - & - & - & - \\
\hline \multirow{2}{*}{ C. ledebouriae } & & KX2282 & & & & & & & & & & & \\
\hline & CBS 141284* & 54 & - & - & KX228365 & KX228357 & - & - & - & - & - & - & - \\
\hline C. lineola & CBS $125337 *$ & GU2278 & GU2282 & GU22831 & - & GU227927 & GU228123 & - & - & - & - & - & - \\
\hline
\end{tabular}




\begin{tabular}{|c|c|c|c|c|c|c|c|c|c|c|c|c|c|}
\hline \multirow[t]{2}{*}{ Species Name } & \multirow[t]{2}{*}{ Isolate No } & \multicolumn{12}{|c|}{ GenBank Accession Numbers } \\
\hline & & ITS & GAPDH & CHS-1 & HIS3 & $\mathrm{ACT}$ & TUB2 & CAL & GS & SOD2 & ApMat & Apn2 & Mat1 \\
\hline & & 29 & 21 & 9 & & & & & & & & & \\
\hline C. lini & CBS $172.51 *$ & $\begin{array}{l}\text { JQ00576 } \\
5\end{array}$ & $\begin{array}{l}\text { KM1055 } \\
81\end{array}$ & JQ005786 & JQ005807 & JQ005828 & JQ005849 & - & - & - & - & - & - \\
\hline \multirow{2}{*}{ C. liriopes } & & GU2278 & GU2281 & GU22829 & & & & & & & & & \\
\hline & CBS $119444 *$ & 04 & 96 & 4 & - & GU227902 & GU228098 & - & - & - & - & - & - \\
\hline \multirow{2}{*}{ C. lupini } & & JQ94815 & JQ94848 & & & & & & & & & & \\
\hline & CBS $109225^{*}$ & 5 & 5 & JQ948816 & JQ949146 & JQ949476 & JQ949806 & - & - & - & - & - & - \\
\hline \multirow{2}{*}{ C. magnisporum } & & KF68771 & KF68784 & & & & & & KF68774 & & & & \\
\hline & CBS 398.84* & 8 & 2 & KF687782 & KF687865 & KF687803 & KF687882 & - & 2 & - & - & - & - \\
\hline \multirow{2}{*}{ C. malvarum } & & KF17848 & KF17850 & & & & & & KF17862 & & & & \\
\hline & CBS 521.97* & 0 & 4 & KF178529 & KF178553 & KF178577 & KF178601 & - & 6 & - & - & - & - \\
\hline \multirow{2}{*}{ C. melonis } & & JQ94819 & JQ94852 & & & & & & & & & & \\
\hline & CBS 159.84* & 4 & 4 & JQ948855 & JQ949185 & JQ949515 & JQ949845 & - & - & - & - & - & - \\
\hline \multirow{2}{*}{ C. menispermi } & MFLU 14- & KU2423 & KU2423 & KU24235 & & & & & & & & & \\
\hline & $0625 *$ & 57 & 56 & 5 & - & KU242353 & KU242354 & - & - & - & - & - & - \\
\hline C. metake & MAFF 244029* & $\begin{array}{l}\text { AB7388 } \\
59\end{array}$ & \multicolumn{11}{|c|}{ (Sequences availabe at http://www.gene.affrc.go.jp/databases-micro_search_en.php) } \\
\hline \multirow{2}{*}{ C. miscanthi } & & JX51922 & & & & & & & & & & & \\
\hline & MAFF 510857* & 1 & - & - & - & JX519237 & JX519246 & - & - & - & - & - & - \\
\hline \multirow{2}{*}{ C. musae } & & JX01014 & JX01005 & & & & & & JX01010 & JX01033 & KC88892 & & \\
\hline & ICMP 19119* & 6 & 0 & JX009896 & - & JX009433 & HQ596280 & JX009742 & 3 & 5 & 6 & - & - \\
\hline C. navitas & CBS $1250862 *$ & $\begin{array}{l}\text { JQ00576 } \\
9\end{array}$ & - & JQ005790 & JQ005811 & JQ005832 & JQ005853 & - & - & - & - & - & - \\
\hline$C$. & & KR4767 & KR4767 & & & & & & & & & & \\
\hline neosansevieriae & CBS 139918* & 47 & 91 & - & KR476792 & KR476790 & KR476797 & - & - & - & - & - & - \\
\hline C. nicholsonii & MAFF 5111152* & $\begin{array}{l}\text { JQ00577 } \\
0\end{array}$ & - & JQ005791 & JQ005812 & JQ005833 & JQ005854 & - & - & - & - & - & - \\
\hline
\end{tabular}




\begin{tabular}{|c|c|c|c|c|c|c|c|c|c|c|c|c|c|}
\hline \multirow[t]{2}{*}{ Species Name } & \multirow[t]{2}{*}{ Isolate No } & \multicolumn{12}{|c|}{ GenBank Accession Numbers } \\
\hline & & ITS & GAPDH & CHS-1 & HIS3 & ACT & TUB2 & CAL & GS & SOD2 & ApMat & Apn2 & Mat1 \\
\hline \multirow[b]{2}{*}{ C. nigrum } & & JX54683 & JX54674 & & & & & & & & & & \\
\hline & CBS $169.49^{*}$ & 8 & 2 & JX546693 & - & JX546646 & JX546885 & - & - & - & - & - & - \\
\hline \multirow{2}{*}{$\begin{array}{l}\text { C. novae- } \\
\text { zelandiae }\end{array}$} & & JQ00522 & JQ00531 & & & & & & & & & & \\
\hline & CBS $128505^{*}$ & 8 & 5 & JQ005402 & JQ005489 & JQ005576 & JQ005662 & JQ005749 & - & - & - & - & - \\
\hline \multirow{2}{*}{ C. nupharicola } & & JX01018 & JX00997 & & & & & & JX01008 & JX01032 & & & \\
\hline & CAVI $1010 \%$ & 7 & 2 & JX009835 & - & $J \Lambda 00943$ & JX010398 & JX009063 & 8 & 0 & - & - & - \\
\hline \multirow{2}{*}{ C. nymphaeae } & & JQ94819 & JQ94852 & & & & & & & & & & \\
\hline & CBS 515.78* & 7 & 7 & JQ948858 & JQ949188 & JQ949518 & JQ949848 & - & - & - & - & - & - \\
\hline \multirow{2}{*}{ C. ochracea } & CGMCC & JX62516 & KC8435 & & & & & & & & & & \\
\hline & $3.15104^{*}$ & 8 & 13 & - & - & KC843527 & JX625183 & - & - & - & - & - & - \\
\hline \multirow{2}{*}{ C. ocimi } & & KM1052 & KM1055 & KM10529 & & & & & & & & & \\
\hline & CBS 298.94* & 22 & 77 & 2 & KM105362 & KM105432 & KM105502 & - & - & - & - & - & - \\
\hline \multirow{2}{*}{ C. oncidii } & & JQ00516 & JQ00525 & & & & & & & & & & \\
\hline & CBS $129828 *$ & 9 & 6 & JQ005343 & JQ005430 & JQ005517 & JQ005603 & JQ005690 & - & - & - & - & - \\
\hline \multirow{2}{*}{ C. orbiculare } & & KF17846 & KF17849 & & & & & & KF17861 & & & & \\
\hline & CBS 570.97* & 6 & 0 & KF178515 & KF178539 & KF178563 & KF178587 & - & 1 & - & - & - & - \\
\hline \multirow{2}{*}{ C. orchidophilum } & & JQ94815 & JQ94848 & & & & & & & & & & \\
\hline & CBS 632.80* & 1 & 1 & JQ948812 & JQ949142 & JQ949472 & JQ949802 & - & - & - & - & - & - \\
\hline \multirow{3}{*}{ C. panacicola } & & GU9358 & GU9358 & & & & & & & & & & \\
\hline & C08048 & 67 & 47 & - & - & - & - & - & - & - & - & - & - \\
\hline & & КС2049 & KC2050 & KC20504 & & & & & & & & & \\
\hline C. paranaense & CBS $134729 *$ & 92 & 26 & 3 & KC205004 & KC205077 & KC205060 & - & - & - & - & - & - \\
\hline C. parsonsiae & & JQ00523 & JQ00532 & & & & & & & & & & \\
\hline & CBS $128525 *$ & 3 & 0 & $J Q 005407$ & JQ005494 & JQ005581 & JQ005667 & JQ005754 & - & - & - & - & - \\
\hline C. paspali & MAFF $3054032 *$ & $\begin{array}{l}\text { JX51921 } \\
9\end{array}$ & - & JX519227 & - & JX519235 & JX519244 & - & - & - & - & - & - \\
\hline C. paxtonii & IMI 165753* & JO94828 & JO94861 & JQ948946 & JQ949276 & JQ949606 & JQ949936 & - & - & - & - & - & - \\
\hline
\end{tabular}




\begin{tabular}{|c|c|c|c|c|c|c|c|c|c|c|c|c|c|}
\hline \multirow[t]{2}{*}{ Species Name } & \multirow[t]{2}{*}{ Isolate No } & \multicolumn{12}{|c|}{ GenBank Accession Numbers } \\
\hline & & ITS & GAPDH & CHS-1 & HIS3 & $\mathrm{ACT}$ & TUB2 & CAL & GS & SOD2 & ApMat & Apn2 & Mat1 \\
\hline & & 5 & 5 & & & & & & & & & & \\
\hline C. petchii & CBS $378.94 *$ & $\begin{array}{l}\text { JQ00522 } \\
3\end{array}$ & $\begin{array}{l}\text { JQ00531 } \\
0\end{array}$ & JQ005397 & JQ005484 & JQ005571 & JQ005657 & JQ005744 & - & - & - & - & - \\
\hline C. phormii & CBS $118194 *$ & $\begin{array}{l}\text { JQ94844 } \\
6\end{array}$ & $\begin{array}{l}\text { JQ94877 } \\
7\end{array}$ & JQ949107 & JQ949437 & JQ949767 & JQ950097 & - & - & - & - & - & - \\
\hline C. phyllanthi & CBS $175.67 *$ & $\begin{array}{l}\text { JQ00522 } \\
1\end{array}$ & $\begin{array}{l}\text { JQ00530 } \\
8\end{array}$ & JQ005395 & JQ005482 & JQ005569 & JQ005655 & JQ005742 & - & - & - & - & - \\
\hline C. pisicola & CBS 724.97* & $\begin{array}{l}\text { KM1051 } \\
72\end{array}$ & $\begin{array}{l}\text { KM1055 } \\
22\end{array}$ & $\begin{array}{l}\text { KM10524 } \\
2\end{array}$ & KM105312 & KM105382 & KM105452 & - & - & - & - & - & - \\
\hline C. proteae & CBS $132882 *$ & $\begin{array}{l}\mathrm{KC} 2970 \\
79\end{array}$ & $\begin{array}{l}\mathrm{KC} 2970 \\
09\end{array}$ & $\begin{array}{l}\text { KC29698 } \\
6\end{array}$ & - & KC296940 & KC297101 & $\begin{array}{l}\text { KC29696 } \\
0\end{array}$ & - & - & - & - & - \\
\hline $\begin{array}{l}\text { C. } \\
\text { pseudoacutatum }\end{array}$ & CBS $436.77 *$ & $\begin{array}{l}\text { JQ94848 } \\
0\end{array}$ & $\begin{array}{l}\text { JQ94881 } \\
1\end{array}$ & JQ949141 & JQ949471 & JQ949801 & JQ950131 & - & - & - & - & - & - \\
\hline C. pseudomajus & CBS 571.88* & $\begin{array}{l}\text { KF68772 } \\
2\end{array}$ & $\begin{array}{l}\text { KF68782 } \\
6\end{array}$ & KF687779 & KF687864 & KF687801 & KF687883 & KF687807 & $\begin{array}{l}\text { KF68774 } \\
4\end{array}$ & - & - & - & - \\
\hline C. psidii & ICMP $19120 *$ & $\begin{array}{l}\text { JX01021 } \\
9\end{array}$ & $\begin{array}{l}\text { JX00996 } \\
7\end{array}$ & JX009901 & - & JX009515 & JX010443 & JX009743 & $\begin{array}{l}\text { JX01013 } \\
3\end{array}$ & $\begin{array}{l}\text { JX01036 } \\
6\end{array}$ & $\begin{array}{l}\mathrm{KC} 88893 \\
1\end{array}$ & - & - \\
\hline C. pyricola & CBS $128531 *$ & $\begin{array}{l}\text { JQ94844 } \\
5\end{array}$ & $\begin{array}{l}\text { JQ94877 } \\
6\end{array}$ & JQ949106 & JQ949436 & JQ949766 & JQ950096 & - & - & - & - & - & - \\
\hline $\begin{array}{l}\text { C. } \\
\text { queenslandicum }\end{array}$ & ICMP $1778 *$ & $\begin{array}{l}\text { JX01027 } \\
6\end{array}$ & $\begin{array}{l}\text { JX00993 } \\
4\end{array}$ & JX009899 & - & JX009447 & JX010414 & JX009691 & $\begin{array}{l}\text { JX01010 } \\
4\end{array}$ & $\begin{array}{l}\text { JX01033 } \\
6\end{array}$ & $\begin{array}{l}\text { KC } 88892 \\
8\end{array}$ & - & - \\
\hline C. quinquefoliae & $\begin{array}{l}\text { MFLU 14- } \\
0626 *\end{array}$ & $\begin{array}{l}\text { KU2363 } \\
91\end{array}$ & $\begin{array}{l}\text { KU2363 } \\
90\end{array}$ & - & - & KU236389 & KU236392 & - & - & - & - & - & - \\
\hline C. radicis & CBS 529.93* & $\begin{array}{l}\text { KF68771 } \\
9\end{array}$ & $\begin{array}{l}\text { KF68782 } \\
5\end{array}$ & KF687762 & KF687847 & KF687785 & KF687869 & KF687806 & $\begin{array}{l}\text { KF68774 } \\
3\end{array}$ & - & - & - & - \\
\hline C. rhombiforme & CBS $129953 *$ & $\begin{array}{l}\text { JQ94845 } \\
7\end{array}$ & $\begin{array}{l}\text { JQ94878 } \\
8\end{array}$ & JQ949118 & JQ949448 & JQ949778 & JQ950108 & - & - & - & - & - & - \\
\hline
\end{tabular}




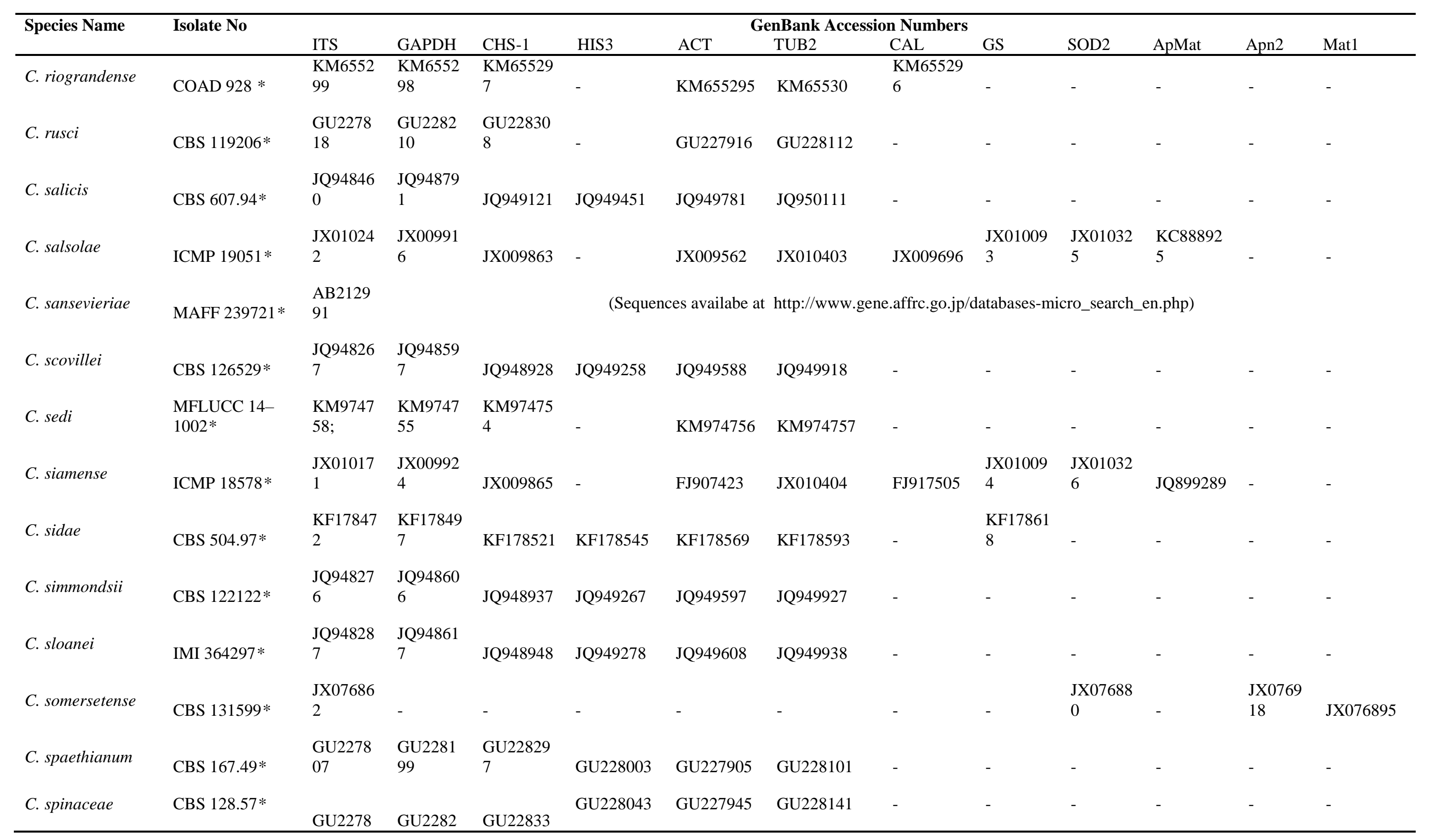




\begin{tabular}{|c|c|c|c|c|c|c|c|c|c|c|c|c|c|}
\hline \multirow[t]{2}{*}{ Species Name } & \multirow[t]{2}{*}{ Isolate No } & \multicolumn{12}{|c|}{ GenBank Accession Numbers } \\
\hline & & ITS & GAPDH & CHS-1 & HIS3 & $\mathrm{ACT}$ & TUB2 & CAL & GS & SOD2 & ApMat & Apn2 & Mat1 \\
\hline & & 47 & 39 & 7 & & & & & & & & & \\
\hline \multirow{2}{*}{ C. spinosum } & & KF17847 & KF17849 & & & & & & KF17862 & & & & \\
\hline & CBS $515.97 *$ & 4 & 8 & KF178523 & KF178547 & KF178571 & KF178595 & - & 0 & - & - & - & - \\
\hline \multirow{2}{*}{ C. sublineola } & & JQ00577 & & & & & & & & & & & \\
\hline & CBS $131301 *$ & 1 & - & JQ005792 & JQ005813 & JQ005834 & JQ005855 & - & - & - & - & - & - \\
\hline \multirow{2}{*}{ C. syzygicola } & MFLUCC10- & KF24209 & KF24215 & & & & & & & & & & \\
\hline & $0624 *$ & 4 & 6 & - & - & KF157801 & KF254880 & KF254859 & - & - & - & - & - \\
\hline \multirow{2}{*}{ C. tabacum } & & KM1052 & KM1055 & KM10527 & & & & & & & & & \\
\hline & СРС $18945^{*}$ & 04 & 57 & 4 & KM105344 & KM105414 & KM105484 & - & - & - & - & - & - \\
\hline C. tamarilloi & CBS 129814* & $\begin{array}{l}\text { JQ94818 } \\
4\end{array}$ & $\begin{array}{l}\text { JQ94851 } \\
4\end{array}$ & JQ948845 & JQ949175 & JQ949505 & JQ949835 & - & - & - & - & - & - \\
\hline \multirow{2}{*}{ C. tanaceti } & & JX21822 & JX21824 & & & & & & & & & & \\
\hline & CBS $132693 *$ & 8 & 3 & JX259268 & - & JX218238 & JX218233 & - & - & - & - & - & - \\
\hline \multirow{2}{*}{ C. tebeestii } & & KF17847 & KF17850 & & & & & & KF17861 & & & & \\
\hline & CBS 522.97* & 3 & 5 & KF178522 & KF178546 & KF178570 & KF178594 & - & 9 & - & - & - & - \\
\hline \multirow{2}{*}{ C. temperatum } & & JX14515 & & & & & & & & & & & \\
\hline & Coll883 * & 9 & - & - & - & - & JX145211 & - & - & - & JX145298 & - & - \\
\hline \multirow{2}{*}{ C. theobromicola } & & JX01029 & JX01000 & & & & & & JX01013 & JX01037 & KC79072 & & \\
\hline & ICMP 18649* & 4 & 6 & JX009869 & - & JX009444 & JX010447 & JX009591 & 9 & 2 & 6 & - & - \\
\hline \multirow{2}{*}{ C. $t i$} & & JX01026 & JX00995 & & & & & & JX01012 & JX01036 & KM36014 & & \\
\hline & ICMP $4832 *$ & 9 & 2 & JX009898 & - & JX009520 & JX010442 & JX009649 & 3 & 2 & 6 & - & - \\
\hline \multirow{2}{*}{ C. tofieldiae } & & GU2278 & GU2281 & GU22829 & & & & & & & & & \\
\hline & CBS 495.85 & 01 & 93 & 1 & - & GU227899 & GU228095 & - & - & - & - & - & - \\
\hline \multirow{2}{*}{ C. torulosum } & & JQ00516 & JQ00525 & & & & & & & & & & \\
\hline & CBS 128544* & 4 & 1 & JQ005338 & JQ005425 & JQ005512 & JQ005512 & JQ005512 & - & - & - & - & - \\
\hline \multirow{2}{*}{ C. trichellum } & & GU2278 & GU2282 & GU22830 & & & & & & & & & \\
\hline & CBS 217.64* & 12 & 04 & 2 & - & GU227910 & GU228106 & - & - & - & - & - & - \\
\hline
\end{tabular}




\begin{tabular}{|c|c|c|c|c|c|c|c|c|c|c|c|c|c|}
\hline \multirow[t]{2}{*}{ Species Name } & \multirow[t]{2}{*}{ Isolate No } & \multicolumn{12}{|c|}{ GenBank Accession Numbers } \\
\hline & & ITS & GAPDH & CHS-1 & HIS3 & $\mathrm{ACT}$ & TUB2 & CAL & GS & SOD2 & ApMat & Apn2 & Mat1 \\
\hline \multirow{2}{*}{ C. trifolii } & & KF17847 & KF17850 & & & & & & KF17862 & & & & \\
\hline & CBS $158.83 *$ & 8 & 2 & KF178527 & KF178551 & KF178575 & KF178599 & - & 4 & - & - & - & - \\
\hline \multirow{2}{*}{ C. tropicale } & & JX01026 & JX01000 & & & & & & JX01009 & JX01032 & КC79072 & & \\
\hline & ICMP $18653 *$ & 4 & 7 & JX009870 & - & JX009489 & JX010407 & JX009719 & 7 & 9 & 8 & - & - \\
\hline \multirow{2}{*}{ C. tropicicola } & & JN05024 & JN05022 & & & & & & & & & & \\
\hline & LC0598* & 0 & 9 & - & - & JN050218 & JN050246 & - & - & - & - & - & - \\
\hline \multirow{2}{*}{ C. truncatum } & & GU2278 & GU2282 & GU22835 & & & & & & & & & \\
\hline & CBS $151.35^{*}$ & 62 & 54 & 2 & - & GU227960 & GU228156 & - & - & - & - & - & - \\
\hline \multirow{2}{*}{ C. utrechtense } & & KM1052 & KM1055 & KM10527 & & & & & & & & & \\
\hline & CBS $130243 *$ & 01 & 54 & 1 & KM105341 & KM105411 & KM105481 & - & - & - & - & - & - \\
\hline \multirow{2}{*}{ C. verruculosum } & & GU2278 & GU2281 & GU22829 & & & & & & & & & \\
\hline & IMI 45525* & 06 & 98 & 6 & - & GU227904 & GU228100 & - & - & - & - & - & - \\
\hline \multirow{2}{*}{ C. vietnamense } & & KF68772 & KF68783 & & & & & & KF68775 & & & & \\
\hline & CBS $125478 *$ & 1 & 2 & KF687769 & KF687855 & KF687792 & KF687877 & KF687816 & 3 & - & - & - & - \\
\hline \multirow{2}{*}{ C. vignae } & & KM1051 & KM1051 & KM10525 & & & & & & & & & \\
\hline & CBS 501.97* & 83 & 83 & 3 & KM105323 & KM105393 & KM105463 & - & - & - & - & - & - \\
\hline \multirow{3}{*}{ C. viniferum } & GZAAS5.08601 & JN41280 & JN41279 & & & & & & & & & & \\
\hline & $*$ & 4 & 8 & - & - & JN412795 & JN412813 & JQ309639 & - & - & - & - & - \\
\hline & $\begin{array}{l}\text { GZAAS5.08608 } \\
*\end{array}$ & - & - & - & - & - & - & - & - & - & KJ623242 & - & - \\
\hline & CGMCC & KU2515 & KU2520 & KU25193 & & & & KU25183 & KU2521 & & KU25172 & & \\
\hline C. wuxiense & $3.17894 *$ & 91 & 45 & 9 & - & KU251672 & KU252200 & 3 & 01 & - & 2 & - & - \\
\hline C. walleri & CBS $125472 *$ & $\begin{array}{l}\text { JQ94827 } \\
5\end{array}$ & $\begin{array}{l}\text { JQ94860 } \\
5\end{array}$ & JQ948936 & JQ949266 & JQ949596 & JQ949926 & - & - & - & - & - & - \\
\hline \multirow{2}{*}{ C. xanthorrhoeae } & & JX01026 & JX00992 & & & & & & JX01013 & JX01036 & KC79068 & & \\
\hline & ICMP 17903* & 1 & 7 & JX009823 & - & - & JX010448 & JX009653 & 8 & 9 & 9 & - & - \\
\hline C. yunnanense & CBS $132135 *$ & JX54680 & JX54670 & JX519231 & - & - & JX519248 & - & - & - & - & - & - \\
\hline
\end{tabular}




\begin{tabular}{|c|c|c|c|c|c|c|c|c|c|c|c|c|c|}
\hline \multirow{2}{*}{ Species Name } & \multirow{2}{*}{ Isolate No } & \multicolumn{12}{|c|}{ GenBank Accession Numbers } \\
\hline & & ITS & GAPDH & CHS-1 & HIS3 & $\mathrm{ACT}$ & TUB2 & CAL & GS & SOD2 & ApMat & Apn2 & Mat1 \\
\hline & & 4 & 6 & & & & & & & & & & \\
\hline C. zoysia & MAFF 2385732* & $\begin{array}{l}\text { JX07687 } \\
1\end{array}$ & - & - & - & - & - & - & - & - & - & $\begin{array}{l}\text { JX0769 } \\
22\end{array}$ & JX076899 \\
\hline
\end{tabular}

ATCC: American Type Culture Collection; BCC: BIOTEC Culture Collection, National Center for Genetic Engineering and Biotechnology (BIOTEC), Khlong Luang, Pathumthani, Thailand; BRIP: Plant Pathology Herbarium, Department of Employment, Economic, Development and Innovation, Queensland, Australia; CBS: Culture collection of the Centraalbureau voor Schimmelcultures, Fungal Biodiversity Centre, Utrecht, The Netherlands; CGMCC: China General Microbiological Culture Collection; COAD: Coleção Octávio Almeida Drummond, Viçosa, Brazil; CPC: Working collection of Pedro W. Crous, housed at CBS; IMI: Culture collection of CABI Europe UK Centre, Egham, UK; LC: Working collection of Lei Cai, housed at CAS, China; MAFF: MAFF GeneBank Project, Ministry of Agriculture, Forestry and Fisheries, Tsukuba, Japan; MFLUCC: Mae Fah Luang University Culture Collection, Chiang Rai, Thailand; MFLU: Herbarium of Mae Fah Luang University, Chiang Rai, Thailand; ICMP: International Collection of Microorganisms from Plants, Auckland, New Zealand; NBRC: Culture Collection of the Biological Resource Center, National Institute of Technology and Evaluation, Kisarazu, Japan. * ex-type strains. 